\title{
FISHES OF THE EASTERN PART OF THE INDO-AUSTRALIAN ARCHIPELAGO WITH REMARKS ON ITS ZOOGEOGRAPHY \\ BY
}

\section{$D^{R}$. L. F. DE BEAUFOR'T, EERBEEK.}

(With Plate II and 8 figures in the text). 


\title{
PRAEDA ITINERIS
}

a L. F. de Beaufort in Archipelago indico facti

annis 1909-1910.

X.

\section{Fishes of the eastern part of the Indo-Australian Archipelago with remarks on its zoogeography}

BY

\author{
DR. L. F. DE BEAUFORT, \\ EERBEEK.
}

(With Plate II and 8 figures in the text).

\begin{abstract}
'I'he collection of fishes, brought together during my voyage in the eastern part of the Indo-Australian Archipelago in 1909-1910, consists of about $1 \% 00$ specimens belonging to nearly $2 \% 0$ species, of which 9 were apparently new to science. $\%$ of these I have described previously, viz.: Rhombatractus catherinae in: Zool. Anz. XXXVI. p. 250, while the following gobies have been described in: Zool. Anz. XXXIX. p. 136: Gobius (Cryptocentrus) stigmatophorus, Gobius (Rhinogobius) scapulopunctatus, Schismatogobius bruynisi, Sicyopus multisquamatus, Sicyopterus brevis, Sicyopterus longifilis.

Doryrolımphus brevidorsalis and Gobius oyensi are described here for the first time.

By far the greater part of the fishes were collected by my wife and myself, but valuable additions were presented to me by Dr. P. Th. Justesen, at that time military surgeon at Buton, Messrs. M. J. van Baarda and G. A. Maan, missionaries at Halmahera, and Mr. L. de Bruyne, "posthouder" at Sorong, New Guinea. I hereby express my thanks to these gentlemen.

In working out these collections $I$ had not only the advantage of being able to consult Prof. Max Weber's manuscript on the fishes of the Siboga Expedition, but this able ichthyologist helped me most kindly, with many useful suggestions out of his rich experience, through which not a little was added to my ichthyological knowledge and I became better trained to collaborate to the work "Fishes of the Indo-Australian Archipelago", in which Prof. Weber and I are now engáged.

I am glad to have an opportunity of thanking my esteemed master for his help and friendship, which makes the prospect of our working together in coming years a pleasant one.

I will begin this paper with a systematic list of the species collected, and discuss in the sequal the fishfauna of the islands visited and its bearing upon the zoogeography of that part of the Indo-Australian Archipelago.

In the systematic part the literature is only quoted so far, as to leave no doubt which species is meant. Only in critical cases the literature is given more fully.
\end{abstract}




\section{Systematic part.}

\section{ELASMOBRANCHII \\ SELACHII}

Chiloscyllium Müller \& Henle.

1. Chiloscyllium freycineti (Q. G.)

Scyllium freycineti Quoy et Gaimard, Voy. Uranie, Poiss. p. 192.

Scyllium malaisianum Lesson, Voy. Coquille, Zool. II p. 94.

3 spec. 210-4\%0 mm, from Saonek, Dec. 1909, January 1910.

This species is only known from the specimens described by the above named authors from Waigeu. Bleeker recorded Ch. malayanum from Batjan and Java, but Günther (Cat. Brit. Mus. VIII p. 412 and 413) proved that Bleeker's specimens were Ch. indicum (Gm. L.) and punctatum M. H. As has already been stated by Günther (1. c. p. 411), Ch. freycineti is closely allied to $\mathrm{Ch}$. occellatum (Gm. L.) and Ch. trispeculare Rich. from Australia, differing from these species by the absence of a black, white-edged ocellus above the pectoral. In my specimens there are two dark brown spots, much darker than those on the body, above that fin, but they are not edged with white. These spots are not shown in the figure given by Lesson, which is otherwise correct, except in the outlines and position of the gill-slits. In my specimens the fourth and fifth slits are close together as in the other members of the genus. The second slit is wider than the first one, which is much wider than the orbit. According to Richardson's figure of Ch. trispeculare the upper border of the dorsal fin is more concave in $C h$. freycineti, forming a very acute angle with the hindborder, specially in the larger specimen, as is also described by Quoy \& Gaimard and figured by Lesson. The lip of the lower jaw is not continuous in the middle, as is also the case in the Australian species.

\section{TELEOSTOMI}

\section{Clupeidae}

Stolephorus Lac.

1. Stolephorus indicus (v. Hass.).

Engrautis indicus van Hasselt, Algem. Konst- en Letterbode 1823. p. 329.

Stolephorus indicus Bleeker, Atl. Ichth. VI p. 32.

Ambon, fishmarket, 3 spec. 96-69 mm, December \%. 1909.

3 spec. \%0-64 mm, February, 1910.

2. Stolephorus heterolobus Rüpp.

Stolephorus heterolobus Rüppell, Neue Wirbelt. Fische p. 79.

Stolephorus heterolobus Bleeker, Atl. Ichth. VI. p. 126.

4 spec. 60-64 mm, from the fishmarket at Buton, Dec. 3. 1909.

3. Stolephorus zollingeri (Blkr.).

Engraulis zollingeri Bleeker, Journ. Ind. Arch. II. p. 73.

Stolephorus zollingeri Bleeker, Atl. Ichth. VI. p. $12 \%$

2 spec. 58 and $70 \mathrm{~mm}$, from the fishmarket at Buton, Dec. 3. 1909. 
Clupea L.

1. Clupea (Harengula) atricauda Gthr.

Harengula melanurus Bleeker, Nat. Tijd. Ned. Ind. V p. 245 (nec C. V.).

Clupea atricauda Günther, Cat. Brit. Mus. VII p. 426.

Clupea (Harengula) atricauda Bleeker, Atl. Ichth. VI p. 106.

9 spec. 139-155 $\mathrm{mm}$, from Kairatu, W. Ceram. March 1, 1910.

2. Clupea (Harengula) moluccensis (Blkr.).

Harengula moluccensis Bleeker, Nat. Tijdschr. Ned. Indië IV p. 609.

Clupea (Harengula) moluccensis Bleeker, Atl. Ichth. VI p. $10 \%$.

Clupea (Harengula) kunzei Bleeker, Atl. Ichth. VI p. $10 \%$.

3 spec. 130-135 mm, Saonek, December 1909.

y spec. 52-132 mm, Ambon, January 1910.

2 spec. $120 \mathrm{~mm}$, Kairatu, W. Ceram, March ]. 1910.

3. Clupea (Harengula) schrammi (Blkr.).

Alosa schrammi Bleeker, Verh. Bat. Gen. XXII. Bijdr. ichth. Bali p. 11.

Clupea (Harengula) schrammi Bleeker, Atl. Ichth. VI p. 109.

2 spec. eirca $74 \mathrm{~mm}$ and $140 \mathrm{~mm}$, from the fishmarket at Ambon. December \%. 1909 and February 1910.

4. Clupea (Amblygaster) sirm Rüpp.

Clupea sirm Rüppell, Neue Wirbelth. Fische p. $\%$ \%

Sardinella leiogastroides Bleeker, Nat. Tijdschr. Ned. Indië VII p. 255.

Clupea (Amblygaster) leiogastroides Bleeker, Atl. Ichth. VI p. 102.

Clupea sirm Günther, Fische der Südsee, Heft VIII p. 383.

7 spec. circa 50-150 mm, Buton, fishmarket, December 3. 1909.

Siluridae

Paraplotosus Blkr.

Elongate, tail tapering, head depressed, mouth transverse, rounded in front. Lips thick, with papillae and vermiculated folds. Upper lip very prominent, perforated at its underside near the mouth opening by the anterior nostrils, which look downward and are surmounted anteriorly by a very prominent caniculated lip. Posterior nostril a slit between eye and upper lip, in front of which a nasal barbel. A supramaxillary barbel near the end of the upper lip, a mandibulary barbel below the corner of the mouth, two mental barbels between the mandibulary barbels. Eye not covered by skin. A short dorsal, beginning behind the origin of pectorals, with few rays and a strong spine. A long second dorsal, united with the caudal, and beginning before origin of ventrals. It is many-rayed as well as the long anal fin, which is also united with the caudal. Ventrals with 12-13 rays. Pectorals with a spine and 12-13 rays. Maxillary teeth conical, with rounded tips and arranged in two rhombic patches with rounded lateral edges. Inframaxillary ones in two aproximated semi-crescentic patches,

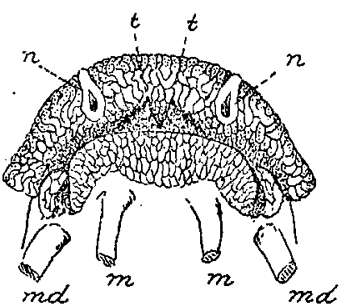

Fir. 1. View of the month and lips of Paraplotosus albilabris (C.V.) from below. $n$ nostril.

$t$ teeth.

md mandibnlary barbel.

$m$ mental barbel. the anterior row strong and conical, the posterior ones molars. Vomerine teeth molar, on a crescentic patch, the hindermost the stronger. First branchial arch with a finely crenulated membrane along the innerside of the horizontal branch, which bears 22 gillrakers. The second and third branchial arches with a series of long cartilaginous processes, covering the base of the gill-laminae on the sides facing each other. Gillmembranes confluent in the middle, 
only the anterior portion of their confluent part connected with the isthmus. Branchiostegals $9-11$. A very conspicuous dendritic organ between anus and anal.

The genus Paraplotosus was proposed by Bleeker for Plotosus albilabris C.V. with the

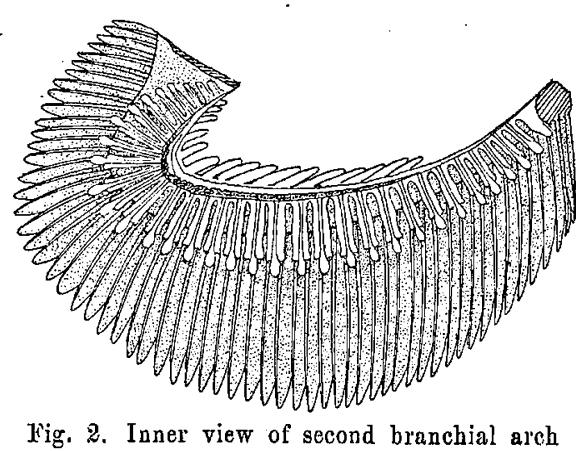

Tig. 2. Inner view of second branchial arch of Paraplotosus albilabris (C.V.). following words: „Cette espèce est remarquable par la position des narines dans la lèvre supérieure même au milieu des papilles labiales, par la disposition des dents intermaxillaires, par son profil très convexe et par la grandeur des yeux. L'ensemble de ces caractères pourrait bien conduire à $\mathrm{y}$ voir un genre distinct, qu'on pourrait nommer Paraplotosus". (Atl. Ichth. II p. 100).

Bleeker never gave a diagnosis of the genus and continued in his later papers to call the species Plotosus albilabris, as was done by most other authors.

Günther however (Cat. Brit. Mus. V p. 26) included this species in his genus Copidoglanis, although he says in the diagnosis of the genus: "nostrils as in Plotosus". He did so evidently on account of the presence of a membrane along the first branchial arch. By the pecular position of the anterior nostrils and by the presence of a dendritic organ behind the vent Paraplotosus is distinguished from the known species of Copidoglanis. By the last named character it approaches Plotosus and Cnidoglanis. It differs however from both genera by the position of the anterior nostrils; from Plotosus by the presence of cartilaginous processes on the second and third branchial arch and from Chidoglanis by the gillmembranes being free from the isthmus. Moreover it differs from Plotosus, with which genus it is most related, by the situation of the second dorsal fin, which originates before the origin of the ventrals and not behind it as in Plotosus.

1. Paraplotosus albilabris (C.V.).

Plotosus albilabris Cuvier \& Valenciennes, Hist. Nat. Poiss. XV p. $42 \%$.

Plotosus albilabris Bleeker, Atl. Ichth. II p. 99.

Copidoglanis albilabris Günther, Cat. Brit. Mus. V. p. 26.

One specimen, $340 \mathrm{~mm}$, from Sorong. New Guinea. Jan. 1910. (L. de Bruyne leg.)

1. Plotosus anguillaris (BI.).

$$
\text { Plotosus Lacépède. }
$$

Platystacus anguillaris. Bloch, Ausländ. Fische VIII p. 61.

Plotosus arab Bleeker, Atl. Ichth. II p. 98.

Plotosus anguillaris Günther, Cat. Brit. Mus. V p. 24.

2 spec. 82 and $87 \mathrm{~mm}$, Saonek. December 1909.

1 spec. $84 \mathrm{~mm}$, Sorong, New Guinea, L. de Bruyne leg.

5 spec. 65-70 mm, Buton, Dr. Justesen leg.

\section{Anguillidae.}

1. Anguilla celebesensis $\mathrm{Kp}$.

Genus Anguilla Cuvier.

Anguilla celebesensis Kaup, Cat. Apodal Fish, p. 42

Anguilla celebesensis Max Weber, Siboga-Exp. Fische, p. 39.

1 spec. $170 \mathrm{~mm}$. Upper course of the river Tuba, W. Ceram. February 2\%. 1910 (fresh water).

2. Anguilla mauritiana Benu.

Anguilla mauritiana Bennet,' Proc. Comm. Zool. Soc. London 1831 p. 128.

Anguilla mauritiana Max Weber, Siboga-Exp. Fische, p. $3 \%$.

One specimen, $810 \mathrm{~mm}$, from a river near Kajeli, Buru (fresh water). Dec. 9. 1909. 
3. Anguilla spec. juv.

1 spec. $69 \mathrm{~mm}$, River Waiu waigé, Waigeu, December 25. 1909.

5 spec. $45-60 \mathrm{~mm}$, River Waihå, Waigeu (fresh water).

$$
\text { Muraenichthys Bleeker. }
$$

1. Muraenichthys schultzei Blkr.

Muraenichthys schultzei Bleeker, Nat. Tijdschr. Ned. Ind. XIII p. 366. Atl. Ichth. IV p. 33.

Muraenichthys schultzei Günther. Cat. Brit. Mus. VIII p. 52.

Muraenichthys schultzei Day, Fishes of India $4^{\circ}$, p. 663.

One specimen, $75 \mathrm{~mm}$, from coralreef at Ambon. February 1910.

\section{Leiuranus Bleeker.}

1. Leiuranus semicinctus (Lay \& Benn.).

Ophisurus semicinctus Lay \& Bennett, Zool. Voy. Blossom. p. 66.

Leiuranus colubrinus Bleeker, Atl. Ichth. IV p. 43 (S. Syn.).

Liuranus semicinctus Günther, Cat. Brit. Mus. VIII p. 54.

Leiuranus semicinctus Jordan \& Snyder, Proc. U. S. Nat. Mus. XXIII p. 866.

Liuranus semicinctus Günther, Fische der Südsee. Heft IX p. 396.

One spec., $470 \mathrm{~mm}$, from Saonek, December 1909.

There are only 21 bands in my specimens, while normally this species has $25-35$ bands on body and tail. The 2 first bands on the head are irregularly connected along the sides of the head, the fourth and fifth band do not encircle the body as is the case with all the following bands, none of which are interrupted along the ventral side, as is commonly the case in this species.

I don't think that these differences are of any importance. It is known that the number of bands decreases with age (vide Bleeker l. c.).

1. Aphthalmichthys javanicus Kp.

$$
\text { Aphthalmichthys Kaup. }
$$

Aphthalmichthys javanicus Kaup, Arch. Naturg. XXII, I p. 68.

Aphthalmichthys javanicus Bleeker, Atl. Ichth. IV p. 16.

Moringua javanica Günther, Cat. Brit. Mus. VIII p. 92. Fische der Südsee, Heft IX p. 405.

One specimen, $2 \% 0 \mathrm{~mm}$, from the reef at Saonek, Jan. 21, 1910.

2. Aphthalmichthys abbreviatus Blkr.

Aphthalmichthys abbreviatus Bleeker, Ned. Tijschr. Dierk. I p. 163. Atl. Ichth. IV p. 17.

Moringua abbreviata Günther, Cat. Brit. Mus. VIII p. 92. Fische der Südsee, Heft IX p. 406.

Aphthalmichthys abbreviatus Jordan \& Snyder, Proc. U. S. Nat. Mus. XXIII p. 8\%.

Two specimens, 250 and $300 \mathrm{~mm}$, from the reef at Saonek, Dec. 1909 and Jan. 1910.

One Specimen, $195 \mathrm{~mm}$, from Ambon, March 1910.

The last named specimen has a shorter head, a little more than $1 / 10$ of the total length. As it is a young specimen, I don't doubt that it belongs to A. abbreviatus and not to $A$. macrocephalus, where the head is $1 \%$ of the total length, as Günther says l. c. „Die Länge des Kopfes is 12-13 mal, in jungen etwa 10\% mal in der Totallänge enthalten.".

$$
\text { Sphagebranchus Bloch, Schneider. }
$$

1. Sphagebranchus mindora (Jord. \& Rich.).

Caecula mindora Jordan \& Richardson, Bull. Bur. Fish. XXVII p. 239.

One specimen, $380 \mathrm{~mm}$, Waigeu, river Waiha, fresh water above rapids, Decemb. 20. 1909.

This species is related to Sphagebranchus macrodon Blkr, from which it differs in having a longer: snout, a smaller eye and a larger extent of the cleft of the mouth. 
Muraenidac.

Gy mothorax Bloch.

1. Gymnothorax brummeri (Blkr.).

Muraena Brummeri Bleeker, Nat. Tijdschr. Ned. Ind. XVII p. $13 \%$.

Strophidon Brummeri Bleeker, Atl. Ichtl. IV p. 109.

Strophidon polyodon Bleeker, Atl. Ichth. IV p. 109.

Muraena brummeri Günther, Fische der Südsee Heft IX p. 420.

One specimen, circa $550 \mathrm{~mm}$ long, from Ambon, February 1910.

My specimen quite agrees with Bleeker's description of Strophidon polyodon, but I think Günther is right in uniting this species with $S$. brummeri. I don't think there is reason to adopt the genus Strophidon as given by Bleeker, the only difference with Gymnothorax being the greater length of body and tail compared to height of body and length of head.

2. Gymnothorax richardsonii (Blkr.).

Muraena Richardsonii Bleeker, Nat. Tijdschr. Ned. Ind. IIJ p. 296.

Gymnothorax Richardsonii Bleeker, Atl. Ichth. IV p. 100.

Gymnothorax ceramensis Bleeker, Atl. Ichth. IV p. 101.

Muraena Richardsonii Günther, Fische der Südsee, Heft IX p. 414.

Three specimens, 100-350 mm, Saonek, reef, Dec. 1909.

3. Gymnothorax polyuranodon (Blkr.).

Muraena polyuranodon Bleeker, Nat. Tijd. Ned. Ind. V p. 248.

Gymnothorax polyuranodon Bleeker, Atl. Ichth. IV p. 89.

Muraena polyuranodon Günther, Cat. Brit. Mus. VIII p. 114, Fische der Südsee, Heft IX p. 421.

One specimen, $330 \mathrm{~mm}$, Batu merah, Ambon (brackish), February 1910.

4. Gymnothorax monochrous (Blkr.)?

Muraena monochrous Bleeker, Nat. Tijdschr. Ned. Ind. X p. 384.

Gymnothorax monochrous Bleeker, Atl. Ichth. IV p. 106.

A young specimen of circa $100 \mathrm{~mm}$ length, from coralreefs at Ambon, may possibly belong to the above named species.

5. Gymnothorax? spec. juv.

4. very small specimens from the reef at Saonek, 'Decemb. 1909.

Echidna Forster.

1. Echidna nebulosa (Abl.).

Muraenc nebulosa J. N. Ahl, De Mur. et Ophichth. p. 5.

Echidna variegata Bleeker, Atl. 1chth. IV p. 80.

Muraena nebulosa Günther, Fische der Südsee, Heft IX p. 423.

1 spec. $430 \mathrm{~mm}$, Saonek.

2. Echidna delicatula (Kp.).

Poecilophis delicatulus Kaup, Arch. Naturg. XXXII, I. p. $6 \%$.

Echidna delicatula Bleeker, Atl. Ichth. IV p. 78.

Muraena amblyodon Günther, Cat. Brit. Mus. VIII p. 132. pro parte.

Echidna delicatula Jordan \& Seale, Bull. Bur. Fish. XXV p. 204.

2 spec. 350 and $450 \mathrm{~mm}$, from Saonek, December 1909. 
3. Echidna spec. juv.

Two small specimens 65 and $67 \mathrm{~mm}$, from the reef at Saonek. Possibly they are young E. polyzona Rich.

\section{Anarchias Jordan \& Seale ${ }^{\mathbf{1}}$.}

1. Anarchias allardicei Jord. \& Seale ${ }^{1}$ ).

Anarchias allardicei Jordan \& Seale, Bull. Bur. Fish. XXV p. 204.

Anarchias knighti Jordan \& Seale, Bull. Bur. Fish. XXV p. 205.

Muraena allardicei Günther, Fische der Südsee, Heft IX p. 421.

2 specimens, $7 \%-138 \mathrm{~mm}$, from Ambon, agree in all respects with A. allardicei except the length of the snout, which is like that of $A$. knighti. These two species however have been, according to me rightly, united by Günther.

\section{Myctophidae.}

Saurida Cuvier \& Valenciennes.

1. Saurida tumbil (Bl.).

Salmo tumbil Bloch, Ausländ. Fische, IX p. 112.

Saurida tumbil Bleeker, Atl. Ichth. VI p. 155.

One specimen, $104 \mathrm{~mm}$, from the fishmarket at Ambon, Dec. \%. 1909.

Synodus Gronovius.

1. Synodus variegatus (Lac.).

Salmo variegatus Lacépède, Hist. Nat. Poissons, V p. $15 \%$

Synodus synodus Bleeker, Atl. Ichth. VI p. 154 (nec L.).

One specimen, $142 \mathrm{~mm}$, from the reef at Saonek, December 1909.

\section{Centriscidae.}

A eoliscus Jordan \& Starks.

1. Aeoliscus strigatus (Gthr.)

Amphisile strigata Günther, Cat. Brit. Mus. III p. 528.

Aeoliscus strigatus Max Weber, Siboga-Exp. Fische; p. 98.

18 specimens, $75-97 \mathrm{~mm}$, Beo, Majalibit-bay, Waigeu, January 1910.

3 specimens, 14-23 mm, Buton, Dr. Justesen leg.

Fistularidae.

Fistularia Linné.

1. Fistularia depressa Gthr.

Fistularia depressa Günther, Challenger Report, Shore Fishes, p. 69.

1 spec. $320 \mathrm{~mm}$, Ambon, fishmarket, December 7. 1909.

1 spec. $480 \mathrm{~mm}$, Saonek, January 10. 1910.

1) The genus, as well as the two species cited here are described by Jordan \& Seale under the heading: "Anarchias Jordan \& Starks, new genus." As there is no reference to any work of Jordan \& Starks, where descriptions of this genus and species occur, I think it correct to mention Jordan \& Seale and not Jordan \& Starks as the author's. 
Aulostomidae.

Aulostomus Lac.

1. Aulostomus valentini (Blkr.).

Polypterichthys valentini Bleeker, Nat. Tijdschr. Ned. Indië, IV p. 608.

Aulostoma chinense Günther, Cat. Brit. Mus. III p. 538 (nec L.).

2 specimens, 160 and $250 \mathrm{~mm}$, Ambon, February 1910.

Both specimens show lighter cross bars, running at regular intervals on the body. It is worth mentioning that these bars are continued on the elongated snout, which fact may be regarded as one evidence more against the lately advocated theory, that cross bars are correlated with the segmentation of the body.

\section{Syngnathidae.}

\section{Syngnathus Artedi.}

1. Syngnathus brevirostris Rüpp.

Syngnathus brevirostris Rüppell, Neue Wirbelthiere, Fische, p. 144. Syngnathus andersonii Bleeker, Nat. Tijdschr. Ned. Ind. XV p. 465.

Syngnathus tetrophthalmus Bleeker, Nat. Tijdschr. Ned. Ind. XV p. $46 \%$

Syngnathus brevirostris Günther, Cat. Brit. Mus. VIII p. $16 \%$.

Syngnathus tetrophthalmus Günther, Cat. Brit. Mus. VIII p. 169.

Syngnathus brevirostris Klunzinger, Synopsis Fische Roth. Meer. p. 562.

Syngnathus brevirostris Max Weber, Siboga-Exp. Fische, p. 106.

2 specimens, 24-26 mm, from the reef at Saonek, December 1909 and January 1910.

Both specimens show distinct filaments on the head as well as on the body. I find these too in much older specimens from the Malay Archipelago.

2. Syngnathus spicifer Rüpp.

Syngnathus spicifer Rüppell, Neue Wirbelthiere, Fische, p. 143.

Syngnathus spicifer Günther, Cat. Brit. Mus. VIII p. 172.

Syngnathus spicifer Klunzinger, Synopsis Fische Roth. Meeres, p. 650.

One specimen $91 \mathrm{~mm}$, from river Rabiai, Waigeu, December 31. 1909 (fresh water).

One specimen $63 \mathrm{~mm}$, from Kairatu, West-Ceram, February 1\%. 1910.

3. Syngnathus haematopterus Blkr.

Syngnathus haematopterus Bleeker, Verh. Bat. Gen. XXV p. 20.

Syngnathus haematopterus Günther, Fische d. Südsee, Heft IX p. 431.

8 spec., 50—5y mm, Saonek, reef. December 1909, January 1910.

$$
\text { Doryrhamphus. Kp. }
$$

1. Doryrhamphus brachyurus (Blkr.).

Syngnathus brachyurus Bleeker, Verh. Bat. Gen. XXV p. 16.

Doryichthys brachyurus Günther, Cat. Brit. Mus. VIII p. 184. Fische der Südsee, Heft IX p. 433.

2 specimens, 108 and $126 \mathrm{~mm}$, from a freshwater brook near Kajeli, Buru, December 9. 1909.

5 specimens, $74-183 \mathrm{~mm}$, from Kairatu, West-Ceram, February 16. (brackish).

2. Doryrhamphus mento (Blkr.).

Syngnathus mento Bleeker, Act. Soc. Indo-Neerl. I p. $\% 5$.

One specimen, $62 \mathrm{~mm}$ long, river at Kajeli, Buru, Dec. 9. 1909 (fresh water). 
3. Doryrhamphus caudatus (Pet.)

Microphis caudatus Peters, Monatsber. Akad. Wiss. Berlin, 1868, p. $2 \% 6$.

Doryichthys caudatus Günther, Fische der Südsee, Heft IX p. 432.

2 spec. 60-67 mm, river Waihå, Waigeu, December 20. 1909, fresh water.

2 spec. $140 \mathrm{~mm}$ long, upper course of the river Tuba, West Ceram, Febr. 27. 1910.

9 spec. 110-115 mm long, from a brook near Kairatu, W. Ceram, Febr. 20. 1910.

A small specimen, $44 \mathrm{~mm}$, from Kajeli, Buru (fresh water), probably belongs to this species too.

4. Doryrhamphus brevidorsalis $\mathrm{n}$. sp.

D. 24. P. 1\%. Cingulum $16+28$. Body higher than broad, its height almost 20 times in the total length. Head $6_{5}^{*}$ in total length, almost 3 in length of head and trunk. Tail slightly longer than trunk and head together. Upper profile of snout concave. Snout about equal to postorbital part of head and twice as long as eye, with a median ridge, ending before the eyes. Orbital ridges continued on the posturbital part of the head, but not continuous with the dorsal edges of the body. A median slightly scalloped ridge begins behind the eyes and is continued to the second body-ring. Operculum with a strong median ridge and radiating striae. Edges of the body very slightly serrated between the rings, those of the tail almost smooth. The dorsal edges of the body are not continuous with those of the tail and end on the $5^{\text {th }}$ caudal ring. The dorsal edges of the tail begin on the last body-ring. The lateral line bends downward and passes in the ventral edges of the tail. The median ventral ridge of the body is not very prominent. The dorsal fin begins on the last body-ring and ends on the beginning of the sixth tail-ring. Colour light brown. A dark band runs from the snout through the eye and the operculum and is continued on the body, where it becomes indistinct. A light ocellus with dark border on each caudal ring along its ventral margin.

One specimen, $42 \mathrm{~mm}$ long, from a stream near Kajeli, Buru, December 9. 1909 (fresh water).

This species seems to be allied to $D$. caudatus (Pet.), from which it differs in the shorter dorsal fin, which has a smaller number of rays.

\section{Coelonotus Peters.}

1. Coelonotus leiaspis (Bleeker).

Syngnathus leiaspsis Bleeker, Verh. Bat. Gen. XXV p. 20.

Hemithylacus leiaspis Kaup, Cath. Lophobr. Fish. Brit. Mus. p. 61.

Coelonotus leiaspis Günther, Cat. Brit. Mus. VIII p. 188.

Syngnathus leiaspis Duméril; Hist. Nat. Poiss. II p. 572.

Hemithylacus leiaspis Duméril, 1. c. p. 599.

Coelonotus leiaspis Jordan \& Richardson, Bull. Bur. Fisheries, XXVII p. 246.

One , $94 \mathrm{~mm}$ long, from a river at Kajeli, Buru, Dec. 9. 1909 (fresh water).

One $\sigma^{\gamma}, 159 \mathrm{~mm}$ long, from the river Rabiai, Waigeu, Dec. 31. 1909 (fresh water).

This species was described as Syngnathus leiaspis by Bleeker after two female specimens from Java. Kaup, who was able to examine males of this species, also from Java, founded the genus Hemithylacus for this species, on account of the abdominal egg-pouch and other characteristics. Günther united this genus with Peter's genus

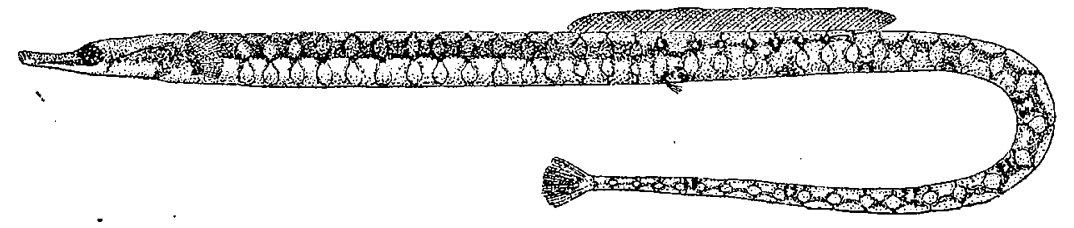

Fig. 3. Coelonotus leiaspis (Blkr.)

Coelonotus, based on a species of which males were unknown, but agreeing in its generic characters in every respect with Hemithylacus. 
Coelonotus leiaspis was hitherto only known from Java, the Philippines and Madagascar. By previous authors the coloration of this species is described as uniform, which is not in accordance with my well-preserved specimens, as may be seen in the accompanying figure. In the Waigeu-specimen the upper sides of the body and tail are brown, the under side yellowish. A dark brown stripe running from the hinder margin of the eye along the sides of the trunk. The anal ring, and the $2^{\text {nd }}, 4^{\text {th }}, 5^{\text {th }}, 7^{\text {th }}, 10^{\text {th }}, 13^{\text {th }}, 15^{\text {th }}, 18^{\text {th }}, 22^{\text {nd }}$ and $26^{\text {th }}$ tailring are speckled with brown on the ventral side, giving to the rings a tortoiseshell-like appearance. In the Buru-specimen the markings on the tail-rings are not visible, and the brown pigment of the sides of trunk and tail is concentrated along the margins of the rings and the intersutural plates. These last, being round and almost white, form a row of brownedged ocelli.

\section{Gasterotokeus Heckel.}

1. Gasterotokeus biaculeatus (B1.). Syngnathus biaculeatus Bloch, Ausl. Fische IV p. 10. Gasterotokeus biaculeatus Günther, Cat. Brit. Mus. VIII p. 194. Fische der Südsee, Heft IX p. 434.

4 spec., 160—200 mm, fishmarket at Ambon, December \%. 1909.

1. spec., $146 \mathrm{~mm}$, fishmarket at Macassar, March 11. 1910.

\section{Hippocampus Rafinesque.}

1. Hippocampus kuda Blkr.

Hippocampus kuda Bleeker, Nat. Tijdschr. Ned. Ind. III p. 82.

Hippocampus guttulatus Günther, Cat. Brit. Mus. VIII p. 202 (partim).

Hippocampus kuda Jordan \& Snyder, Proc. U. S. Nat. Mus. XXIV p. 15

Hippocampus guttulatus Günther, Fische der Südsee, Heft IX p. 435 (S. Syn.).

One specimen, $165 \mathrm{~mm}$, from Ambon, February 1910.

\section{Scomberesocidae.}

Hemirhamphus Cuv.

1. Hemirhamphus far (Forsk.).

Esox far Forskal, Descript. Anim. p. 6\%.

Hemirhamphus far Bleeker, Atl. Ichth. VI p. 54.

Hemirhamphus far Günther, Fische d. Südsee II p. $35 \%$.

One specimen, $240 \mathrm{~mm}$, obtained at the fishmarket of Ambon. Dec. \%, 1909.

2. Hemirhamphus quoyi C. V.

Hemirhamphus quoyi Cuvier \& Valenciennes, Hist. Nat. Poiss. XIX p. 35.

Hemirhamphus quoyi Bleeker, Atl. Ichth. VI p. $5 \%$

10 specimens, $154-203 \mathrm{~mm}$. Beo, Majalibit-bay, Waigeu. January 1910.

3. Hemirhamphus (Zenarchopterus) buffonis C. V.

Hemirhamphus Buffonis Cuvier \& Valenciennes, Hist. Nat. Poiss. XIX p. 48.

Zenarchopterus Buffoni Bleeker, Atl. Ichth. VI p. 62.

One specimen, $83 \mathrm{~mm}$ (beak damaged), Saonek, Dec. 19. 1909.

One specimen, $126 \mathrm{~mm}$ long, Bajon, Majalibit-bay, Waigeu (salt water).

4. Hemirhamphus (Zenarchopterus) dispar C. V.

Hemirhamphus dispar Cuvier \& Valenciennes, Hist. Nat. Poiss. XIX p. 58.

Zenarchopterus dispar Bleeker, Atl. Ichth. VI p. 63.

Zenarchopterus dispar Günther, Fische der Südsee, II p. 358. 
One $\sigma^{7}, 140 \mathrm{~mm}$ long, Saonek, December 19. 1909.

$3 \sigma^{\top} \sigma^{\top}, 150-1 \% 0 \mathrm{~mm}$, Mirdika-river, Ambon, February 14. 1910.

\section{Atherinidae.}

\section{A therina Artedi.}

1. Atherina forskåli Rüpp. Atherina Forskåli Rüppell, Neue Wirbelth. p. 132. Atherina lacunosa Bleeker, Nat. Tijdschr. Ned. Indie, V p. 504. Atherina Forskåli Günther, Cat. Brit. Mus. III p. $39 \%$. Atherina Forskali Day, Fishes of India, $4^{\circ}$ p. 345. Atherina lacunosa Günther, Fische der Südsee, p. 213 (p. p.). Atherina Forskäli Klunzinger, Fische des Roten Meeres, p. 130.

3 spec. 82-86 mm, Ambon, fishmarket, December \%, 1909.

My specimens agree with the descriptions of $A$. forskäli. The silvery band along the sides however, is, as mentioned under $A$. pinguis, slightly narrower than it ought to be, not quite reaching the middle of the fourth row of scales.

2. Atherina pinguis Lac. Atherina pinguis Lacépède, Hist. Nat. Poissons, V p. 372. Atherina pectoralis Cuvier \& Valenciennes, Hist. Nat. Poissons, X p. $44 \%$. Atherina pinguis Bleeker, Act. Soc. Sc. Ind. Neerl. VIII p. 85. Atherina pinguis Günther, Cat. Brit. Mus. III p. 339. Atherina lacunosa Günther, Fische der Südsee, II p. 213 (partim). Atherina pinguis Day, Fishes of India; $4^{\circ}$ p. 344. Atherina pinguis Klunzinger, Fische d. Roten Meeres, p. 130. Atherina pinguis Sauvage, Hist. de Madagascar, Poissons, p. 409. Atherina pinguis Max Weber, Siboga-Exp. Fische, p. 135.

1 spec. $83 \mathrm{~mm}$, from Saonek. December 1909:

- I am not quite sure that my specimen really belongs to the above-named species, the most important discrepance being the broad silvery band along the sides, which covers the upper half of the fourth lateral row of scales, is in fact, broader than the band in my specimens which I refer: to $A$. forskali. In other respects it agrees with the descriptions of A. pinguis, notably in the presence of a dusky blotch at the end of the pectoral.

Note. Ogilby's recent investigations on these species (Mem. Queensl. Mus. I. 1912, p. 36) came too late in my hands to use them in the determination of my specimens.

3. Atherina temminckii Blkr.

Atherina Temminckii Bleeker, Nat. Tijdschr. Ned. Ind. V. p. 506.

One specimen, $76 \mathrm{~mm}$, from Kairatu, W. Ceram, Febr. 28, 1910.

My specimen shows two longitudinal rows of black spots under the lateral line, as in $A$. endrachtensis and in some of my specimens of $A$. duodecimalis. In all other respects it agrees with Bleeker's description.

4. Atherina duodecimalis C.V.

Atherina duodecimalis Cuvier \& Valenciennes, Hist. Nat. Poissons, X p. 458.

Atherina duodecimalis Bleeker, Nat. Tijdschr. Ned. Ind. II p. 485.

Atherina duodecimalis Sauvage, Hist. Madagascar. Poissons, p. 406.

3 spec. 6\%-105 mm, Majalibit-bay, Waigeu, Jan. 1910.

The two longitudinal rows of scales beneath the silvery band have more or less distinct 
black dots, a feature not in accordance with the descriptions of the above-named authors, and giving to my specimens the appearance of $A$. endrachtensis. Last-named species, as shown by my specimen from the same locality and of the same length as the two smaller $A$. duodecimalis from my collection, differs by its longer pectoral, which is almost as long as the head, as well as by the much wider interorbital space, which is greater than the diameter of the eye, whereas it is less than the eye in A. duodecimalis. Another difference between these two species, mentioned by Sauvage 1.c., is, that in A. duodecimalis the first dorsal is at an equal- distance from the base of the caudal and from the hindmargin of the eye, while in $A$. endrachtensis it is nearer to the caudal.

\section{Atherina endrachtensis Q.G.}

Atherina endrachtensis Quoy \& Gaimard, Voyage Uranie et Physicienne, Zoologie, p. 334. Atherina endrachtensis Cuvier \& Valenciennes, Hist. Nat. Poissons, X p. 456.

Atherina bimanensis Bleeker, Journ. Ind. Archipel, II p. 638.

Atherina endrachtensis Sauvage, Hist. Madagascar. Poissons, p. 406.

Atherina endrachtensis Max Weber, Siboga-Exp. Fische, p. 136.

1 spec. $63 \mathrm{~mm}$, Majalibit-bay, Waigeu, Jan. 1910.

1 spec. $113 \mathrm{~mm}$, from Kairatu, West Ceram, February 28. 1910.

I have but little doubt that the species shortly described by Bleeker as A. bimanensis, belongs to $A$. endrachtensis.

I have made some remarks on this species under $A$. duodecimalis.

5. Atherina spec. juv.

One specimen, $24 \mathrm{~mm}$, from Kairatu, W. Ceram, February 16. 1910.

\section{Melanotaeniidae.}

Rhombatractus Gill.

1. Rhombatractus catherinae de Bfrt. (Plate II, fig, 1).

Rhombatractus catherinae de Beaufort, Zool. Anz. XXXVI p. 250.

D. I. 4 (rarely 3 or 5). I. 11-13 (generally 12). A. I. $19-23$ (generally 20).

P. 13-14. V. I. 5. L. 1. 32--35 (generally 34). L. t. 12 (11 $\left.\frac{1}{2}\right)$.

Strongly compressed. Dorsal profile almost straight from first dorsal to point of snout, sloping more rapidly in large than in small specimens; horizontal from first to second dorsal and sloping down from here to the tail. Ventral profile very convex. Height in specimens of $100 \mathrm{~mm}$ and longer $2 \frac{3}{4}-3$, in smaller specimens $3-3 \frac{3}{4}$ times in the total length, and $2 \frac{1}{5}-2 \frac{1}{2}$ and $2 \frac{1}{3}-3 \frac{1}{4}$ times in the length without caudal. Length of head $4-4 \frac{1}{2}$ times in the total, $3 \frac{1}{5}-3 \frac{3}{4}$ in the length without caudal. Head moderately pointed. Diameter of eye $3-3 \frac{4}{5}$ times in the length of the head and $1 \frac{1}{2}$ times in the flat or even slightly convex interorbital space. Snout rather short, $2 \frac{2}{3}$ to almost 3 times in length of head. Gape of mouth oblique, more horizontal in the first $\frac{1}{3}$ of its length. Upper jaw covered by praeorbital when the mouth is closed. The intermaxillary does not reach below the frontmargin of the eye. It is swollen and covered on its whole surface with several rows of conical small teeth. The mandibles are also swollen in front and have similar teeth, which decrease in number posteriorly. A narrow band of teeth on the vomer. No teeth on the palatines. Teeth on the pterygoids present. Tongue edentulous. Scales cycloid, partly with feeble indentations; dorsally they reach to the eyes; on the cheeks in 3 longitudinal rows, reaching under the eyes. Pectorals longer than head without snout. Base of ventrals below that of pectorals in large specimens, in smaller specimens more backward. The ventrals reach to the second or third anal ray. The first spine of the first dorsal is about opposite to that of the anal and equal 
to that of the second dorsal, both being about $\frac{1}{3}$ of the length of the head. In small specimens it is comparatively longer. There are about 16 rows of scales between the vertex and first dorsal spine. The anal spine is curved backward and is equal to the diameter of the eye. Dorsal and anal fin of about the same height. Caudal incised, less so and with the lobes more rounded in large specimens. Peduncle of tail scarcely longer than high in large specimens.

Colour in spirits brown or yellowish brown on the back, ventrally whitish. A broad black lateral band runs from the hinder border of the eye over the base of the pectoral to the caudal, at least as broad as one scale. For colours in fresh state see fig. 1, on Plate II.

All specimens were captured in fresh water, in most cases in the uppercourse of the rivers and brooks, where the ground is rocky and the water clear. They live in shoals.

15 spec. 59-119 mm, river Rabiai, Waigeu. Dec. 31. 1909.

10 spec. $18-90 \mathrm{~mm}$, brook Wai Semi, Waigeu. Jan. 1910.

226 spec. $12-89 \mathrm{~mm}$, brook Wai Menil, Waigeu. Jan. 1910.

1 spec. $96 \mathrm{~mm}, \ldots$ river Bajon, Waigeu. Jan. 1910.

I have named this species after my wife, who accompanied me on my travels and had a great share in the collecting of zoological specimens.

\section{Mugilidae.}

Mugil L.

1. Mugil rossi Blkr.

Mugil rossi Bleeker, Nat. Tijdschr. Ned. Ind. VII p. 45. id. XVI p. $2 \% 6$.

Mugil rossi Max Weber, Siboga-Exp. Fische, p. 138.

1 spec. $69 \mathrm{~mm}$, Saonek, January 1910.

1 spec. $92 \mathrm{~mm}$, Sorong, New Guinea, January 1910, L. de Bruyne leg.

2 spec. 51-61 mm, Ambon, Batu merah, March 1910.

I range my specimens under $M$. rossi on account of the position of the dorsal, the origin of which is situated nearer to the base of the caudal than to the tip of the snout.

$I$ am somewhat in doubt about the validity of this species, which may be a variety of M. waigiensis, as has been suggested by Günther.

2. Mugil sundanensis Blkr.

Mugil sundanensis Bleeker, Nat. Tijdschr. Ned. Indië, IV p. 265.

Mugil brachysoma Bleeker, Nat. Tijdschr. Ned. Indië, IX p. 399.

Mugit sundanensis Bleeker, Nat. Tijdschr. Ned. Indië, XVI p. 2\%6. Ac. Soc. Sc. IndoNeerl. VIII p. 45.

One specimen, $235 \mathrm{~mm}$, from mouth of river at Buton, isle of Buton, Dec. 3; 1909

(brackish). $\therefore \ldots$, .

3. Mugil subviridis $\mathrm{C}$. V.

Mugil subviridis Cuvier \& Valenciennes, Hist. Nat. Poiss. XI p. 115.

Mugil subviridis Day, Fishes of India, $4^{\circ}$ p. 353.

One specimen, $215 \mathrm{~mm}$, Kajeli, Buru, Dec.' 9, 1909 (fresh water).

4. Mugil bleekeri Gthr?

Mugil bleekeri Günther, Cat. Brit. Mus. III p. 445.

Mugil borbonicus Bleeker, Nat. Tijdschr. Ned. Ind̦ië, XVI p. 2\%9; idem XVIII p. 375.

7 spec. 5\%-110 mm, Saonek, December 1909 and January 1910.

1 spec. $98 \mathrm{~mm}$, Buli, Halmahera, collected by Mission. Maan.

if spec. 69-80 mm, Batu Merah, Ambon, March 1910.

The following East-Indian Mugil-species: M. seheli Forsk. (= axillaris Blkr.), bleekeri 
Gthr., suppositus Gthr. (= borbonicus Cant.) and caeruleomaculatus (Lac.) Blkr. have the following points in common: The membrana palpebralis does not attain or scarcely attains the iris. The maxillary is entirely or almost hidden by the praeorbital. There is an elongated pointed scale in the axil and a black spot at the upperside of the base of the pectoral. The second dorsal and anal fin are opposite to eachother. The number of scales in the lateral line is not far from 40 , being $40-45$ in $M$. seheli and $38,38-39$, and 40 in the three other species.

The chief differences between these species are recorded in the following table:

\begin{tabular}{|c|c|c|c|c|}
\hline & M. seheli & M. suppositus & M. bleekeri & M. coeruleomaculatus \\
\hline $\begin{array}{l}\text { Upperlip } \\
\text { Position of first } \mathrm{D} . \\
\text { Anal } \\
\text { Pectoral } \\
\text { Lin. lat. }\end{array}$ & $\begin{array}{c}\text { thick (thin?) } \\
\text { as far from snout } \\
\text { as from base of caudal } \\
\text { III } 9-10 \\
\text { shorter than head } \\
40-45\end{array}$ & $\begin{array}{c}\text { thin } \\
\text { as far from snout } \\
\text { as from base of caudal } \\
\text { III } 8 \\
\text { shorter than head } \\
40\end{array}$ & $\begin{array}{l}\text { thin } \\
\text { nearer to base of } \\
\text { tail than to snout } \\
\text { III } 9-10 \\
\text { shorter than head } \\
38-39\end{array}$ & $\begin{array}{c}\text { thick } \\
\text { as far from snout } \\
\text { as from base of caudal } \\
\text { III } 9-10 \\
\text { longer than head } \\
38\end{array}$ \\
\hline
\end{tabular}

According to this table $M$. caeruleomaculatus may be easily distinguished by its loug pectoral. The differences between the remaining three are not so salient. $M$. suppositus is chiefly characterised by its small number of soft anal rays. Although the number of these rays is fairly constant in Mugil, I think Günther went too far in creating a new species, known moreover from a single specimen only, upon this characteristic, while it agrees in all other points with $M$. seheli. Last named species differs from $M$. bleekeri only in having 1-6 scales more in the lateral line and in the fact that the first dorsal is as far from the snout as from the base of the caudal. Considering the great number of common points I don't think that the two named differences are sufficient to separate them, and I think it very probable that, when more material will be available, $M$. seheli, $M$. suppositus and $M$. bleekeri may be united. For the moment, having no material at my disposal, I will keep them apart.

My specimens agree in all respects with $M$. bleekeri; but for the lips, which are thick and even slightly papillated in the specimens caught at Saonek in December. Max Weber (Siboga-Exp. Fische p. 139) has mentioned thick lips in his specimens of M. bleekeri. I cannot lay much stress on this fact, as $\mathrm{f}$. $\mathrm{i}$. Bleeker states of $M$. axillaris ( $=M$. seheli) that the lips are thick, while Günther (Südseefische) calls them thin, as is also done by Klunzinger (Fische des Rothen Meeres).

Jordan and Seale (Bull. Bur. Fish. XXV p. 21\%) unite M. axillaris and caeruleomaculatus, I think wrongly, as the pectoral is stated to be longer than the head in last-named species by Cuvier \& Valenciennes, Bleeker and Günther.

5. Mugil ceramensis Blkr.

Mugil ceramensis Bleeker, Nat. Tijdschr. Ned. Indië, III p. 699. id. XVI p. 2\%\%. Act. Soc. Sc. Indo-Neerl., VIII p. 48.

5 specimens, 17\%-247 mm, Kajeli, Buru, Dec. 9. 1909 (fresh water).

6. Mugil borneensis Blkr.

Mugil borneensis Bleeker, Nat. Tijd. Ned. Indië, II p. 201, id. XVI p. 2\%8.

One specimen, $235 \mathrm{~mm}$, Kajeli, Buru, Dec. 9. 1909 (fresh water).

\%. Mugil crenilabis Forsk.

Mugil crenilabis Forskål, Descr. Aminal. p. 73.

? Mugil macrocheilos Bleeker, Nat. Tijdschr. Ned. Indië, VII p. 43.

Mugil crenilabis Günther, Fische der Südsee, p. 219.

Mugil crenilabis Klunzinger, Fische Roth. Meer. 40. p. 131, 132.

1 spec. $100 \mathrm{~mm}$ long, from Saonek, December 1909. 
As part of the scales had fallen off, I could not ascertain the exact number of them in the 1.1., but in other respects the fish so closely agrees with the descriptions of Günther and Klunzinger, that 1 have no doubt about the correctness of my determination. I am not sure that Günther is right in uniting $M$. macrocheilos Blkr. with crenilabis, as Bleeker states that the head is smaller, the fringe on the upper jaw uniserial etc.

\section{Mugil spec. juv. (borneensis Blkr.?)}

3 young specimens, $37-43 \mathrm{~mm}$, from Kairatu, W. Ceram, possibly belong to Mugil borneensis Blkr. I find however some differences in the length of the head and in the place of the anal fin, which may be due to their juvenile age.

A specimen of $35 \mathrm{~mm}$ from the reef at Saonek, December 1909, probably also belongs to this species.

9. Mugil? spec. juv.

A larva of $11 \mathrm{~mm}$ from the reef at Saonek, January 1910, possibly belongs to this genus.

\section{Polynemidae.}

\section{Polynemus L.}

1. Polynemus zophomus Jordan \& Me Greg.

Polynemus zophomus Jordan \& Mc Gregor, Proc. U. S. Nat. Mus. XXX p. 814.

Polydactylus zophomus Jordan \& Seale, Bull. Bur. Fish. XXVI p. 11.

Polynemus zophomus Max Weber, Siboga-Exp. Fische, p. 142.

One specimen, $195 \mathrm{~mm}$, from the fishmarket at Ambon, Dec. \%. 1909.

\section{Sphyraenidae.}

Sphyraena Artedi.

1. Sphyraena commersonii C.V.

Sphyraena commersonii Cuvier \& Valenciennes, Hist. Nat. Poiss. III p. 352.

Sphyraena commersonii Bleeker, Verh. Bat. Gen. XXVI p. 15.

Sphyraena commersonii Günther, Cat. Brit. Mus. II p. 338.

Sphyraena commersonii Day, Fishes of India, 4". p. 343.

One specimen, $110 \mathrm{~mm}$ long, from Saonek, December 18. 1909.

One specimen, $87 \mathrm{~mm}$, from Buton (Dr. Justesen leg.).

I am not quite sure of the determination of last-named specimen, as the maxillary does by far not reach below the front border of the eye; this may however be due to the youth of the specimen.

A Sphyraena of $44 \mathrm{~mm}$, from the reef at Saonek, may possibly belong to this species, but it has the markings of Sphyraenc jello C.V. However, I can't count more than about $80-90$ scales in the 1.1 .

\section{Opbiocephalidae.}

$$
\text { Ophiocephalus Bloch. }
$$

1. Ophiocephalus striatus $\mathrm{Bl}$.

Ophiocephalus striatus Bloch, Ausländ. Fische VIII p. 141.

Ophiocephalus striatus Bleeker, Verh. Akad. Amsterdam XIX p. 42.

Many young specimeris, $15-47 \mathrm{~mm}$, from Telaga Tihu, Ambon, March 1910. 


\section{Holocentridae.}

\section{Holocentrum Artedi.}

1. Holocentrum tiereoides Blkr.

Holocentrum tiereoides Bleeker, Nat. Tijdschr. Ned. Ind. V p: 334. Ned. Tịjdschr. Dierk. IV p. 228.

3 specimens, 136-152 mm, Ambon, March 1910.

2. Hoiocentrum rubrum (Forsk.).

Sciaena rubra Forskä, Descript. Animal. p. 48.

Holocentrum rubrum Bleeker, Ned. Tijdschr. Dierk. IV p. 224

1 spec. $102 \mathrm{~mm}$, Saonek.

1 spec. $143 \mathrm{~mm}$, Ambon, February 1910.

3. Holocentrum sammara (Forsk.).

Sciaena sammara Forskål, Descript. Animal. p. 48.

Holocentrum sammara Bleeker, Ned. Tijdschr. Dierk. IV p. 213.

One specimen, $109 \mathrm{~mm}$, from Saonek.

$$
\text { Myripristis Cuv. }
$$

1. Myripristis adustus Blkr.

Myripristis adustus Bleeker, Nat. Tijdschr. Ned. Indië $1 \nabla$ p. 108. Ned. Tijdschr. Dierk. IV p. 193.

1 specimen from Buton, December 3. 1909.

It is with some hesitation that I range my specimen under this name, as it lacks the black markings characteristic of this species. It has however the axil and the hindborder of the operculum black. There are no teeth on the chin, as stated to be the case in M. $m a$ crolepis, with which species $M$. adustus is closely related (cf. Max Weber, Siboga-Exp. Fische p. $18 \%$ ).

\section{Centrarchidae.}

\section{Kuhlia Gill.}

1. Kuhlia marginata (C. V.).

Dules marginatus Cuvier \& Valenciennes, Hist. Nat. Poiss. III p. 116.

Moronopsis ciliatus Bleeker, Atl. Ichth. VII p. 120.

Kuhlia marginata Boulenger, Cat. Brit. Mus. sec. ed. vol. I p. 38.

1 spec. $190 \mathrm{~mm}$, Kajeli, Buru, Dec. 9. 1909. (fresh water).

2 spec. 150 and $1 \% 0 \mathrm{~mm}$, stream at Batjan, Dec. 11. 1909.

1 spec. 108 mm, Buli, Halmahera (Mission. Maan leg.).

1 spec. $82 \mathrm{~mm}$, river Lam-lan, Fofak Bay, North Waigeu, January 5. 1910.

8 spec. $83-210 \mathrm{~mm}$, river Ėme, W. Ceram, February 20 and 24. 1910.

2 spec. $\% 0-\% 9 \mathrm{~mm}$, upper course of river Tuba, West Ceram, February 2\%. 1910.

2. Kuhlia rupestris (Lac.).

Centropomus rupestris Lacépède, Hist. Nat. Poiss. IV p. 252 and 273.

Moronopsis rupestris Bleeker, Atl. Ichth. VII p. 121.

Kuhlia rupestris Boulenger, Cat. Brit. Mus. $2^{\text {nd }}$ ed. vol. I p. 36.

2 spec. 270 and $290 \mathrm{~mm}$, from a river near Kajeli, Buru, December 9. 1909 (fresh water). 
Kyphosidae.

1. Kyphosus cinerascens (Forsk.).

Kyphosus Lac.

Sciaena cinerascens Forskål, Descript. Anim. p. 53.

Pimelepterus tahmel Günther, Cat. Brit. Mus. I p. 499.

Pimelepterus cinerascens Bleeker, Atl. Ichth. IX p. 15.

Kyphosus cinerascens Jordan \& Thomson, Proc. U. S. Nat. Mus. XLI p. 596.

One specimen, $390 \mathrm{~mm}$, from Sanana, Sula islands, Dec. 10. 1909.

\section{Toxotidae.}

1. Toxotes jaculator Pall.

Toxotes Cuvier.

Toxotes jaculator Pallas, Phil. Transact. LVI p. 186.

Toxotes jaculator Bleeker, Atl. Ichth. IX p. 4.

3 specimens, 193-137 mm, Majalibit-bay, Waigeu.

Serranidae.

1. Centrogenys waigiensis (Q. G.).

Centrogenys Richardson.

Scorpaena waigiensis Quoy \& Gaimard. Zool. Voy. Uranie et Physicienne, p. 324.

Centrogenys waigiensis Bleeker, Atl. Ichth. VII p. 68.

A specimen of $93 \mathrm{~mm}$, from the fishmarket at Macassar, March 11. 1911.

Epinephelus Bloch.

1. Epinephelus pachycentrum (C.V.).

Serranus pachycentron Cuvier \& Valenciennes, Hist. Nat. Poiss. II p. 295.

Epinephelus pachycentrum Boulenger, Cat. Brit. Mus. 2nd ed. I p. 178.

One specimen, $4 \% \mathrm{~mm}$, from the reef at Saonek, December 1909.

One specimen, $56 \mathrm{~mm}$, from Ambon, February 1910.

2. Epinephelus fasciatus (Forsk.).

Perca fasciata Forskål, Descr. Animal. p. 40.

Epinephelus fasciatus Bleeker, Atl. Ichth. VII p. 66.

Epinephelus fasciatus Boulenger, Cat. Brit. Mus. $2^{\text {nd }}$ ed. I p. 238.

One specimen, $175 \mathrm{~mm}$, from the fishmarket at Ambon, March 1910.

3. Epinephelus summana (Forsk.).

Perca summana Forskal, Descript. Animal, p. 42.

Epinephelus summana Boulenger, Cat. Brit. Mus. $2^{\text {nd }}$ ed. I p. 248.

6 spec. $25-155 \mathrm{~mm}$, from the reef at Saonek.

Paracanthistius Bleeker.

1. Paracanthistius maculatus (B1.).

Bodianus maculatus Bloch, Ausländ. Fische, IV p. 48.

Paracanthistius leopardinus Bleeker, Atl. Ichth. VII p. 25.

Paracanthistius maculatus Bleeker, Atl. Ichth. VII p. 26.

Plectropoma maculatum Boulenger, Cat. Brit. Mus. 2 $2^{\text {nd }}$ ed. Vol. I p. 160.

2 specimens, 220 and $260 \mathrm{~mm}$, belonging to the variety maculatus, from the fishmarket at Macassar, March 12. 1910. 
1. Anyperodon leucogrammicus (C.V.).

Serranus leucogrammicus Cuvier \& Valenciennes, Hist. Nat. Poiss. II p. 259.

Anyperodon leucogrammicus Bleeker, Atl. Ichth. VII p. 28.

Anhyperodon leucogrammicus Boulenger, Cat. Brit. Mus. $2^{\text {nd }}$ ed. I p. $2 \% 0$.

One specimen, $280 \mathrm{~mm}$, from the fishmarket at Ambon, Febr. 12. 1910.

\section{Plesiops Cuvier.}

1. Plesiops nigricans (Rüpp.).

Pharopteryx nigricans Rüppell, Atlas Reise Afrika, p. 15.

Plesiops nigricans Rüppell, Neue Wirbelth. p. 5.

Plesiops coeruleolineatus Rüppell, Neue Wirbelth. p. 5.

Plesiops corallicola Bleeker, Nat. Tijdschr. Ned. Ind. IV p. 280.

Pharopteryx nigricans Jordan \& Seale, Bull. Bureau Fish. XXV p. 260.

Plesiops nigricans Max Weber, Siboga-Exp. Fische, p. 212.

9 spec. 14-138 mm, reef at Saonek, Dec. 1909, Jan. 1910.

2. Plesiops melas Blkr.

Plesiops melas Bleeker, Verh. Bat. Gen. XXII p. 9.

Pharopteryx melas Jordan \& Seale, Bull. Bur. Fish. XXV p. 261.

Plesiops melas Max Weber, Siboga-Exp. Fische, p. 213.

4 spec. 52-6\% $\mathrm{mm}$, from the reef at Saonek.

3. Plesiops? spec. juv.

I refer a small fish of $19 \mathrm{~mm}$ length with some doubt to this genus, as the membrane between the dorsal spines is only slightly incised.

$$
\text { Grammistes Artedi. }
$$

1. Grammistes sexlineatus (Thunb.).

Perca sexlineata Thunberg, Vetensk. Ac. Handl. Stockh. XIII p. 142.

Grammistes orientalis Bleeker, Atl. Ichth. VII p. $\% 0$.

Grammistes sexlineatus Boulenger, Cat. Brit. Mus. 2nd ed. I p. 346.

One specimen, $39 \mathrm{~mm}$, from the reef at Saonek, December 2\%. 1909.

$$
\text { Priacanthus Cuvier. }
$$

1. Priacanthus hamrur (Forsk.)

Sciaena hamrur Forskål, Descr. Animal, p. 45.

Priacanthus hamrur Bleeker, Atl. Ichth. VII p. 13.

Priacanthus hamrur Boulenger, Cat. Brit. Mus. $2^{\text {nd }}$ ed. I p. 355.

Three specimens, $200-210 \mathrm{~mm}$, Ambon, February 1910.

$$
\text { Ambassis C.V. }
$$

1. Ambassis urotaenia Blkr.

Ambassis urotaenia Bleeker, Nat. Tijdschr. Ned. Ind. III p. 25\%. Atl. Ichth. VIII p. 135.

Ambassis urotaenia Day, Fishes of India 4". p. 55.

Priopis lungi Jordan \& Seale, Bull. Bur. Fish. XXVI p. 18.

Ambassis urotaenia Evermann \& Seale, Bull. Bur. Fish. XXVI p. 75.

Ambassis lungi Evermann \& Seale, Bull. Bur. Fish. XXVI p. 75. 
l spec. $72 \mathrm{~mm}$, mouth of the river Rabiai, Waigeu, Dec. 31. 1909 (brackish).

6 spec. $80-96 \mathrm{~mm}$, from Ambon, partly from the river Batu merah, February and March 1910. 2 spec. 70 and $88 \mathrm{~mm}$, from the mouth of the river Riuapa, W. Ceram, February 16. 1910.

My specimens agree better with the description of Day than with that of Bleeker, having only one row of scales on the cheeks. In a specimen of Bleeker's collection too I find only one row, in stead of 2 as mentioned by Bleeker. I am of opinion that this difference is not sufficient to separate the forms with one row as $A$. lungi, as has been done by Jordan and Seale, as I am not aware that there is another noteworthy difference. It is true that these authors as well as Seale and Evermann also mention a broken lateral line as a characteristic of $A$. lungi. This does not hold good however, as on one of my specimens from Ambon and on another from Ceram the lateral line is continuous on one side, whereas it is interrupted at the other side.

2. Ambássis buruensis Blkr.

Ambassis buruensis, Bleeker, Nat. Tijdschr. Ned. Ind. XI p. 396.

Ambassis buruensis, Bleeker, Nat. Verh. Holl. Mpij d. Wetensch. 3 ${ }^{\text {de }}$ Verz., Deel II, $\mathrm{n}^{\circ} 2$, p. 98. Atl. Ichth. VIII p. $13 \%$.

Priopis buruensis, Jordan \& Seale, Bull. Bureau Fisheries XXVI, 1906, p. 18.

Ambon, river Mirdika 19 spec. 75-63 mm, Febr. 14. 1910.

Ambon, river Batu Merah 6 spec. $78-66 \mathrm{~mm}$. Febr. March, 1910.

Ambon, sea 1 spec. $75 \mathrm{~mm}$.

Buru, Kajeli, 1 spec. 62 mm, Dec. 9. 1909.

My specimens agree with Bleeker's description, but the orbital is serrated below, slightly in some specimens, very conspicuously in others. As I can not find other differences and as the serrations are almost obsolete in some individuals, I do not hesitate to bring my specimens to the above-named species.

29 young specimens $25-44 \mathrm{~mm}$, from the river Mirdika, Ambon, probably belong to this species too.

3. Ambassis commersoni C. V.

Ambassis commersonii Cuvier \& Valenciennes, Hist. Nat. Poiss. II p. $1 \% 6$.

Ambassis commersonii Bleeker, Atl. Ichth. VIII p. 136.

Ambassis commersonii Day, Fishes of India, $4^{\circ}$ p. 52.

One specimen, $1 \% 0 \mathrm{~mm}$, Kajeli, Buru, Dec. 9. 1909 (fresh water).

In every respect my specimen agrees with the description given by Bleeker, but for the number of scales in a row between the vertex and the first dorsal, which is about 16 or $1 \%$ in my specimen, and not about 13 as Bleeker states. By this higher number of scales my specimen agrees with Ambassis batjanensis Blkr., which species is said to have only 2 scales above the lateral line but otherwise seems to be very closely allied to $A$. commersoni, as has already been remarked by Day l.c.

4. Ambassis dussumieri C. V.

Ambassis dussumieri Cuvier \& Valenciennes, 1828. II p. 181.

Priopis argyrozona (K. \& v. H.), Cuvier \& Valenciennes, 1830. VI p. $3 \% 8$.

Chanda dussumieri Cantor, 1850. Cat. Mal. Fishes, p. 988.

Ambassis gymnocephalus Bleeker (nec Lacép.), Natuurk. Verh. Holl. Mpij d. Wetensch. $3^{\text {de }}$ Verz. II. $\mathrm{n}^{\circ} 2$ p. 99. Atl. Ichth. VIII p. 138.

Ambassis gymnocephalus Day (nec Lacép.) Fishes of India, $4^{\circ}$ p. 54.

Njanjef Waigeu, 25 Dec. 1910. 1 spec. $55 \mathrm{~mm}$.

Majalibit-bay, Waigeu, Jan. 1910. 9 spec. 55-45 mm.

Bleeker considered Lutjanus gymnocephalus of Lacépède to be the above-named species 
saying l. c.: "On reconnaît aisément l'espèce dans la figure du Lutjan gymocéphale de Lacépède". Day followed Bleeker's consideration in his "Fishes of India". However, when we consult the figure given by Lacépède (III pl. 23, fig. 3), we see a fish with an unbroken lateral line and with a much longer dorsal fin than that of. A. dussumieri. Moreover, Lacépède states in the text (IV p. 181): "Huit rayons aiguillonés et treize rayons articulés à la nageoire du dos". It is clear that this fish never can be A. dussurnieri. Cuvier \& Valenciennes II p. 131, suppose Lacépède's fish to be identical with $A$. commersonii, because Lacépède founded his species on a drawing made by Commerson; the discoverer of $A$. commersonii. They suppose that a mistake in the number of rays of the dorsal fin was made in the drawing. Günther, (Cat. Fishes I p. 223) also placed Lutjanus gymnocephalus among the sinonyms of A. commersonii, without acknowledging however its priority. I think it best to put Lutjanus gymnocephalus in the list of doubtful species of Ambassis. In this list Günther also places Priopis argyrozona (K. \& v. H.) C. V, a fish described by Cuvier and Valenciennes after a drawing of Kuhl and van Hasselt, who named the species. Bleeker, who later on got possession of this drawing, states that it represents his $A$. gymnocephalus.

\section{A pog on Lacépède.}

1. Apogon orbicularis C. V.

Apogon orbicularis Cuvier \& Valenciennes, Hist. Nat. Poiss. II p. 155.

Amia orbicularis Bleeker, Atl. Ichth. VII p. 79.

2 spec. $8 \%$ and $100 \mathrm{~mm}$, from the Majalibit-bay, Waigeu, Jan. 1910.

1 spec. probably from Ambon, $\% 0 \mathrm{~mm}$.

2. Apogon novemfasciatus C. $\mathrm{V}$. Apogon novemfasciatus Cuvier \& Valenciennes, Hist. Nat. Poiss. II p. 154. Apogon novemtasciatus Max Weber, Siboga Exp. Fische p. 224.

11 spec. $44-\% 0 \mathrm{~mm}$, from the reef at Saonek, Dec. 2\%. 1909.

3. Apogon ceramensis Blkr.

Apogon ceramensis Bleeker, Nat. Tijdschr. Ned. Indië, III p. 258.

Apogon ceramensis Bleeker, Atl. Ichth. VII p. 91.

5 spec. 80-90 mm, mouth of Batu mera, Ambon, Dec. 8. 1909.

5 spec. $11-80 \mathrm{~mm}$, Majalibit-bay, Waigeu, January 1911.

4. Apogon aureus (Lacép.).

Centropomus aureus Lacépède, Hist. Nat. Poiss. IV p. 253, 273.

Apogon aureus Bleeker, Atl. Ichth. VII p. 92.

12 spec. 14-85 mm, Saonek, December 1909.

5. Apogon sangiensis Blkr.

Apogon sangiensis Bleeker, Bijdr. Ichth. Sangi, Nat. T. Ned. Ind. XIII p. $3 \% 5$.

Apoğgon sangiensis Günther, Fische d. Südsee, I p. 20.

Apogon sangiensis Day, Fishes of India, 4". p. 64, Plate XVII fig. 3.

Amia sangiensis Bleeker, Atl. Ichth. VII p. 95.

Beo, Majalibit-bay, Waigeu, January 1910, 92 spec. 70—44 mm.

In the original description of this fish, Bleeker says that his single specimen was in a rather bad state of preservation and that the pearl-blue ocelli on the anal fin seem to be present on the second dorsal and caudal too (Bleeker says: dorsal and anal, but this is surely a misprint for dorsal and caudal). This is the case in a good number of my specimens, in others the ocelli are less distinct. 
All my specimens have the tront part of the first dorsal black, which is not mentioned by Bleeker, who states: "dorsali spinosa fusco-arenata". Day says: "Upper half of first dorsal black", while Günther's specimens of Yap are in accordance with mine: "Der vordere Rand der ersten Rückenflosse schwarz".

Day says that there is "a minute black spot on the back, close behind the base of the last dorsal ray". All my specimens show this spot clearly and besides they have a similar spot in front of the first dorsal and between the two dorsal fins.

In other respects my specimens agree with Bleekers diagnosis. The pectorals and ventrals only seem to be slightly shorter.

6. Apogon savayensis Gthr.

Apogon savayensis Günther, Pr. Zool. Soc. 18\%1, p. 656, Fische der Südsee, I p. 21.

Amia savayensis Steindachner, Sitzb. Akad. Wien, CXV p. $13 \% 9$.

Amia savayensis Jordan \& Seale, Bull. Bur. Fish. XXV p. 239.

Saonek, 12 specimens, 85-14 mm.

Bleeker identified this species with his $A$. bandanensis, probably on account of Day's A. savayensis, which seems to me not to be identical with Günther's species of the same name. Klunzinger went still farther and united $A$. moluccensis, hoevenii and monochrous with the two named above.

\%. Apogon margaritophorus Blkr.

Apogon margaritophorus Bleeker, Nat. Tijdschr. Ned. Indië, VII p. 363.

Amia margaritophora Bleeker, Atl. Ichth. VII p. 91.

One specimen, $45 \mathrm{~mm}$, from the fishmarket at Macassar, March 11. 1910.

8. Apogon amboinensis Blkr.

Apogon amboinensis Bleeker, Vierde bijdr. ichth. Amboina, Nat. Tijdschr. Ned. Indië, V p. 329. Amia amboinensis Bleeker, Atl. Ichth. VII p. 90.

River Waiu waigé, Waigeu, in fresh water but still under influence of the tide, 2 spec. \%6-69 mm. 25 Dec. 1909.

My specimens have besides the markings, peculiar to this species, two black spots on the praeoperculum, not mentioned by Bleeker. On the figure in the Atlas Ichth., where erroneously the first dorsal has 7 spines, a reddish band is drawn on the preaoperculum, not mentioned in the text.

9. Apogon melas Blkr.

Apogon melas Bleeker, Contr. ichth. Sumbawa, Journ. Ind. Arch. I p. 635.

Amia melas Bleeker, Atl. Ichth. VII p. 94.

Waigeu, Majalibit-bay, Jan. 1910, 5 spec. 101-115 mm.

Bleeker does not mention in his description of this fish an oblique black stripe, running from the hindmargin of the eye to the intramarginal crest of the praeoperculum, although it is visible in the figure of the fish on Plate 348, fig. 1 of the Atl. Ichth. It is clearly visible in all my specimens.

10. Apogon polystigma (Blkr.). Apogonichthys polystigma Bleeker, Nat. Tijschr. Ned. Ind. VI p. 484. Amia polystigma Bleeker, Atl. Ichth. VII p. 101.

1 spec. $31 \mathrm{~mm}$, Ambon, February 1910.

11. Apogon spec. juv.

Y spec, about $10 \mathrm{~mm}$ long, from brackish water at Kairatu, W. Ceram, February 16. 1910.

D. VI. I 9. A. II 9? 
The body being pigmented is brown, the tail and head are colourless. First dorsal dark brown, a black spot at base of caudal. I am not able to range these young fishes under any of the known species.

$$
\text { Cheilodipterus Lacépède. }
$$

1. Cheilodipterus lineatus (Forsk.).

Perca lineata Forskål, Descript. Animal. p. 42.

Cheilodipteruis lineatus Klunzinger, Fische Roth. Meer. $4^{\circ}$ p. 23.

2 spec., 60 and $63 \mathrm{~mm}$, from Buton, collected by Dr. Justesen.

The two specimens are characterized by the maxillary not reaching to below the hindborder of the eye, by having well developed canini in the jaws and in being rather slender, the height of the caudal peduncle being $\frac{1}{2}$ of its length. The specimens are coloured as C. quinquelineatus, having a black spot at the base of the tail and 5 well defined longitudinal bands; but between these bands there are smaller and lighter ones, so that there are about 8 bands on each side. It is possible that $C$. quinquelineatus, with which species my specimens agree otherwise, is only a variety of $C$. lineatus. Klunzinger says about this question: „Diese Form ( $C$. quinquelineatus) würde ich, wenn nicht Bleeker 54-110"' als Grösse angäbe, für die Jugend von Ch. lineatus halten, mit nog weniger entwickelten Zähnen." Hitherto $C h$. lineatus has not been recorded from the indo-australian archipelago.

2. Cheilodipterus singapurensis Blkr.

Cheilodipterus singapurensis Bleeker, Natuurk. Tïdschr. Ned. Indië, XX p. 452.

Paramia singapurensis Bleeker, Nat. Verh. Mpij v. Wetensch. $3^{\text {de }}$ Verz. II p. \%8. Atl. Ichth. VII p. 106.

21 spec., 165-65 mm, Beo, Majalibit-bay, Waigeu, January 1910.

My specimens only differ from Bleeker's description in the coloration. They are all dark brown, with four still deeper brown longitudinal stripes, the first running from the beginning of the lateral line to the caudal fin, where it is continued on the upper margin of the fin. The second runs from the snout through the eye to the middle of the base of the caudal fin, where it ends in a black patch, not always distinct. The third begins also at the snout, runs over the dorsal part of the maxilla, through the base of the pectoral fin to the lower margin of the caudal fin, where it may faintly be traced on the lower rays. The fourth is rather indistinct, and runs from the corner of the mouth to the anal fin. In the half of my specimens there is a silvery white patch on the opercle, between the second and the third longitudinal stripe. First dorsal, basal half of second dorsal, caudal and ventrals dark.

$$
\text { Lutjanus Bloch. }
$$

1. Lutjanus ehrenbergi (Pet.).

Mesoprion Ehrenbergi Peters, Monatsber. Akad. Berlin 1869, p. $\% 04$.

Lutjanus oligolepis Bleeker, Atl. Ichth. VIII p. 48.

Mesoprion Ehrenbergi Klunzinger, Fische Roth. Meeres. $4^{\circ}$ p. 13.

One specimen $62 \mathrm{~mm}$, from Batu merah, Ambon, March 1910.

2. Lutjanus biguttatus (C. V.).

Serranus biguttatus Cuvier \& Valenciennes, Hist. Nat. Poiss. VI p. $50 \%$.

Lutjanus Bleekeri Günther, Cat. Brit. Mus. I p. 208.

Lutjanus biguttatus Bleeker, Atl. Ichth. VIII p. 54.

Lutjanus biguttatus Day, Fishes of India. $4^{\circ}$ p. 34.

12 spec. $80-120 \mathrm{~mm}$, from the Majalibit-bay, Waigeu, January 1910.

2 spec. $162-165 \mathrm{~mm}$, Ambon, Batu merah, February 1910. 
3. Lutjanus kasmira (Forsk.).

Sciaena kasmira Forska1, Descr. Anim. p. 46.

Lutjanus bengalensis Bleeker, Atl. Ichth. VIII p. 55.

Lutjanus quinquelineatus Bleeker, Atl. Ichth. VIII p. 56.

Lutjanus kasmira Max Weber, Siboga-Exp. Fische, p. 248.

1 spec., $191 \mathrm{~mm}$, from the fishmarket at Buton, December 3. 1909.

2 spec., 158-170 mm, Ambon, February-March 1910.

4. Lutjanus gibbus (Forsk.).

Sciaena gibba Forskål, Descript. Animal. p: 46.

Lutjanus butonensis Bleeker, Atl. Ichth. VIII p. 59.

1 spec., $74 \mathrm{~mm}$. from the fishmarket at Ambon, December \%. 1909.

5. Lutjanus fulviflamma (Forsk.).

Sciaena fulviflamma Forskal, Descript. Animalium, p. 45.

Lutjanus fulviflamma Bleeker, Atl. Ichth. VIII p. 65.

2 spec., 218 and $235 \mathrm{~mm}$, from Sanana, Sula Islands, December 10. 1909.

6. Lutjanus marginatus (C. V.).

Diacope marginata Cuvier \& Valenciennes, Hist. Nat. Poiss. II p. 425.

Lutjanus flavipes Bleeker, Atl. Ichth. VIII p. 68.

Lutjanus marginatus Bleeker, Atl. Ichth. VIII p. 69.

Lutjanus marginatus Max Weber, Siboga-Exp. Fische, p. 252.

1 spec., $2 \% 0 \mathrm{~mm}$, from Sanana, Sula Islands, December 10. 1909.

1 spec., $190 \mathrm{~mm}$, from Ambon, February 1910.

\%. Lutjanus monostigma (C. V.).

Mesoprion monostigma Cuvier \& Valenciennes, Hist. Nat. Poiss. II. p. 446.

Lutjanus lioglossis Bleeker, Atl. Ichth. VIII p. 70.

A specimen, long $173 \mathrm{~mm}$, from Saonek and another young one of $48 \mathrm{~mm}$, from the reef at the same island.

A specimen from Batu merah, Ambon, $76 \mathrm{~mm}$ long, may belong to this species. It shows however a dark band, running from the snout through the eye to the blotch under the soft dorsal, and continued from there to the caudal. Parallel to and below this band runs another one, beginning under the eye. Another band runs from the hindborder of the eye to the beginning of the soft dorsal, above which runs a band from the upperborder of the eye to the middle of the spinous dorsal. The space between the two lower bands is margaritaceous, as well as a ring round the blotch under the soft dorsal. Upperborder of dorsal blackish.

The specimen is not very well preserved and the exact number of scales on the praeoperculum could not be ascertained, but in general shape etc. it closely resembles $L$, monostigma. I suppose that it is a variety of this species, as another specimen from Ambon, long $45 \mathrm{~mm}$, shows a band through the eye, continued on the operculum, but has the body without bands as in $L$. monostigma.

8. Lutjanus rivulatus (C. V.).

Diacope rivulata Cuvier \& Valenciennes, Hist. Nat. Poiss. II p. 414.

Lutjanus rivulatus Bleeker, Atl. Ichth. VIII p. 73.

1 spec., $88 \mathrm{~mm}$, frorn the fishmarket at Macassar, March 11. 1910.

9. Lutjanus argentimaculatus (Forsk.).

Sciaena argentimaculata Forskål, Descript. Animal. p. 4\%.

Lutjanus argentimaculatus Bleeker, Atl. Ichth. VIII p. 74. 
3 spec., 31-142 mm, Batu merah, Ambon, February 1910.

1 spec., $102 \mathrm{~mm}$, Buli, Halmahera, fresh water (Mission. Maan leg.).

Two young specimens of $25 \mathrm{~mm}$, from the river Mirdika, Ambon, Dec. \%. 1909, and a still younger one, $20 \mathrm{~mm}$ long, from the mouth of the Riuapa river, Kairatu, Ceram, probably belong to this species. They are characterised by a long slender spine at the angle of the praeoperculum, which is longer in the smaller specimen than in the two other ones.

Lutjanus spec. juv.

1 spec., $28 \mathrm{~mm}$, from the reef at Saonek, January 1910.

Therapon Cuvier.

1. Therapon jarbua (Forsk.).

Sciaena jarbua Forskâl, Descript. Animal. p. 50.

Therapon servus Günther, Cat. Brit. Mus. I p. 278.

Therapon (Datnia) jarbua Bleeker, Atl. Ichth. VII p. 112.

Therapon jarbua Day, Fishes of India $4^{\circ}$. p. 69.

Therapon jarbua Klunzinger, Fische Roth. Meer. $4^{\circ}$. p. 26.

3 spec., 140-185 mm, Kairatu, W. Ceram, March 1. 1910.

1 spec., $70 \mathrm{~mm}$, Batu merah, Ambon, March 1910 .

2. Therapon puta C. V.

Therapon puta Cuvier \& Valenciennes, Hist. Nat. Poiss. III p. 131.

Therapon vittatus Günther, Cat. Brit. Mus. I p. 280 (vittatus H. B. ?)

Therapon (Datnia) puta Bleeker, Atl. Ichth. VII p. 112.

Therapon puta Day, Fishes of India $4^{\circ}$. p. 68.

Therapon puta Klunzinger, Fische Roth. Meeres $4^{\circ}$. p. 26.

15 spec., 93-112 mm, Majalibit-bay, Waigeu, January 1910.

3. Therapon argenteus (C. V.).

Datnia argentea Cuvier \& Valenciennes, Hist. Nat. Poiss. III p. 139.

Therapon argenteus Günther, Cat. Brit. Mus. III p. 283.

Therapon (Datnia) argenteus Bleeker, Atl. Ichth. VII p. 114.

Datnia argentea Day, Fishes of India $4^{\circ}$ : p. 71.

1 spec., $235 \mathrm{~mm}$, from Kairatu, W. Ceram, March, 1. 1910.

4. Therapon rosenbergii (Blkr.).

Datnia Rosenbergii Bleeker, Nat. Tijdschr. Ned. Indië XXII p. $23 \%$.

Therapon (Datnia) Rosenbergii Bleeker, Atl. Ichth. VII p. 116.

1 spec., $215 \mathrm{~mm}$, river Batu Merah, Ambon, December \%. 1909, fresh water.

l'spec., $180 \mathrm{~mm}$, river at Batjan, December 11. 1909, fresh water.

Both specimens are better in accordance with the description of Th. rosenbergii than of Th. cancellatus. The first mentioned specimen has, however, much stronger spines on the angle of the praeoperculum than the other smaller specimen and agrees in this respect with Th. cancellatus. 'I'he differences between these two species are very slight and I have little doubt that, at the hand of more material than I dispose of at present, both species could be united.

The carnosity of the upperlip is much more marked in my specimens than in the figure of Bleeker in the Atlas Ichthyologique. It gives the snout a pig-like appearance, quite different from that of other" species of the genus. 
Pseudochromididae.

Opisthognathus Cuv.

1. Opisthognathus (Gnathypops) spec.

1 spec., $29 \mathrm{~mm}$, from the reef at Saonek, December 1909.

It is impossible to determine the species, as the scales are still invisible, except on the tail.

Pseudochromis Rüppell.

1. Pseudochromis fuscus Müll. Trosch.

Pseudochromis fuscus Müller \& Troschel, Horae ichthyol. III p. 23.

Pseudochromis xanthochir Bleeker, Nat. Tijdschr. Ned. Indië VIII p. 443. Verh. Akad. Amsterdam, XV, Pseudochromidoïdes, p. $1 \%$.

Pseudochromis fuscus Bleeker, Verh. Akad. Amsterdam XV, Pseudochromidoïdes, p. 16.

3 spec., 65-36 mm, Ambon, February 1910.

The smaller specimen misses the dark band at the caudal and at the base of the pectorals and should therefore be what Bleeker calls: $P$. xanthochir. As this is the only difference between both species, I think that one may look at $P$. xanthochir as a synonym of $P$. fuscus.

2. Pseudochromis melanotaenia Blkr.

Pseudochromis melanotaenia Bleeker, Ned. Tijdschr. Dierk. 1, p. 273. Verh. Kon. Akad. Amsterdam, XV, Pseudochromidoïdes, p. 20.

1 spec., $34 \mathrm{~mm}$, from Ambon, F'ebruary 1910.

The coloration of my specimen does not quite agree with that of Bleeker's 2 specimens, (one from Timor and the ather from Ambon). The black stripe on the dorsal is continuous with that of the caudal and is prolonged in front on the bead, so that the whole system of coloration may be described as follows: Head and body yellowish, minutely spotted with brown, more densely on some of the scales on the side, so as to form brown patches. A dark brown almost black band beginning at the snout covers the iutraorbital space and runs backward along the dorsal fin, leaving only its upperpart hyalin, continued on the dorsal side of the tail and the upper margin of the caudal fin, where it descends to the lower margin in the form of a semicircle, which touches the nearly straight hinder margin of the caudal fin. The band, running forward along the lower margin of the caudal fin, ends at the hinder margin of the anal.

\section{Pseudogram ma Bleeker.}

1. Pseudogramma polyacanthus (Blkr.).

Pseudochromis polyacanthus Bleeker, Nat. Tijdschr. Ned. Indië X p. 375.

Pseudochromis polyacanthus Bleeker, Verh. Kon. Akad. v. Wetensch. XV p. 25.

3 spec., 28 and $43 \mathrm{~mm}$ long, from Ambon, January and February 1910, in corals.

$$
\text { Sillaginilae. }
$$

Sillago Cuvier.

1. Sillago sihama (Forsk.).

Atherina sihama Forskål, Descript. Animal. p. 70.

Sillago sihama Bleeker, Verh. Akad. Amsterdam XIV; Sciénoid. et Sillag. p. $6 \%$.

6 spec., 79-133 mm, Ambon, Batu merah, February and March 1910. 
2. Sillago macrolepis Blkr.

Sillago macrolepis Bleeker, Nat. Tijdschr. Ned. Indië XVIII p. 166. Verh. Akad. Amsterdam, XIV p. 72.

1 spec., $90 \mathrm{~mm}$, Saonek, January 1910 .

2 spec., 93 and $112 \mathrm{~mm}$, Ambon, February 1910.

Gerridae.

Equula Cuvier.

1. Equula edentula (B1.).

Scomber edentulus Bloch, Ausländ. Fische IX p. 108.

Equula ensifera Cuvier \& Valenciennes, Hist. Nat. Poiss. X p. 66.

Equula ensifera Bleeker, Verh. Bat. Gen. XXIV Makreel. p. 80.

Equula edentula Günther, Cat. Brit. Mus. II p. 498.

2 spec., 112 and $125 \mathrm{~mm}$, from mouth of river at Buton, December 3.1909 (brackish).

2. Equula splendens Cuv.

Equula splendens Cuvier, Règne Animal II p. 212.

Equula gomorah Cuvier \& Valenciennes, Hist. Nat. Poiss. X p. 80.

Equula gomorah Bleeker, Verh. Bat. Gen. XXIV. Makreel. p. 82.

Equula splendens Günther, Cat. Brit. Mus. II p. 501.

6 spec., $70-80 \mathrm{~mm}$, from the fishmarket at Macassar, March 11. 1910.

3. Equula daura Cuv.

Equula daura Cuvier, Rèyne Animal II p. 212.

Equula dacer Cuvier \& Valenciennes, Hist. Nat. Poiss. X p. 83.

Equula dacer Bleeker, Verh. Bat. Gen. XXIV. Makreel. p. 81.

Equula daura Günther, Cat. Brit. Mus. II p. 502.

Many specimens, 43-110 mm, from Amboina, February 1910.

1 spec., about $60 \mathrm{~mm}$, from Buton (Dr. Justesen leg.).

4. Equula oblonga C. V.

Equula oblonga Cuvier \& Valenciennes, Hist. Nat. Poiss. X p. 85.

Equula oblonga Bleeker, Verh. Bat. Gen. XXIV. Makreel. p. 84.

Equula oblonga Günther, Cat. Brit. Mus. II p. 502.

1 spec., $14 \mathrm{~mm}$, from the fishmarket at Macassar, March 11. 1910.

Gazza Rüppell.

1. Gazza argentaria (Forster).

Zeus argentarius Forster, Descr. Anim. p. 288.

Gazza argentaria Max Weber, Siboga-Exp. Fische, p. 270.

13 spec., 50-95 mm, from the Majalibit-bay, Waigeu. January 1910.

1 spec., $100 \mathrm{~mm}$, from Ambon, February 1910.

Gerres Cuvier.

1. Gerres filamentosus C. V.

Gerres filamentosus Cuvier \& Valenciennes, Hist. Nat. Poiss. VI p. 482.

Diapterus filamentosus Bleeker, Atl. Ichth. VIII p. 124.

1 spec., $115 \mathrm{~mm}$, from Bajon, Waigeu, January 9. 1910. 
2. Gerres macracanthus Blkr.

Gerres macracanthus Bleeker, Nat. Tijdschr. Ned. Indië, VI p. 195.

Diapterus macracanthus Bleeker, Atl. Ichth. VIII p. 125.

2 spec., from Ambon, Batu merah, March 1910.

Bleeker never got this species from the Moluccos and thought that it was restricted to the western part of the Indo-Australian Archipelago. My specimens however prove the reverse. Both show the transversal bands mentioned by Bleeker very clearly and accord in every other respect with Bleeker's description.

3. Gerres macrosoma Blkr.

Gerres macrosoma Bleeker, Nat. Tijdschr. Ned. Indië, VI p. 56.

Diapterus macrosoma Bleeker, Atl. Ichth. VIII p. 126.

3 spec., 10-95 mm, Saonek, December 18. 1909.

4. Gerres oyena (Forsk.).

Latrus oyena Forskål, Descr. Anim. p. 35.

Diapterus oyena Bleeker, Atl. Ichth. VIII p. 129.

2 spec., about $100 \mathrm{~mm}$, Majalibit-bay, Waigeu, January 1910.

Pristipomatidae.

Emmelichthys Richardson.

1. Emmelichthys leucogrammicus (Blkr.).

Dipterygonotus leucogrammicus Bleeker, Journ. Ind. Arch. III 1849 p. \%1. - Atl. Ichth. VIII p. 42.

2 spec., 67 and $70 \mathrm{~mm}$, from the fishmarket at Buton, December 3. 1909.

\section{Pentapus C.V.}

1. Pentapus nemarus (Blkr.).

Heterognathodon nemurus Bleeker, Nat. Tijdschr. Ned. Indië, III p. 754.

Heterognathodon nemurus Günther; Cat. Brit. Mus. I p. 365.

Pentapus nemurus Bleeker, Atl. Ichth. VIII p. 103.

1 spec., $168 \mathrm{~mm}$, from Saonek, January 21. 1910.

In life this specimen was bright lilac, lighter below; the upper part of the head bright yellow. From the yellow of the head two longitudinal bands extend to the tail, both are margined with brown. The upper one, which is the narrower, runs above the lateral line just below the base of the dorsal fin, and does not extend farther than the tail. The lower , one runs in a straight line from head to base of caudal, which is also yellow in the middle.

Plectorhynchus Lacépède.

1. Plectorhynchus chaetodonoides Lac.

Plectorhynchus chaetodonoides Lacépède, Hist. Nat. Poiss. III p. 135.

Diagramma chaetodonoides Günther, Cat. Brit. Mus. I p. 326.

Plectorhynchus chaetodonoides Bleeker, Atl. Ichth. VIII p. $1 \%$

2 spec., 82 and $345 \mathrm{~mm}$, from Ambon, February 1910. 
2. Plectorhynchus goldmanni Blkr.

Diagramma Goldmanni Bleeker, Nat. Tijdschr. Ned. Indië IV p. 602.

Plectorhynchus Goldmani Bleeker, Atl. Ichth. VIII p. 21.

1 spec., $460 \mathrm{~mm}$, from Sanana, Sula Islands, December 10. 1909.

3. Plectorhynchus orientalis (B1.).

Anthias orientalis Bloch, Ausländ. Fische VII p. 10.

Plectorhynchus orientalis Bleeker, Atl. Ichth. VIII p. 22.

1 spec., 142 mm, from Ambon, February 1910.

1. Scolopsis ciliatus (Lac.).

\section{Scolopsis Cuvier.}

Holocentrus ciliatus Lacépède, Hist. Nat. Poiss. IV p. 333.

Scolopsis ciliatus Bleeker, Atl. Ichth. VIII p. 6.

1 spec., $9 \% \mathrm{~mm}$ long, from the fishmarket at Macassar, March 11. 1910.

2. Scolopsis temporalis C. V.

Scolopsis temporalis Cuvier \& Valenciennes, Hist. Nat. Poiss. V p. 341.

Scolopsis temporalis Günther, Cat. Brit. Mus. I p. 360.

Scolopsis temporalis Bleeker, Atl. Ichth. VIII p. 12.

1 spec., about $240 \cdot \mathrm{mm}$, from Ambon, February 1910.

My specimen differs from Günther's description in the following points: there are only 5 scales above the lateral line, the snout is somewhat longer than the diameter of the eye, which is equal to the height of the praeorbital. The characteristic markings of this species as well as the peculiar scaleless supraorbital space leave no doubt that my specimen belongs to the above-named species. It seems to be rare, as Bleeker never saw a specimen from the Indo-Australian Archipelago.

3. Scolopsis elongatus M. Web.

Scolopsis elongatus Max Weber, Siboga-Exp. Fische, p. 281.

3 spec., 80-114 mm, from Saonek.

1. Synagris ruber (C. V.).

$$
\text { Synagris Günther. }
$$

Dentex ruber Cuvier \& Valenciennes, Hist. Nat. Poiss. VI p. $24 \%$.

Dentex ruber Lesson, Voyage Coquille p. 18\%. Pl. XXXI fig. 2.

Synagris ruber Bleeker; Atl. Ichth. VIII p. 84.

1 spec., $90 \mathrm{~mm}$, from the fishmarket at Macassar, March 11. 1910.

My specimen has the praeorbital formed as on the figure of Lesson, the free border of the praeoperculum is smaller than the scaled part and the two last dorsal spines. are shorter than the preceding ones. The combination of these characters makes it probable that my specimen belongs to the same species as those that were examined by Cuvier \& Valenciennes and Lesson and called Dentex ruber. Bleeker did not see this species. Future research will have to make out, if it is different from Synagris taeniopterus (C. V.).

1. Caesio maculatus C. V.

$$
\text { Caesio Comm. }
$$

Caesio maculatus Cuvier \& Valenciennes, Hist. Nat. Poiss. VI p. 439.

Caesio maculatus Günther, Cat.'Brit. Mus. I p. 391.

Caesio maculatus Bleeker, Atl. Ichth. VIII p. 38.

Caesio maculatus Max Weber, Siboga-Exp. Fische, p. 285. 
1 spec., $105 \mathrm{~mm}$, Majalibit-bay, Waigeu, January 1910.

1 spec., $141 \mathrm{~mm}$, Ambon, February 1910.

2. Caesio spec.

A small, badly preserved specimen of $55 \mathrm{~mm}$, from Buton, belongs to the above-named species or to the allied $C^{\gamma}$. caerulaureus Lac.

Gymnocaesio Bleeker.

1. Gymnocaesio gymnopterus · (Blkr.).

Caesio gymnopterus Bleeker, Nat. Tijdschr. Ned. Indië X p. 372.

Gymnocaesio gymnopterus Bleeker, Atl. Ichth. VIII p. 34.

1 spec., $114 \mathrm{~mm}$, from the fishmarket at Ambon, December \%. 1909.

Lethrinus Cuvier.

1. Lethrinus moensi Blkr.

Lethrinus Moensi Bleeker, Nat. Tijdschr. Ned. Indië IX p. 435.

Lethrinus moensi Günther, Fische der Südsee I p. 64.

Lethrinus Moensi Bleeker, Atl. Ichth. VIII p. 115.

2 spec., 218 and $250 \mathrm{~mm}$, Sanana, Sula-Islands, December 9. 1909.

2. Lethrinus opercularis (C. V.) Blkr.

$?$ Lethrinus opercularis Cuvier \& Valenciennes, Hist. Nat. Poiss. II p. 289.

Lethrinus opercularis Bleeker, Atl. Ichth. VIîI p. 119.

1 spec., $115 \mathrm{~mm}$, from Saonek.

1 spec., $92 \mathrm{~mm}$, fishmarket at Macassar, March 11. 1910.

Mullidac.

Upeneus (Cuvier) Blkr.

1. Upeneus sulphureus C. V.

Uperieus sulphureus Cuvier \& Valenciennes, Hist. Nat. Poiss. III p. 450.

Upeneus sulphureus Bleeker, Verh. Akad. Amsterdam 18 $\mathbf{1 4}$, Révis. Mulloïdes, p. 4.

1 spec., $146 \mathrm{~mm}$, Kairatu, W. Ceram, February 28. 1910.

2. Upeneus vittatus (Forsk.).

Mullus vittatus Forskål, Descript. Anim. p. 31.

Upeneus vittatus Bleeker, Verh. Akad. Amst. 18\%4. Rév, Mulloïdes, p. 6.

9 spec., 87-100 mm, Kairatu, W. Ceram, February 28. 1910.

1 spec., $57 \mathrm{~mm}$, Ambon, February 1910 (bad condition).

1 spec., $81 \mathrm{~mm}$. Buton, Dr. Justesen leg.

3. Upeneus sundaicus (Blkr.).

Upeneoides sundaicus Bleeker, Act. Soc. Scient. Ind. Neerl. Achtste bijdr. vischf. Ambon, p. 4\%.

Upeneus sundaicus Bleeker, Verh. Akad. Amst. 18\%4. Révis. Mụlloïdes, p. 10.

1 spec., $110 \mathrm{~mm}$, fishmarket at Makassar, March 11. 1910.

My specimen has the lower lobe as well as the upper lobe of the caudal fin banded. In all other respects it agrees with the description given by Bleeker. 
4. Upeneus tragula Rich.

Upeneus tragula Richardson, Rep. Ichth. China, Rep. 15th Meeting Brit. Assoc. p. 220.

Upeneus tragula Bleeker, Verh. Akad. Amst. 1874. Révis. Mulloïdes, p. 11.

1 spec., $135 \mathrm{~mm}$, probably from Sorong, N. Guinea.

\section{Mulloides Bleeker.}

1. Mulloides samoensis Gthr. Mulloides samoensis Günther, Fische der Südsee, p. $5 \%$. Mulloides samoensis Jordan \& Evermann, Bull. Fish. Comm. XXIII p. 253. Mulloides samoensis Max Weber, Siboga-Exp. Fische, p. 294.

1 spec., $185 \mathrm{~mm}$, from the fishmarket at Ambon, December \%. 1909.

Parupeneus Bleeker.

1. Parupeneus indicus (Shaw).

Mullus indicus Shaw, Gen. Zool. IV, 2 p. 614.

Upeneus indicus Günther, Cat. Brit. Mus. I p. 406, Fische der Südsee, p. 5\%.

Upeneus malabaricus Günther, Cat. Brit. Mus. I p. 40\% - Fische der Südsee, p. 58. Parupeneus indicus Bleeker, Verh. Akad. Amst. 18\%4. Révis. Mulloïdes, p. 28.

Pseudupeneus indicus Snyder, Proc. U. S. Nat. Mus. XXXII p. 93.

One specimen, about $250 \mathrm{~mm}$, from Ambon, February 1910, has the eye situated in the hinderpart of the head as in P. malabaricus (Günther), but has the short barbels of $P$. indicus.

\section{Chaetodontidae.}

\section{Scatophagus Cuvier.}

1. Scatophagus argus (Bl.).

Chaetodon argus Bloch, Ausländ. Fische III p. 86.

Ephippus argus Bleeker, Verh. Akad. Amsterdam XVII p. 26. Atl. Ichth. IX p. 21.

1 spec., $63 \mathrm{~mm}$, river Batu merah, Ambon, December 6. 1909.

3 spec., 17-19 mm, Kairatu, West Ceram, brackish water.

The last-named specimens are still in larval condition, having remains of the Tholichthys stadium.

\section{Chaetodon L.}

1. Chaetodon auriga Forsk.

Chaetodon auriga Forskal, Descript. Animal. p. 60.

Tetragonoptrus auriga Bleeker, Atl. Ichth. IX p. $4 \%$.

1 spec., 119 mm, Sorong, New Guinea, January 1910 (L. de Bruyne leg.).

2. Chaetodon kleinii $\mathrm{Bl}$.

Chaetodon Kleinii Bloch, Ausländ. Fische·IV p. \%.

Tetragonoptrus Kleinii Bleeker, Atl. Ichth. IX p. 45.

2 spec., 50-65 mm, from the fishmarket at Ambon, December \%. 1909.

3. Chaetodon vagabundus $\mathrm{L}$.

Chaetodon vagabundus Linné, Syst. Nat. ed. $10 a$ p. 276.

Tetragonoptrus vagabundus Bleeker, Atl. Ichth. IX p. 48.

3 spec., 111-126 mm, Sorong, New Guinea, January 1910 (L. de Bruyne leg.). 
Parachaetodon Bleeker.

1. Parachaetodon ocellatus (C. V.).

Platax ocellatus Cuvier \& Valenciennes, Hist. Nat. Poiss. VII p. 229.

Parachaetodon ocellatus Bleeker, Atl. Ichth. IX p. 24.

1. spec., $57 \mathrm{~mm}$, from the fishmarket at Ambon, March 11. 1910.

Chelmon Cuvier \& Valenciennes.

1. Chelmon rostratus (L.).

Chaetodon rostratus Linné, Mus. Ad. Fried. I p. 61.

Chelmo rostratus Bleeker, Atl. Ichth. IX p. 22.

2 spec., $125 \mathrm{~mm}$, Sorong, New Guinea, January 1910. L. de Brayne leg.

Heniochus Cuvier \& Valenciennes.

1. Heniochus acuminatus (L.).

Chaetodon acuminatus Linné, Syst. Nat. ed. X p. 2 \%2.

Heniochus acuminatus Bleeker, Atl. Ichth. IX p. 29.

2 spec., $125 \mathrm{~mm}$, Sorong, New Guinea, January 1910. L. de Bruyne leg.

Holacanthus Lacépède.

1. Holacanthus semicirculatus C. V.

Holacanthus semicirculatus Cuvier \& Valenciennes, Hist. Nat. Poiss. VII p. 143.

Acanthochaetodon semicirculatus Bleeker, Nat. Verh. Ak. Amsterdam, XVII p. 146. Atl. Ichth. IX p. 69.

1 spec., $19 \mathrm{~mm}$, Saonek, reef.

My very young specimen has besides the medial stripe between the eyes, only two more stripes on the head and two on the body, in accordance with Bleeker's description of the juveniles of this species. The soft part of the dorsal and anal has a white margin, and the caudal is quite white, without stripes or bands.

\section{A canthuridae.}

Acanthurus Bl. Schn.

1. Acanthurus blochii C. V.

Acanthurus blochii Cuvier \& Valenciennes, Hist. Nat. Poiss. X p. 209.

Acanthurus blochii Günther, Fische der Südsee I p. 109.

1 spec., $52 \mathrm{~mm}$, Batu merah, Ambon, March 1910.

An Acronurus, from the same locality, possibly belongs to this species.

$\mathrm{N}$ ase us Commerson.

1. Naseus spec. juv. (Keris-stadium).

Keris amboinensis Bleeker, Nat. Tijdschr. Ned. Indië III p. 272.

Keris. amboinensis Günther, Cat. Brit. Mus. III p. 356.

2 spec., 60-75 mm, Ambon, fishmarket, December \%. 1909.

8 spec., 38-61 mm, Ambon, February 1910. 
I am not sure if the young Naseus mentioned above are identical with Bleeker's Keris amboinensis. The smaller ones, being of the same length as those described by Bleeker ( 44 and $52 \mathrm{~mm}$ ), fully agree in measurements, but the larger ones are less high, a difference very possibly due to age. There is some diversity in the colouring of the soft dorsal fin. In some individuals: "dorsali radiosa et anali fuscis vitta longitudinali media grisea" in others the fin has a light colour with two or three parallel darker bands. One specimen has a dark submarginal and a clear white marginal band along the dorsal and anal fin, as well as a bright white marginal band along the caudal.

2. Naseus spec. juv. (Keris-stadium).

1 spec., $54 \mathrm{~mm}$, Ambon, February 1910.

D. VI. $2 \%$ A. II. $2 \%$.

This specimen may be at once distinguished from the different $K$ eris, hitherto described, by its elongate form, the height being contained $33 / 5$ times in the total length, or 3 times in the length without caudal. The head is as long as high, 1/4 of the total length (the caudal included). The eye is placed far backwards, much nearer to the hinder margin of the operculum than to the tip of the snout. Its diameter is $2 / 3$ of the length of the head. Colour yellowish brown, the dorsal, anal and ventral fins dark. The caudal has a broad, curved white band at its base, in the form of a 3, followed by some smaller black and white bars, which are not very distinct.

\section{Zanclus Lacépède.}

1. Zaniclus cornutus (L.).

Chaetodon cornutus Linné, Syst. Nat. ed. X p. 243.

Zanclus cornutus Bleeker, Atl. Ichth. IX p. $7 \%$.

1 spec., 74 mm, Ambon, February 1910.

\section{Amphacanthidae.}

Amphacanthus Bl. Sch.

1. Amphacanthus javus (L.).

Teuthis javus Linné, Syst. Nat. ed. ẊII p. $50 \%$.

Amphacanthus javus Cuvier \& Valenciennes, Hist. Nat. Poiss. X p. 118.

Amphacanthus javus Bleeker, Verh. Bat: Gen. XXIII p. 9.

Teuthis javus Günther, Cat. Brit. Mus. III p. 315.

2 spec., 152 and $158 \mathrm{~mm}$, Beo, Majalibit-bay,'Waigeu, January 1910.

2. Amphacanthus vermiculatus C. V.

Amphacanthus vermiculatus Curier \& Valenciennes, Hist. Nat. Poiss. X p. 126.

Amphacanthus vermiculatus Bleeker, Verh. Bat. Gen. XXIII p. 11.

Teuthis vermiculata Günther, Cat. Brit. Mus. III p. $31 \%$.

1 spec., $2 \% 0 \mathrm{~mm}$, Buli, Halmahera, December 15.1909.

1 spec., $130 \mathrm{~mm}$, Batu merah, Ambon, February 1910.

3. Amphacanthus striolatus (Gthr.).

Teuthis striolata Günther, Cat. Brit. Mus. III p. 319.

Teuthis striolata Günther, Fische der Sridsee, p. 89.

Two specimens, $11 \%$ and $15 \% \mathrm{~mm}$, from Saonek, probably belong to this species, although they differ slightly in colour with Günther's description. My specimens are of a deep chocolatebrown, indistinctly vermiculated with whitish. Region between pectorals and ventrals white, 
as if these parts were covered with chalk. Cheeks, operculum and under surface of head also tinged with white. Tail chocolate-brown in the basal half, yellowish, with indistinct bars in the outer half. Anal and soft dorsal yellow, the rays brown, spotted with darker brown. Pectorals yellow, brown at their base. Ventrals brown, with the same „chalked" appearance as the surrounding parts of the body:

\section{Pomacentridac.}

\section{Pomacentras Lacépède.}

1. Pomacentrus melanochir Blkr.

Pomaoentrus melanochir Bleeker, Versl. Kon. Akad. Amsterd 2de R. X p. 384. Natuurk.

Verh. Holl. 'Mpij. 3de Verz. Deel II, n". 6, p. 49.

3 spec., 69-54 $\mathrm{mm}$, from the fishmarket at Ambon, December \%. 1909.

2. Pomacentrus moluccensis Blkr.

Pomacentrus moluccensis Bleeker, Nat. Tijdschr. Ned. Indië IV p. 118.

Pomacentrus moluccensis Günther, Cat. Brit. Mus. IV p. 30.

Pomacentrus moluccensis Bleeker, Verh. Holl. Mpij. 3de Verz. Deel II, nº 6, p. 56.

13 spec., 19-55 mm, Ambon, February and March 1910.

3. Pomacentrus amboinensis Blkr.

Pomacentrus amboinensis Bleeker, Versl. Kon. Akad. Amsterdam, 2 ${ }^{\text {de }}$ Reeks II p. 334.

Natuurk. Verh. Holl. Mpij. $3^{\text {do }}$ Verz. Deel II $\mathrm{n}^{0}$. 6, p. 58.

I got one specimen, $90 \mathrm{~mm}$ long, on the fishmarket at Ambon, December \%. 1909.

4. Pomacentrus trilineatus C. V.

Pomacentrus trilineatus Cuvier \& Valenciennes, Hist. Nat. Poiss. V p. 428.

Pomacentrus trilineatus Bleeker, Verh. Holl. Mpij. 3de Verz. II n ${ }^{0}$. 6, p. 61 (S. Syn.).

7 spec., 110-125 mm, Ambon, mouth of the Batu merah river, 8 Dec. 1909. February 1910.

1 spec., $57 \mathrm{~mm}$, Ambon, February 1910.

1 spec., $69 \mathrm{~mm}$, Majalibit-bay, Waigeu, January 1910.

1 spec., $90 \mathrm{~mm}$, Buli, Halmahera (Maan leg.).

A young specimen, $34 \mathrm{~mm}$ long, from Ambon, that has partly lost his scales, probably belongs to this species.

5. Pomacentrus fasciatus C. V.

Pomacentrus fasciatus Cuvier \& Valenciennes, Hist. Nat. Poiss. V p. 426.

Dischistodus fasciatus Bleeker, Nat. Verh. Holl. Mpij. 3 ${ }^{\text {de }}$ Verz. Deel II n ${ }^{0}$ 6, p. 86.

2 spec., 118 and $127 \mathrm{~mm}$ long, from Saonek.

Cheiloprion Max Weber.

1. Cheiloprion labiatus (Day).

Pomacentrus labiatus Day, Fishes of India $4^{\circ}$. p. 384.

Cheiloprion labiatus Max Weber, Siboga-Exp. Fische, p. 342.

1 spec., $48 \mathrm{~mm}$ long, from Ambon, February 1910.

A bu defduf Forskal.

1. Abudefduf saxatilis saxatilis (L.).

Chaetodon saxatilis Linné, Syst. Nat. ed. X p. 276. 
Glyphidodon coelestinus Bleeker, Verh. Holl. Mpij. 3dc Verz. II no 6, p. 101. Glyphisodon saxatilis Jordan \& Snyder, Proc. U. S. Nat. Mus. XXIV. p. 608.

1 spec., $170 \mathrm{~mm}$, Sorong, New Guinea. L. de Bruyne leg.

20 young specimens, 23-35 mm, Sionek, January 21. 1910.

2. Abudefduf saxatilis coelestinus (C. V.).

Glyphisodon coelestinus Cuvier \& Valenciennes, Hist. Nat. Poiss. V p. 464.

Glyplidodon coelestinus var. $b$ Bleeker, Verh. Holl. Mpij. 3de Verz. II $\mathrm{n}^{0} .6$, p. 101.

1 spec., $23 \mathrm{~mm}$, Saonek. January 21. 1910.

3. Abudefduf plagiometopon Blkr.

Glyphisodon plagiometopon Bleeker, Nat. Tijdschr. Ned. Indië IIl p. 6\%. .

Glyphidodon plagiometopon Bleeker, Verh. Holl. Mpij. 3 do Verz. II nº. 6, p. 103.

1 spec., $150 \mathrm{~mm}$, from Saonek, January 1910.

As I found some differences between my specimen and those of Bleeker according to his description, I compared it with the type in the Leyden Museum. This examination proved that it certainly belongs to the above-named species, but that the scales on the praeoperculum are not so strictly biserial as in the type. In my specimen some of the vertical rows in the hinder portion consist of 3 scales. The inferior pharyngeal bone does not show the peculiar shape described by Bleeker, but is more or less triangular, with the hinder margin concave. I don't know if much value has to be attached to the characteristics of the pharyngeal bones. It seems that Bleeker is the only ichthyologist who makes use of them as specific characters. At all events I don't think I am justified in making a new species only on this difference with the typical specimina. The colour of my specimen is much darker than in those of Bleeker, but the light stripes and dots on the scales of the back and along the sides are clearly visible.

The tail is rounded in my specimen and not emarginate as described by Bleeker. The two typical specimens in the Leyden Museum however have also the tail more or less rounded.

4. Abudefduf melas (C. V.).

Glyphisodon melas Cuvier \& Valenciennes, Hist. Nat. Poiss. V p. 4\%2.

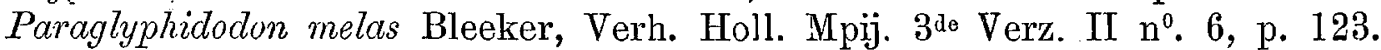

1 spec., $149 \mathrm{~mm}$ long, from Saonek, January 1910.

5. Abudefduf brownriggii (Benn.).

Chaetodon brownriggii Bennett, Fishes of Ceylon, p. 8.

Glyphidontops antjerius Bleeker, Verh. Holl. Mpij. 3 de Verz. II n ${ }^{0}$. 6, p. 134.

Glyphidontops zonatus Bleeker, ibid. p. 138.

Glyphidontops unimaculatus Bleeker, ibid. p. 140.

Glyphidontops brownriggii Günther, Fische der Südsee p. 232 (S. Syn.):

I got 16 specimens of different ages on the reef at Saonek. December 1909, which clearly show how the colour variations, on which several species have been built, are fused.

My 3 smallest specimens, 19-32 $\mathrm{mm}$ long, show two narrow bright blue stripes between the eyes, meeting in front at a sharp angle and continued backwards to the black ocellus on the dorsal. A second smaller ocellus at the axil of the dorsal (A. antjerius).

Nine specimens, 5l-68 $\mathrm{mm}$ long, belong to $A$. unimaculatus, but one of them, long $58 \mathrm{~mm}$, shows clearly the supra-ocular stripes, meeting in front, of $A$. antjerius, while another, $65 \mathrm{~mm}$ long, shows a light cross-bar on the body as in A. zonatus. Of this last named form I have two specimens, 75 and $85 \mathrm{~mm}$ long, while the two remaining ones belong to the form described by Günther l.c. sub 2 and figured Plate $12 \%$ fig. A.

The different colour varieties don't live separately on the reef, the above-mentioned unimaculatus with a crossbar was found together with two typical unimaculatus in a very small rock pool. 
6. Abudefduf spec. juv.

2 spec., 20 and $28 \mathrm{~mm}$ long, from Ambon, February 1910.

Tetradrachmum Cantor.

1. Tetradrachmum reticulatum (Rich.)

Heliases reticulatus Richardson, Rep. 15th meet. Brit. Ass. p. 254.

Tetradrachmum reticulatum Bleeker, Verh. Holl. Mpij. 3'de Verz. II $\mathrm{n}^{\mathrm{n}}$. 6, p. 145.

4 spec., from Ambon, 44-93 mm, December 1909 and February 1910.

2. Tetradrachmum aruanum (L.).

Chaetodon aruanus Linné, Systema Naturae X p. 275.

Tetradrachmum arcuatum Bleeker, Verh. Holl. Mpij. 3de Verz. II n n $^{0}$ 6, p. $14 \%$.

27 spec., 22-66 mm, from Ambon, among corals. February 1910.

3. Tetradrachmum melanurus (Blkr.).

Dascyllius melanurus Bleeker, Nat. Tijdschr. Ned. Indië, VI p. 109.

'T'etradrachmum melanurus Bleeker, Verh. Holl. Mpij. 3 de Verz. II $\mathrm{n}^{0}$. 6, p. 150.

17 spec., 15-40 mm, from Ambon, among corals. February 1910.

1. Chromis caeruleus (C. V.).

Chrom is Cuvier.

Heliases caeruleus Cuvier \& Valenciennes, Hist. Nat. Poiss. V p. $49 \%$.

Heliases lepisurus Cuvier \& Valenciennes, op. cit. V. 498.

Heliases frenatus Cuvier \& Valenciennes, op. cit. p. 498.

Heliastes lepidurus Günther, Fische der Südsee, p. 238.

Chromis lepidurus Bleeker, Verh. Holl. Mpij. $3^{\text {do }}$ Verz. II $\mathrm{n}^{0} .6$, p. 164.

Heliastes lepidurus Day, Fishes of India $4^{\circ}$. p. 389.

Chromis caeruleus Jordan and Seale, Bull. Bureau Fisheries XXV p. 290.

$5 \pm$ spec., 56-26 mm, from Ambon, among corals. February 1910.

The identity of Chr. caeruleus, lepisurus and frenatus is discussed by Bleeker 1. c.: "Tous mes individus (of Chromis lepisurus) ont 12 épines dorsales, ce qui fait douter que les Heliases frenatus et coeruleus, dont il est dit qu'ils en auraient 13, soient de la même espèce". Jordan and Seale l.c. however declare the three species doubtless identical and continue: "The type of caeruleus is said to have 13 dorsal spines, while Chromis lepisurus has 12. No other difference appears in the description". The authors don't make any further mention of this difference in the number of dorsal rays, although it seems to me an important point in the discussion, as we know that the number of dorsal spines is very constant among the Pomacentridae. Vaillant wrote in response to a request of the above-named American authors to re-examine the original types, that he agrees with their view and thinks the three species to be the same, but he too does not mention the number of dorsal rays in his letter, published by Jordan and Seale l. c. Therefore it is important that among my 54 specimens there was one exactly like the others except for the fact of having 13 dorsal spines in stead of 12 , as is the case in the 53 remaining specimens. I think that we may sifely draw the conclusion that occasionaly individuals with 13 spines occur and it seems even that the number is still more variable, as Day l. c. states that their are $11-12$ spines in this species.

Labriḍae.

Cbeilinus Lacépède.

1. Cheilinus chlorurus (Bl.).

Sparus chlorurus Bloch, Ausländische Fische V p. 24. 
Cheilinus chlorurus Bleeker, Atl. Ichth. I p. 65.

Cheilinus chlorurus Günther, Cat. Brit. Mus. IV p. 128.

Cheilinus chlorurus Day, Fishes of India $4^{\circ}$. p. 393.

1 spec., $86 \mathrm{~mm}$, from Saonek.

2. Cheilinus cercmensis Blkr.

Cheilinus ceramensis Bleeker, Nat. Tijdschr. Ned. Indië IIL p. 290. Atl. Ichth. I p. 69.

4 spec., 188-60 mm, Ambon, February 1910.

Cheilio Lacépède.

1. Cheilio inermis (Forsk.).

Labrus inermis Forskal, Descript. Animalia p. 34.

Cheilio inermis Bleeker, Atl. Ichth. I p. 82.

1 spec., $234 \mathrm{~mm}$, Saonek, January 1910.

Julis C. V.

1. Julis dorsalis Q. G.

Julis dorsalis Quoy \& Gaimard, Zool. Voy. Astrolabe III p. \%13.

Julis dorsalis Bleeker, Atl. Ichth. I p. 94.

1 spec., $133 \mathrm{~mm}$, from Sánek.

Platyglossus Klein.

1. Platyglossus notopsis (C. V.).

Julis notopsis Cuvier \& Valenciennes, Hist. Nat. Poiss. XIII p. 485.

Platyglossus notopsis Bleeker, Atl. Ichth. I p. 111.

Platyglossus notopsis Günther, Fische der Südsee, Heft VIII p. 258.

A young specimen, $18 \mathrm{~mm}$, from the reef at Saonek, December 1909.

2. Platyglossus schwarzi (Blkr.).

Julis (Halichoeres) Schwarzi Bleeker, Verh. Bat. Gen. XXIII p. \%.

Halichoeres Schwarzi Bleeker, Atl. Ichth. I p. $11 \%$.

Platyglossus Schwarzii Günther, Cat. Brit. Mus. IV p. 149.

Platyglossus (Halichoeres) Doleschalli Steindachner, Ichth. Mitth. VI, Verh. Zool. bot. Gesellsch. XIII p. 1190.

3 spec., 93—85 mm, Saonek, January 1910.

3. Platyglossus bicolor (Bl. Sch.).

Labrus bicolor Bloch, Schneider, Syst. Ichth. p. $26 \%$.

Halichoeres bicolor Bleeker, Atl. Ichth. I p. 118.

Platyglossus bicolor Günther, Cat. Brit. Mus. IV p. 145.

8 spec., 95-112 mm, Majalibit-bay, Waigeu, January 1910.

My specimens are a little higher and have the head slightly longer than those of Bleeker, while there is a black triangular spot at the base of the pectoral. The colour-pattern agrees with the description and figure given by Bleeker and as I don't find other differences, I have no doubt that my specimens belong to the above-named species.

This species was hitherto only known from the Western part of the Archipelago. 
4. Platyglossus binotopsis (Blkr.).

Julis (Halichoeres) binotopsis Bleeker, Verh. Bat. Gen. XXIII p. \%.

Halichoeres binotopsis Bleeker, Atl. Ichth. I p. 120.

Platyglossus binotopsis Günther, Cat. Brit. Mus. IV p. 153.

2 spec., 62 and $49 \mathrm{~mm}$, Saonek, reef. December 1909.

Besides these two I obtained at Saonek a very small fish, $22 \mathrm{~mm}$ long, which is uniformly green excepting a dark stripe behind the eye, a spot at the base of caudal and two spots on the dorsal, of the same size and in the same position as those in P. binotopsis, of which species I suppose this specimen to be the young. It is however possible that it belongs to the related $P$. leparensis Blkr.

5. Platyglossus kawarin (Blkr.).

Julis (Halichoeres) kawarin Bleeker, Nat. Tijdschr. Ned. Indië III p. 172.

Halichoeres kawarin Bleeker, Atl. Ichth. I p. 121.

Platyglossus kawarin Günther, Cat. Brit. Mus. IV p. 152. Fische der Südsee II p. 266.

Platyglossus kawarin Day, Fishes of India $4^{\circ}$. p. 400.

1 spec., $84 \mathrm{~mm}$, Saonek, January 1910.

The lines on the head follow another course than those figured by Bleeker and Günther, but I don't think that this is of any importance, as the two figures mentioned differ inter se too and moreover Günther says: „In seinen (Garett's, the collector) Notizen weist er ausdrücklich auf die grosse Variabilität der Körperfärbung hin". This rare species is known from the Andamans, Celebes, Timor, the Society- and Kingsmill Isles.

6. Platyglossus hyrti (Blkr.).

Julis (Halichoeres) Hyrtli Bleeker, Act. Soc. Reg. Scient. Ind. Neerl. I p. 60.

Halichoeres Hyrtli Bleeker, Atl. Ichth. I p. 121.

Platyglossus hyrtelii Günther, Cat. Brit. Mus. IV p. 149.

$\%$ spec., 99-82 mm, Majalibit-bay; Waigeu, January 1910.

¡. Platyglossus chloropterus (Bl.).

? Labrus chloropterus Bloch, Ausländ. Fische V p. 149.

Platyglossus chloropterus Günther, Cat. Brit. Mus. IV p. 144.

Halichoeres chloropterus Bleeker, Atl. Ichth. I p. 125.

A single specimen, $139 \mathrm{~mm}$, from Saonek, agreeing with Bleeker's „var. macula media dorso latissima nigra usque infra lineam lateralem descendente".

8. Platyglossus scapularis (Benn.).

Julis scapularis Bennett, Proc. Zool. Soc. 1831, p. $16 \%$

Julis caeruleovittatus Rüppell, Nene Wirbelth. Fische, p. 14.

Güntheria coeruleovittata Bleeker, Atl. Ichth. I p. $13 \%$

Platyglossus scapularis Günther, Cat. Brit. Mus. IV p. 146.

1 spec., $144 \mathrm{~mm}$, Saonek.

1 spec.; $75 \mathrm{~mm}$, Ambon, fishmarket. December 1909.

9. Platyglossus spec. juv.

19 spec., 15-35 mm, Saonek, reef. December 2\%. 1909.

Diproctacanthus Bleeker.

1. Diproctacanthus xanthurus (Blkr.).

Labroides xanthurus Bleeker, Act. Soc. Reg. Scient. Ind. Neerl. I p. 52.

Diproctacanthus xanthurus Bleeker, Atl. Ichth. I p. 156.

1 spec., $36 \mathrm{~mm}$, from Ambon, February 1910. 
This beautiful little species was hitherto only known from the two type-specimens from Menado.

My specimen quite agrees with Bleeker's description. The snout only is a little longer than the eye, and there are only 35 scales in the lateral line, whereas Bleeker states: circa 40.

Stethojulis Günther.

1. Stethojulis interrupta (Blkr.).

Julis (Halichoeres) interrupta Bleeker, Nat. Tijdschr. Ned. Ind. II p. 252.

Stethojulis interrupta Bleeker, Atl. Ichth. I p. 132.

1 spec., $92 \mathrm{~mm}$, from the fishmarket at Ambon, December \%. 1909.

\section{Carangidae.}

Chorinemus C. V.

1. Chorinemus lysan (Forsk.).

Scomber lysan Forskal, Descr. Anim. p. 54.

Chorinemus commersonianus Bleeker, Verb. Bat. Gen. XXIV Makreel. p. 44.

Chorinemus lysan Günther, Cat. Brit. Mus. II p. $4 \% 1$.

3 spec., 120-130 mm, from Beo, Majalibit-bay, Waigeu, January 1910 .

\section{Caranx Lacépède.}

1. Caranx affinis Rüpp.

Caranx affinis Rüppell, Neue Wirbelth. p. 49.

Selar Hasseltii Bleeker, Verh. Bat. Gen. XXIV Makreel. p. 53.

Caranx hasseltii Günther, Cat. Brit. Mus. II p. 234.

Caranx (Selar) affinis Klunzinger, Fische Roth. Meer. $4^{\circ}$. p. $9 \%$.

2 spec., $130 \mathrm{~mm}$, Majalibit-bay, Waigeu, January 1910.

2. Caranx macrophthalmus Rüpp.

Caranx macrophthalmus Rüppell, Atl. Fische, p. $9 \%$.

Caranx crumenophthalmus Günther, Cat. Brit. Mus. II p. 429 (partim).

Caranx (Selar) macropthalmus Klunzinger, Fische Roth. Meer. $4^{\circ}$. p. 9\%.

6 spec., 143-190 mm, Saonek, December 1909, January 1910.

2 spec., $163 \mathrm{~mm}$, from Ambon, Batu merah, March 1910.

3. Caranx boops C. V.

Caranx boops Cuvier \& Valenciennes, Hist. Nat. Poiss. IX p. 46.

Selar, boops Bleeker, Verh. Bat. Gen. XXIV Makreelacht. p. 51.

Caranx boops Günther, Cat. Brit. Mus. II p. 431.

1 spec., $70 \mathrm{~mm}$, Buton, December 3. 1909.

6 spec., $99-200 \mathrm{~mm}$, Saonek, December 1909.

4. Caranx melampygus C. V.

Caranx melampygus Cuvier \& Valenciennes, Hist. Nat. Poiss. IX p. 116.

Caranx melampygus Bleeker, Nat. Tijdschr. Ned. Indië VI p. 58.

Carcanx melampygus Günther, Cat. Brit. Mus. II p. 446.

Caranx melampygus Klunzinger, Fische Roth. Meeres $4^{\circ}$. p. 99.

Caranx melampygus Day, Fishes of India $4^{\circ}$. p. 214.

Caranx melampygus Günther, Fische der Südsee I p. 133.

1 spec., $188 \mathrm{~mm}$, from Ambon, February 1910. 
j. Caranx carangus (Bl.).

Scomber carangus Bloch, Ausländ. Fische VII p. 69.

Caranx ekala Bleeker, Verh. Bat. Gen. XXIV Makreel. p. 59.

Caranx carangus Günther, Cat. Brit. Mus. II p. 448.

1 spec, $180 \mathrm{~mm}$, from Buton, December 3. 1909.

6. Caranx hippos (L.).

Caranx hippos Linné, Syst. Naturae Ed. XII p. 494.

Caranx hippos Günther, Cat. Brit. Mus. II p. 449.

Caranx hippos Day, Fishes of India $4^{\circ}$. p. 216.

4 spec., 63-76 mm, Ambon, December 1909 and February 1910.

1 spec., $125 \mathrm{~mm}$, Majalibit-bay, Waigeu, January 1910.

3 spec., 107-111 mm, from Kairatu, W. Ceram, March 1. 1910:

1 spec., about $65 \mathrm{~mm}$, fishmarket at Macassar, March 11. 1910.

7. Caranx (Carangoides) spec.

One specimen, from Batu merah; Ambon, March 1910, too badly conserved to make out the species.

\section{Scyris C. V.}

1. Scyris ciliaris (B1.).

Zeus ciliaris Bloch, Ausländ. Fische VI p. 29.

Carangoides blepharis Bleeker, Verh. Bat. Gen. XXIV Makreel. p. $6 \%$.

Caranx ciliaris Günther, Cat. Brit. Mus. II p. 454.

Scyris ciliaris Klunzinger, Fische Roth. Meeres $4^{\circ}$. p. 101.

1 spec., $138 \mathrm{~mm}$, fishmarket at Ambon, December 1909.

2. Scyris gallus (L.).

Zeus gallus Linné, Systema Naturae Ed. X p. $26 \%$.

Carangoides galeichthys Bleeker, Verh. Bat. Gen. XXIV. Makreel. p. 68.

Caranx gallus Günther, Cat. Brit. Mus. II p. 455.

Scyris gallus Klunzinger, Fische Roth. Meeres $4^{\circ}$. p. 101.

l spec., $210 \mathrm{~mm}$, fishmarket at Ambon, December 1909.

\section{Seombridae.}

Scomber L.

1. Scomber australasicus C. V.

Scomber australasicus Cuvier \& Valenciennes, Hist. Nat. Poiss. VIII p. 49.

Scomber australasicus Günther, Cat. Brit. Mus. II p. 359.

2 specimens, 98-132 mm, from Buton. Dr. Justesen leg.

The description of this species by Cuvier \& Valenciennes and Günther is too scanty to give certainty to the identification of my specimens. I am not aware that a better description has been given later on, although this species has been recorded several times. Bleeker seems never to have seen this species, although it has been recorded by Günther from Ambon and by A. B. Meyer from North Celebes.

This species seems to be allied to S. moluccensis Blkr. My specimens however differ from lastnamed by the fact that the maxillary is shorter, its hindborder not reaching farther backwards than to below the anterior part of the eye. In consequence the number of teeth in the jaws is less, and moreover those of the upper jaw are conspicuously stronger than those of the lower jaw, whereas the reverse is the case in S. moluccensis according to Bleeker. 
There is a slight discrepance between the formules of the dorsal fin given by the authors cited above and those of my specimens, as I find only 9 spines in the first dorsal of both. The greater specimen has 5 , the smaller 6 dorsal finlets.

\section{Triehiuridae.}

\section{Trichiurus $\mathrm{L}$.}

1. Trichiurus haumela (Forsk.).

Clupea haumela Forskål, Descript. Animal. p. \%2.

Trichiurus haumela Günther, Cat. Brit. Mus. II p. 348.

Trichiurus haumela Klunzinger, Fische Roth. Meer. $4^{\circ}$. p. 120, 121.

1 spec., $295 \mathrm{~mm}$, from Kairatu, West Ceram.

\section{Pleuronectidae.}

Pseudorhombus Blkr.

1. Pseudorhombus polyspilus (Blkr.).

Rhombus polyspilus Bleeker, Nat. Tijdschr. Ned. Indië IV p. 503.

Pseudorhombus polyspilus Bleeker, Atl. Ichth. VI p. $\%$

1 spec., $139 \mathrm{~mm}$, mouth of river near Buton, island Buton, brackish water. December 3. 1909.

Platophrys Swainson.

1. Platophrys pantherinus (Rüpp.).

Rhombus pantherinus Rüppell, Atl. Reise Nördl. Afrika, Fische p. 121.

Platophrys pantherinus Bleeker, Atl. Ichth. VI p. 11.

1 spec., $14 \% \mathrm{~mm}$, Saonek, January 1910.

7 spec., 44-250 mm, Ambon, February 1910.

\section{A c hir us Lacépède.}

1. Achirus poropterus Blkr.

Achirus poropterus Bleeker, Nat. Tijdschr. Ned. Indië I p. 410.

Achirus poropterus Bleeker, Atl. Ichth. VI p. 24.

Kairatu, West-Ceram, brackish water. 11 specimens $68-19 \mathrm{~mm}$.

My specimens agree with Bleeker's descriptions in all points excepting the two following: 1) The scales on the blind side are only slightly ctenoid, in contrast to those of the other side, which are strongly so. 2) The chin is provided with very conspicuous cirri, some of them almost attaining the length of the eye, and the snout is villose on the blind side and has a tubular nasal aperture.

$$
\text { Cynoglossus Ham. Buch. }
$$

1. Cynoglossus bilineatus (Lac.).

Achirus bilineatus Lacépède, Hist. Nat. Poiss. V p. 659, 663.

Cynoglossus quadrilineatus Bleeker, Atl. Ichth. VI p. 32.

Cynoglossus bilineatus Max Weber, Siboga-Exp. Fische p. 443.

2 spec., 186 and $261 \mathrm{~mm}$, from the fishmarket at Macassar, March 1,910. 
Gobiidae.

Eleotris (Gron.) Cuvier.

1. Eleotris gyrinoides Blkr.

Eleotris gyrinoides Bleeker, Nat. Tijdschr. Ned. Indië IV p. 272.

Eleotris gyrinoides Bleeker, Versl. Akad. Amsterdam (2) XI p. 20.

Eleotris gyrinoides Günther, Fische der Südșee I p. 188.

Eleotris gyrinoides Max Weber, Nova Guinea V p. 254.

1 spec., $320 \mathrm{~mm}$, from a stream near Kajeli, Buru, December 9. 1909 (fresh water).

1 spec., $310 \mathrm{~mm}$, river Waisa, Waigeu, January 18. 1910 (fresh water).

3 spec., $69-166 \mathrm{~mm}$, from river Eme and a brook near Honitetu, W. Ceram, February 1910 (fresh water).

2. Eleotris (Oxyeleotris) aruensis Max Web.

Eleotris (Oxyeleotris) aruensis Max Weber, Abh. Senckenb. Naturf. Ges. XXXIV p. 32.

2 spec., 52-85 mm, Beo, Majalibit-bay, Waigeu, January 1910 (brackish).

3 spec., 69-78 mm, Wai Menil, Waigeu, January 5. 1910 (fresh water).

3. Eleotris (Ophiocara) porocephalus C. V.

Eleotris porocephalus Cuvier \& Valenciennes, Hist. Nat. Poiss. X1I p. $23 \%$

Ophiocara porocephalus Bleeker, Versl. Akad. Amsterdam (2) XI p. 30.

2 spec., 226-266 mm long, from a stream near Kajeli, Buru, December 9. 1909 (fresh water).

The longer of the two specimens showed, when fresh, two greenish yellow transverse bands below and behind the second dorsal. These bands are mentioned by Bleeker in the young only.

4. Eleotris (Ophiocara) aporos Blkr.

Eleotris aporos Bleeker, Nat. Tijdschr. Ned. Indië VI p. 59.

Eleotris aporos Kner, Novara-Reise, Fische p. 183.

Ophiocara aporos Bleeker, Versl. Akad. Amsterdam (2) XI p. 33.

Eleotris aporus Max Weber, Nova Guinea V, 1908 p. 252.

8 spee., 266-24 mm, Lake of Galela, Halmahera, December 13. 1909 (fresh water). nom. indig. : "Lèbo".

According to the missionary van Baarda, who procured the 6 largest specimens of the 8 mentioned above, this is the only fish known to inhabit the lake. The same is said by Kükenthal.

The specimens collected by last-named are recorded by Steindachner (Abh. Senckenb. Naturf. Gesell. XXV p. 431) as E. macrolepidota (Bl.) Gthr., which is not surprising, as Günther considers $E$. aporos Blkr. to be a synonym of this species.

5. Eleotris (Ophiocara) hoedti Blkr. [Plate II].

Eleotris Hoedti Bleeker, Nat. Tijdschr. Ned. Indië VI p. 496.

Ophiocara Hoedti Bleeker, Versl. Akad. Amsterdam (2) XI p. 35.

Eleotris Hoedti Max Weber, Nova Guinea V, 1908 p. 253.

2 spec., 215-250 mm, River near Kajeli, Buru, December 9. 1909 (fresh water).

1 spec., $125 \mathrm{~mm}$, river Waiha, Waigeu, December 20. 1909 (fresh water).

2 spec., 205-220 mm, brook at Mumes, Waigeu, December 29-30. 1909 (fresh water).

4 spec., 66-136 mm, river Waisa, Waigeu, January 18. 1910 (fresh water).

2 spec., $106-120 \mathrm{~mm}$, Ambon, February 1910.

The figures 6 and $y$ on Plate II represent two male specimens, caught together in the river near Kajeli; Buru. They clearly show the variety of coloration in this species. Most specimens are much duller than those figured here aud miss the purple spots on the body 
which makes me suppose that my Buru-specimens are in nuptial dress. Although both are males, there is a marked difference in the colouring of the vertical fins, the caudal being spotted in the larger specimen, which has moreover an orange-red anal, freckled with yellow, and a black soft dorsal with yellow markings, while on the other hand the caudal of the smaller specimen is unspotted, the anal is blackish, with yellowish rays and two red bars, with a yellow one between them, at the base of the fin. While red is wanting in the second dorsal of the larger specimen, there is a row of bright red spots between the bases of the rays of that fin in the smaller specimen.

6. Eleotris (Culius) fuscus (Bl. Schn.).

Poecilia fusca Bloch, Schneider, Syst. Ichth. p. 453.

Culius fuscus Bleeker, Versl. Akad. Amsterdam (2) XI p. 40.

29 spec, 26-86 mm, river Waihă, Waigeu, fresh water above rapids, December 20. 1909.

3 spec, 81-95 mm, brook at Mumes, Waigeu, fresh water, December 29. 30. 1909:

8 spec., 37-84 mm, river Rabiai, Waigeu, fresh water, December 31. 1909.

2 spec., $7 \%-105 \mathrm{~mm}$, small branch of river Bajon, Waigeu, fresh water, January 9. 1910.

7 spec., $53-87 \mathrm{~mm}$, river Waisa, Waigeu, fresh water, January 18. 1910.

2 spec., 100-1 $24 \mathrm{~mm}$, Ambon, February 1910.

1 spec., $57 \mathrm{~mm}$, river Batu merah, Ambon, March 1910.

\%. Eleotris (Culius) melanosoma Blkr.

Eleotris melanosoma Bleeker, Nat. Tijdschr. Ned. Indië III p. \%05.

Culius melanosoma Bleeker, Versl. Akad. Amsterdam (2) XI p. 43.

1 spec., $45 \mathrm{~mm}$, from river Waihă, Waigeu, fresh water above rapids. December 20. 1909.

A young specimen, $23 \mathrm{~mm}$ long, from the river Waiu waigé, Waigeu, possibly belongs to this species.

8. Eleotris (Belobranchus) belobrancha C. V.

Eleotris belobrancha Cuvier \& Valenciennes, Hist. Nat. Poiss. XII p. 243.

Belobranchus Quoyi Bleeker, Versl. Akad. Amsterdam (2) XI p. 53.

1 spec., $7 \% \mathrm{~mm}$, River Riuapa, West Ceram, February 22. 1910 (fresh water).

3 spec., 38-50 mm, upper course of the river Tuba, West Ceram, February 27. 1910 (fresh water).

This species seems to be confined to the Malay Archipelago. Recently (Ann. Mag. Nat. Hist. (8) I p. 153) it has been recorded from New Guinea by Tate Regan.

9. Eleotris (Butis) butis (Ham. Buch.),

Cheilodipterus butis Hamilton Buchanan, Fish. Gang. p. $5 \%$

Butis butis Bleeker, Versl. Akad. Amsterdam (2) XI p. 62.

1 spec., $102 \mathrm{~mm}$, river Waiu waigé, Waigen, fresh water but under tidal influence. December 24. 1900.

My specimen has only squamulae at the base of a few scales of the trunk, which points to E. amboinensis. The dentition however is typical of butis, as described by Bleeker l.c.

10. Eleotris (Butis) amboinensis Blkr.

Eleotris amboinensis Bleeker, Nat. Tijdschr. Ned. Indië V p. 343.

Butis amboinensis Bleeker, Versl. Akad. Amsterdam (2) XI p. 66.

Eleotris amboinensis Max Weber, Nova Guinea V p. 253.

2 spec., 45-47 mm, Kajeli, Buru, December 4.1909 (fresh water).

6 spec., 22--84 mm, Kairatu, West Ceram, February 16. 1910 (brackish water). 


\section{Rhiacichthys Boulenger.}

1. Rhiacichthys aspro (C. V.).

Platyptera aspro Cuvier \& Valenciennes, Hist. Nat. Poiss. XII p. 321.

Platyptera aspro Bleeker, Nat. Tijdschr. Ned. Indië IX p. 310.

1 spec., $157 \mathrm{~mm}$ long, from a streamlet running into the river Eme, West Ceram.

\section{Gobius L.}

1. Gobius echinocephalus Rüpp.

Gobius echinocephalus Rüppell, Atl. Reise nach Afrika, Fische p. 136.

Gobius amiciensis Cuvier \& Valenciennes, Hist. Nat. Poiss. XII p. 135.

Gobius xanthosoma Bleeker, Nat. Tijdschr. Ned. Indië III p. 703.

Gobius melanosoma Bleeker, ibid.

Gobius echinocephalus Max Weber, Siboga-Exp. Fische p. $45 \%$

15 spec., 19-35 mm, Ambon, between corals. February 1910.

2. Gobius variabilis Steind.

Gobius variabilis Steindachner, Abh. Senckenb. Naturf. Gesellsch. XXV p. 430.

Gobius variabilis Max Weber, Siboga-Exp. Fische p. 458.

8 spec., $28-47 \mathrm{~mm}$, from the reef at Saonek, December 1909.

3 spec., 69-72 mm, Batu merah, Ambon, March 1910.

3. Gobius javanicus Blkr.

Gobius javanicus Bleeker, Nat. Tijdschr. Ned. Indië XI p. 88.

2 spec., $46-55 \mathrm{~mm}$, Upper course of river 'Tuba, West Ceram: February 2\%. 1910 (fresh water).

My specimens closely agree with the description given by Bleeker. I find however one ray less in the second dorsal, while the body is longitudinally banded with brown. Two bands running parallel to eachother along the middle of the sides are darker than the other ones. These bands are united at distances by dark blotches, formed by the dark margins of two or three consecutive scales of the longitudinal row, between which the bands run.

\section{Gobius oyensi n. sp.}

D. VI. I. 6. A. I. 6. P. 1\% L. 1. 26. 1.tr. 7 (between anal and $2^{\text {nd }}$ dorsal).

Moderately compressed. Profile slightly sloping down from the beginning of the first dorsal, where the body has its greatest height, to the eyes and from those running downwards to the snout, the tip of which is much below the level of the lower border of the eye. Height 4 in length without caudal. Head about $31 / 3$ in length without caudal, its width $13 / 5$ in its length, which is more than its height. Eyes more than 4 times in length of head, about equal to snout and about 2 times in the postorbital part of head. They are placed high up in the head, looking upwards and sidewards and only

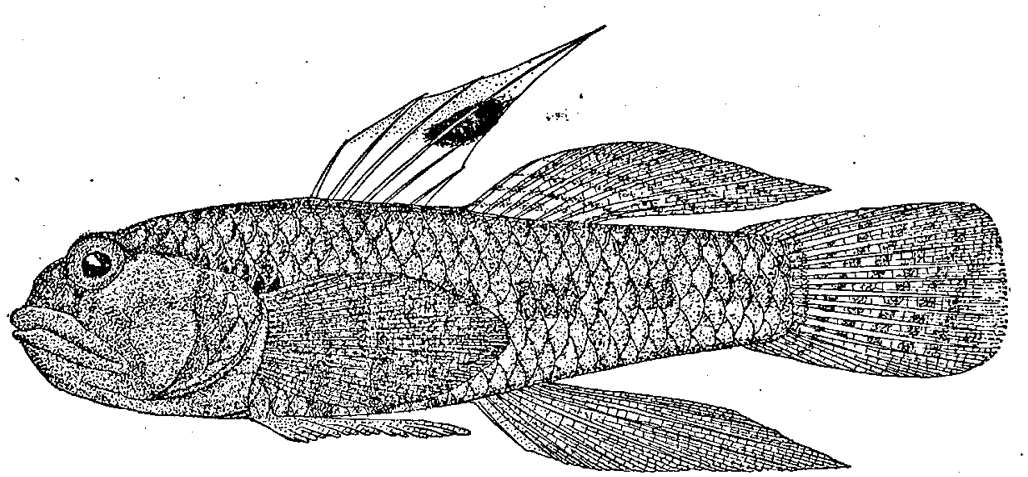

Fig. 4. Gobius oyensi n. sp. about $1 / 2$ of their diameter apart. Posterior nostril tubular, just in front of eye; anterior nostril below and a little in front of posterior nostril and provided with a valve. Gape very oblique, reaching to below hindborder of eye; lips thick and swollen; jaws subequal. Swollen muciferous 
canals form parallel rows on the chin, between the two mandibles. These muciferous canals are also visible on the snout, above the posterior nostril and faintly on the swollen cheeks. Gillmembranes united with and separated from eachother by the isthmus. The head is destitute of scales, excepting some large scales on the operculum in about 2 rows, and the upper part of the head behind the eyes, which is covered with scales and conspicuously separated from the naked cheeks by a deep furrow, running on each side from the hindborder of the eye to the upperborder of the operculum. There are about 8 rows of scales in front of the dorsal. These scales, as also those on the opercle and those of the abdomen, are cycloid, the rest is ctenoid, all are of about the same size. $4^{\text {th }}$ ray of first dorsal much longer than the others and much longer than length of head. Second dorsal higher behind than in front, its longest ray not much shorter than head. Anal pointed, the middle rays being the longest and about equal to longest ray of first dorsal. Caudal truncated, its length a little more than head without snout. Pectorals acutely rounded, about as long as the head and a little longer than ventrals. 4-5 strong, curved canini on each side in the fore part of the upper jaw, forming one continuous band of teeth in the front of the mouth. Behind those and along the sides of the upper jaw small teeth, without canini or caninoids, behind the canini in several rows. Teeth in the mandible small and pointed, forming a broad band at the symphysis, but only a stripe (of one row?) along the sides. On both sides of the mandible laterally 2 canini, which are not so strong as those of the upper jaw. Tongue not notched. Colour yellowish brown, with fine brown blotches along the sides and indications of an alternating row above those. Three brown transversal bands on the belly, hidden by the ventral-disk; the hindermost running through the anus. Two scales behind the operculum dark brown as well as a stripe running from the eye to the middle of the upper lip. Second dorsal and caudal banded with brown, first dorsal with an indication of a black band through its upper part and a black spot between the third, fourth, and fifth ray.

1 spec., $26 \mathrm{~mm}$, from the river near Kajeli, Buru, December 9. 1909.

1 spec., $65 \mathrm{~mm}$, from the upper course of the river Tubah, W. Ceram, February 2\%. 1910.

The diagnosis given above is based on the larger specimen of the two, as the pecularities of the dentition were not to be made out in the smaller specimen, which moreover only shows vestiges of the colour pattern. I have examined another specimen, of $35 \mathrm{~mm}$ length, from the island of Babber, taken in the Jer (river) Toilela, near Tepa, at $500 \mathrm{M}$. of the mouth by Mr. F. A. H. Weckherlin de Marez Oyens, to whom I dedicate this species. This specimen, which is mentioned as Gobius spec. by Max Weber and myself ${ }^{1}$ ) in our list of fishes from Babber, is similar to the type in every respect, but misses the bands on the belly.

This species is characterised by the long maxillaries and the small number of rays in the dorsal and anal fin.

5. Gobius (Gnatholepis) knighti (Jord. \& Everm.).

Gnatholepis knighti Jordan \& Evermann, Bull. U. S. Fish. Comm. XXII p. 204.

Gnatholepis knighti Jordan \& Evermann, Bull. U. S. Fish. Comm. XXIII p. $48 \%$.

Gnatholepis knighti Jordan \& Seale, Bull. Bur. Fish. XXV p. 395.

3 spec., 21-28 mm, from the reef at Saonek, December 1909.

This species is allied to $G$. cauerensis (= ophthalmotaenia) Blkr. and G.capistratus Peters. It differs from the former by having no free silk-like rays in the pectoral, at least this is the case in my specimens. Nothing is said about this point in the description of this fish, but Jordan \& Evermann mention under the characteristics of the genus Gnatholepis: „pectoral with silky rays". In the accompanying plate however, the pectoral rays are represented as united. The tongue is notched, as has already been observed by Jordan and Seale.

1) Max Weber \& L. F. de Beaufort, Over de Zoetwatervisschen van Timor en Babber, Verslag Akad. Amsterdam. 1912. p. 133. 
6. Gobius ornatus Rüpp.

Gobius ornatus Rüppell, Atl. Reise Afrika p. 135.

Gobius interstictus Richardson, Voy. Erebus \& Terror, Fishes p. 3.

Gobius periopthalmoides Bleeker, Nat. Tijdschr. Ned. Ind. I p. 249.

Gobius ornatus Günther, Cat. Brit. Mus. III p. 21. Fische der Südsee p. 172.

Gobius ornatus Day, Fishes of India $4^{\circ}$. p. 294.

27 spec., 22- $79 \mathrm{~mm}$, Saonek, reef, December 1909.

1 spec., $68 \mathrm{~mm}$, Sorong, New Guinea, January 1910.

4 spec., 48-5\% mm, Batu merah, Ambon, March 1910.

One of the specimens of Ambon has 7 rays instead of 6 in the first dorsal.

7. Gobius semidoliatus C. V.

Gobius semidoliatus Cuvier \& Valenciennes, Hist. Nat. Poiss. XII p. 67.

Gobius semidoliatus Klunzinger, Synopsis Fische Roth. Meer. p. 475.

Gobius semiifasciatus Kner, Sitzb. Akad. Wien LVIII p. 326.

Gobius semidoliatus Day, Fishes of India $4^{\circ}$. p. 295.

Zonogobius semidoliatus Jordan \& Seale, Bull. Bur. Fisher. XXV p. $39 \%$.

Gobius semidoliatus Max Weber, Siboga-Exp. Fische p. 462.

One specimen, $23 \mathrm{~mm}$ long, from the reef at Saonek, December 1909.

8. Gobius ophthalmicus M. Web.

Gobius ophthalmicus Max Weber, Notes Leyden Mus. XXXI p. 150. Siboga-Exp. Fische, p. 463.

12 spec., 12-38 mm, reef at Saonek, December 1909.

My specimens quite agree with those described by Prof. Weber. In my largest specimen however I find a strong curved canine tooth in the lower jaw.

9. Gobius melanocephalus Blkr.

Gobius melanocephalus Bleeker, Verh. Bat. Gen. XXII p. 33.

Gobius personatus Bleeker, t. c. p. 34 .

Gobius grammepomus Bleeker, t c. p. 34.

Gobius grammepomus Bleeker, Nat. Tijdschr. Ned. Indië IX p. 200.

Gobius litturatus Steindachner, Sitzb. Akad. Wien XLII p. 289.

Gobius grammepomus Günther, Cat. Brit. Mus. III p. 64, p. 554.

Gobius personatus Day, Fishes of India $4^{\circ}$. p. 292.

Gobius melanocephalus Vinciguerra, Ann. Mus. Civ. Genova (2) IX p. 173.

Gobius melanocephalus Max Weber, Siboga-Exp. Fische, p. 465.

1 spec., $118 \mathrm{~mm}$, upper course of river Rabiai, Waigeu, fresh water, December 31. 1909.

1 spec., $105 \mathrm{~mm}$, upper course of river Riuapa, West Ceram, fresh water, February 22. 1910.

1 spec., $109 \mathrm{~mm}$, upper course of river Tuba, West Ceram, fresh water, February 21. 1910.

There are not only scales on the operculum, in the manner described by Max Weber l. c., but there are several longitudinal rows of scales on the cheeks too. In one of my specimens these rows are very clearly visible and 6 in number, leaving the ventral part of the cheeks naked. Bleeker and the later authors doubtlessly overlooked these scales.

Prof. Max Weber pointed out to me a marked sexual difference in this species. The head of the male is much darker, more or less leaden grey above and below, as also the pectorals and the ventrals. In the female on the contrary, there exists a black spot on the hinder half of the first dorsal, which is wanting in the male.

10. Gobius puntang $\cdot \mathrm{Blkr}$.

Gobius puntang Bleeker, Nat. Tijdschr. Ned. Indië II p. 486.

Gobius puntangoides Bleeker, Nat. Tijdschr. Ned. Indië V p. 242. 
Gobius puntangoides Günther, Cat. Brit. Mus. III p. 19.

Gobius puntangoides Günther, Fische der Südsee III p. $1 \% 1$.

Exyrias puntangoides Jordan \& Seale, Bull. Bur. Fish. XXV p. 405.

9 spec., $104-\mathrm{I} 44 \mathrm{~mm}$, Majalibit-bay, Waigeu, January 1910 (strongly brackish).

2 spec., $125-165 \mathrm{~mm}$, Ambon; Batü-merah, February 1910.

11. Gobius (Glossogobius) giuris Ham. Buch.

Gobius giuris Hamilton Buchanan, Fishes Ganges p. 51.

Gobius giuris Max Weber, Siboga-Exp. Fische p. 468.

1 spec., $288 \mathrm{~mm}$, from a stream near Kajeli, Buru, December 9. 1909.

12. Gobius (Glossogobius) celebius C. V.

Gobius celebius Cuvier \& Valenciennes, Hist. Nat. Poiss. XII p. 56.

Gobius celebius Max Weber, Siboga-Exp. Fische p. 468.

1 spec., $140 \mathrm{~mm}$, Buli, Halmahera (Mission. Maan. leg.).

13. Gobius reticularis Max Web.

Gobius reticularis Max Weber, Abh. Senckenb. Naturf. Ges. XXXIV p. 38.

1 spec., $14 \mathrm{~mm}$, river Rabiai, Waigeu, December 31. 1909.

21 spec., $16-22 \mathrm{~mm}$, river Waihă, Waigen, December 20.1910 (fresh water, above rapids).

1 spec., $15 \mathrm{~mm}$, (bad condition) upper course of river. Tuba, W. Ceram, February $2 \%$. 1910 (fresh water).

14. Gobius rouxi M. Web.

Gobius rouxi Max Weber, Abh. Senckenb. Naturf. Ges. XXXIV p. 40.

1 spec., $16 \mathrm{~mm}$ long, from the mouth of the river Riuapa, Kairatu, W. Ceram, February 16. 1910 (brackish water).

15. Gobius (Rhinogobius) scapulopunctatus de Bfrt.

Gobius (Rhinogobius) scapulopunctatus de Beaufort, Zool. Anz. XXXIX, p. 137.

D. VI. 8(9). A. 8. 1.1. $\pm 2 \%$. 1.tr. 8 .

Body compressed, with the head slightly depressed, the height of the head being slightly less than its breath. The height of the body is $1 / 5$ of the total length $(1 / 4$ of the length

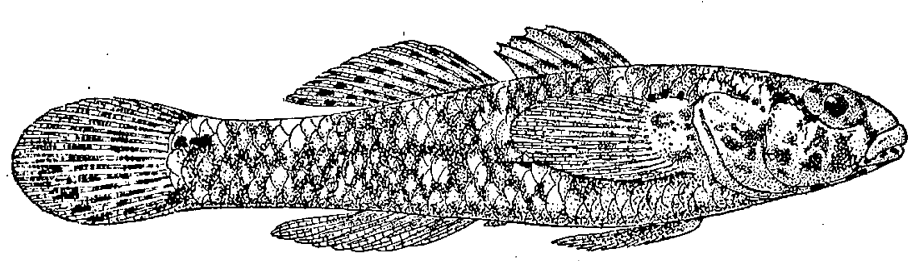

Fig. 5. Gobius (Rhinogobius) scapulopunctatus de Bfrt. without caudal). The length of the head is $1 / 4$ of the total length $(3 / 10$ of the length without caudal). The dorsal profile gently slopes from the first dorsal to the eye, from here it bends rather abruptly down to the snout. The eyes are very close together, prominent above the dorsal profile and situated in the first half of the head. Their diameter is $21 / 2-3$ times the length of the head. The snout is rather obtuse and shorter than the eye. Anterior nostrils tubular. Sides of head and opercles naked. Crown of head and neck covered by rather large scales, partly inbedded in the skin and not easily visible. A pore between the eyes and behind each eye as well as on the hinder margin of the praeoperculum. Rictus somewhat oblique. Jaws almost equal. Maxilla reaching under the front border of the eye. Lips thick. Tongue truncated, with rounded edges and the frontmargin slightly curved inwards. Outer row of teeth in both jaws enlarged, lancet-like. Scales ctenoid, those on the fore part of the body slightly smaller than the rest. First dorsal lower than the body in the female, in the male the middle rays are prolonged and exceed the height of the body. Second dorsal beginning above the vent, lower than the body. Anal beginning behind the second dorsal, lower than the body and with the hindermost rays the longest. 
Pectorals as long as the head, none of the rays free and silk-like. Ventrals short, not reaching the vent, the rays prolonged beyond the membrane, giving the border of the fin a festooned appearance. Caudal rounded, $1 / 5$ of the total length.

Colour in spirits whitish, with 5 saddle-like brown bands on the back. The first on the neck, the second under the first dorsal, the third and fourth under the second dorsal and the fifth on the tail. Ventrally they reach to the middle of the body, where they are partly confluent with a longitudinal row of somewhat darker brown blotches. A dark brown elongate patch under the eye and an indistinct stripe running forward from the eye to the mouth. Brown patches on the sides and on the under surface of the head. Three or four small black spots above the origin of the pectoral. A black spot on the dorsal side and in the middle of tail at base of caudal. The male has some scattered black spots along the sides of the body and along the back, similar to those above the pectoral. Two indistinct black bands on first dorsal. Rays of second dorsal and anal with black spots, forming dark bands on the fins. Pectorals, ventrals and anal dusky, darker in the male.

3 spec. (2 むす, one $\sigma^{7}$ ) $20-24 \mathrm{~mm}$, from the reef at Saonek. December 1909.

This species is allied to Ctenogobius hadropterus Jord. \& Snyd. from Japan, from which it differs by having a shorter snout, a larger eye (age differences?) and by having the second dorsal placed more in advance, besides other small differences. It may easily be distinguished by the three or four black spots above the pectoral.

16. Gobius (Cryptocentrus) stigmatophorus de Bfrt.

Gobius (Cryptocentrus) stigmatophorus de Beaufort, Zool. Ànz. XXXIX p. 136.

D. VI. $12(13)$. A. $13(14)$. P. 16. l.l. \pm 80 , l.tr. \pm 20 .

Body elongate, laterally compressed. Its height is contained 6 times in the total length, 5 times in the length without caudal. The length of the head is contained 4 times in the total length, more than 3 .times in the length without $C$. The height of the head is a little more than the half of its length. The eyes are very close together, situated in the first half of the head and their diameter is contained $32 / 3$ times in the length of the latter. The obtuse snout is shorter than the eye. The rictus is oblique. The maxilla reaches not quite as far back as a vertical from the centre of eye. There are 8 canini on each side in the upper jaw and 5 or 6 on each side in the lower jaw. The outer ones of those in the mandible are stronger than the others and curved backwards. The scales are ctenoid, especially so on the sides of the body and on the tail, where they are larger than on the fore part of the body. The head is naked, the scales beginning just in front of the dorsal fin. The 3rd ray of the $1^{\text {st }}$ dorsal is the longest and about $4 / 5$ of the height of the body. The second dorsal is close to the first one. Its length is not quite twice that of the first dorsal and a little more than that of the anal. Its height is less than that of the first dorsal. The pectorals are rather pointed, their length is equal to the distance from the posterior margin of the operculum to the middle of the eye; none of the rays free. The ventrals are slightly shorter than the pectorals and do not reach the vent. The caudal is obtusely pointed and $1 / 5$ of the total length: Colour in spirits greyish brown, with about 14 vertical narrow light bands on the body. Cheeks and operculum spotted with light blue ocelli, surrounded by deeper blue. Most of the scales of the body have a blue vertical stripe. Besides these light spots and stripes there are black spots on the sides of the head and on the sides of the body. Some larger spots behind the eye and above the hinder margin of the operculum, where they are confluent and form a conspicuous dark patch. A black band crosses the basal portion of the first dorsal, 3 rows of black spots on the second dorsal. Anal with a submarginal dusky band and a dark spot at the base between each ray. Caudal crossed by about 5 dark bands, formed by spots between the rays. Pectorals dusky at base, ventrals pigmented with dusky.

One specimen, $31 \mathrm{~mm}$ long, from the reef of Saonek, December 1909.

This species is closely allied to Gobius arabicus L., which has a similar pattern of coloration. When we compare the measurements given by Steindachner (Denkschr. Akad. Wien, 
LXXI, p. 14i) for a juvenile $G$. arabicus with those of $G$. stigmatophorus, we find that in the latter the head is longer and the eye larger. In its mode of coloration this species has some resemblance with Cryptocentrus octofasciatus Tate Regan.

$$
\text { Callogobius Bleeker. }
$$

1. Callogobius hasseltii (Blkr.).

Eleotris Hasseltii Bleeker, Nat. Tijdschr. Ned. Indië I p. 253.

Eleotris Hasseltii Bleeker, Nat. Tijdschr. Ned. Indië XI p. 412.

Callogobius hasseltii Max Weber, Siboga-Exp. Fische p. 480.

4 spec., $19-51 \mathrm{~mm}$, from the reef at Saonek, December 1909.

\section{G obi od on Bleeker.}

1. Gobiodon quinquestrigatus (C. V.).

Gobius quinquestrigatus Cuvier \& Valenciennes, Hist. Nat. Poiss. XII p. 134.

Gobiodon quinquestrigatus Bleeker, Archiv. Neerl. X p. $11 \%$.

3 spec., 26-38 mm, Ambon, among corals, February 1910.

2. Gobiodon hypselopterus Blkr.

Gobiodon hypselopterus Bleeker, Archiv. Neérl. X p. 120.

1 spec., $42 \mathrm{~mm}$, from the coral-reefs at Ambon, February 1910.

Schismatogobius de Bfrt.

(Zool. Anz. XXXIX p. 139).

Body elongate, naked. Teeth fixed, long, needle-like, curved backwards at the end, widely set in several rows in both jaws. Maxilla produced far behind the eye. Vertical fins well

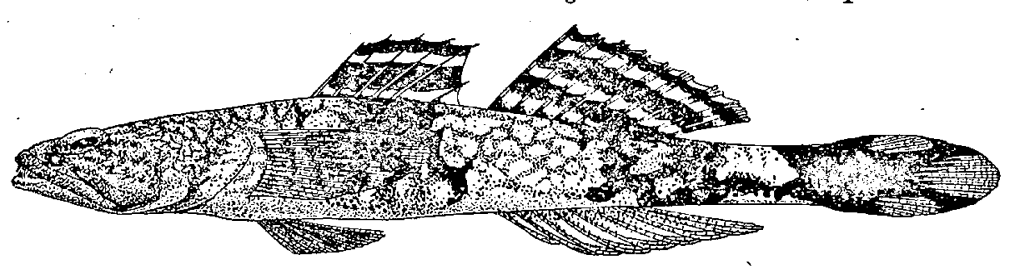

Jï.. 6. Schismatogobius bruynisi de Bfrt. developed, first dorsal with six spines. Ventrals united, forming a well developed disk.

Gobiosoma longipinne Steind. from the Gulf of California may possibly find a place in this genus, besides the type Sch. bruynisi, described below.

Jordan \& Evermann (Fishes of N. America) placed Steindachner's species in the genus Evermannia, making (p. 2256) however the remark, that it may be the type of a distinct genus. It agrees with Sch. bruynisi, in the fact of having a naked body combined with a produced maxilla, these features being the chief characteristics of the new genus. It differs however in having a much longer second dorsal and anal, with $16-17$ rays, while my species has only 9 rays in those fins. The teeth of $G$. longipinne are described by Steindachner as follows: "die beiden Kiefer... tragen seitlich zwei, vorn 3 Reihen kleiner spitzer Zähne". According to this description "the teeth seem to be much smaller than in Sch. bruynisi and probably they are not curved backwards, as Steindachner does not mention anything of that kind.

1. Schismatogobius bruynisi de Bfrt. (Plate II fig. 2).

Schismatogobius bruynisi de Beaufort, Zool. Anz. XXXIX p. 139.

D. VI. 9. A. 9.

Body naked, elongate, compressed, head depressed, the neck and the crown of the head flattened, giving to the latter a snake-like appearance. The height of the body is contained more than 7 , times in the total length, 6 times, in the length without caudal. Profile sloping gradually from the first dorsal to the point of the snout. The latter is pointed, slightly 
shorter than the eye. Eyes situated much nearer to the end of the snout than to the hinder margin of the operculum, close together. Their longest diameter is contained 4 times in the length of the head. The latter is contained a little more than 4 times in the total length, $3 \%$ times in the length without caudal. Rictus oblique. Praemaxilla protractile. Maxilla very long, extended backwards far behind the eye, longer than the postorbital part of the head. Lips moderately thick. Teeth fixed, long, needle-like, curved backwards at tip, widely set, in the upper jaw in three rows in front. In the lower jaw the teeth in the back-row are strongly inclined backwards. The tooth-row in the upper jaw much longer than that of the lower jaw, the latter row extending half way the length of the rictus. Isthmus very broad. The first dorsal is lower than the body. The distance between the fitth and sixth ray is much more than that between the other ones. The second dorsal is in front as high as the body, and diminishes in height backwards. The anal begins scarcely behind the second dorsal and is less high than the body. The pectorals are pointed, as long as the head without snout. The ventrals are united and are shorter than the pectorals. Their length is slightly more than that of the postorbital part of the head. Caudal rather pointed, equalling the ventrals in length.

Colour yellow, reticulated all over with brown. Under the first and the second dorsal these reticulations are broader, deep black and partly confluent, forming two transversal irregular dark bands on the body. Distal end of tail black, as well as the caudal fin, which has three yellow spots, one terminal and the two others dorsally and ventrally. The black of the tail is united by a fine longitudinal black band with the black under the second dorsal. The two dorsal fins are deep black, the first one crossed by two, the second by three longitudinal yellow bands. Anal yellow, blackish along its base. Pectorals with an irregular black band. Ventrals with a subterminal black bar.

One specimen, $39 \mathrm{~mm}$, from the river Eme, Honitetu, West Ceram (fresh water), February 24. 1910.

Named in honour of Lt. J. Bruynis, commanding officer of the military post at Honitetn, who helped us in every possible way.

Microsicydium Bleeker.

1. Microsicydium gymnauchen (Blkr.).

Sicyclium gymnauchen Bleeker, Act. Soc. Sc. Ind. neerl. III p. \l.

- Microsicydium gymnauchen Bleeker, Versl. Akad. Amsterdam, $2^{\text {de }}$ reeks IX p. 15. Microsicydium gymnauchen Max Weber, Abh. Senckenb. Naturf. Gesellsch. Bd. XXXIV p. 46.

1 spec., 39 mm, river Eme, West Ceram, February 20. 1910 (fresh water).

This specimen is longer than either the 300 specimens examined by Bleeker or those mentioned by Max Weber. I cannot find the canines in the mandible, described by the latter author. The colouring of my specimen is somewhat different to those of Bleeker. There are no traces of transversal bands, but there exists a black longitudinal line, running from the upper lip backwards under the eye, over the base of the pectoral fin and along the sides to the caudal fin, on the base of which the line ends in a dark spot.

Stiphodon Max Weber.

I. Stiphodon elegans (Steind.) (Plate II fig. 4 \& 5).

Sicydium elegans Steindachner, Sitzungsber. Akad. Wien p. 152.

Sicydium elegans Ogilvie Grant, Pr. Zool. Soc. 1884 p. 162.

Stiphodon semoni Max Weber, Semon. Forschungsr. V p. $2 \%$.

Microsicydium elegans Jordan \& Seale, Bull. Bur. Fish. XXV p. 411.

Stiphodon Semoni Max Weber, Nova-Guinea V p. 264.

1 spec., $19 \mathrm{~mm}$, Batjan, December 1l. 1909. 
37 spec., 29-43 mm, river Eme, West-Ceram (fresh water), February 1910.

l. spec., $34 \mathrm{~mm}$, river Riuapa, West-Ceram (fresh water), February 22. 1910.

14 spec., 25-30 mm, river Tuba, West-Ceram (fresh water), February 2\%. 1910.

Max Weber established the genus Stiphodon for a small gobioid from Ambon, allied to Sicycium in its dentition, but differing by having a free ventral disk, not adherent to the belly as in the latter genus. Previously however Steindachner had described the same fish as Sicydium elegans. It is incomprehensible why Steindachner ranged this fish - without any remark - in the genus Sicydium, as he states in his diagnosis: "Ventrale frei". In his revision of the genus Sicydium Ogilvie Grant placed S. elegans among the other members of the genus. As his description is a copy of that of Steindachner, I suppose that he did not see specimens. Jordan and Seale, who neither saw specimens, mention the species under the name of Microsicydium elegans, saying of the genus Microsicydium of Bleeker that "it may be provisionally distinguished from Sicyopterus by the large scales". Bleeker however has given a complete diagnosis of Microsicydium (Verh. en Med. Kon. Akad. Amsterdam $2^{\text {de }}$ reeks IX p..15), which genus has nothing to do with the species under discussion. The scales are not large as supposed by Jordan and Seale, but the small number of scales in the linea lateralis is due to the fact that the first part of the body is naked.

Max Weber has already drawn attention to the remarkable sexual dimorpbismus in this species. While the females are longitudinally banded, the males are of a dark brown or blackish colour in spirits, lighter on the belly. In life however there is a splendid, shining blue line along the side, which disappears almost immediately after death. Some of my larger female specimens are strongly shaded with carmin along the sides (Plate II fig. 5). Two other much smaller specimens are bright carmin all over, the vertical fins included. Along the back there are traces of a brown band. The head is blue (with exception of the occiput) (Plate II fig. 4). I can't find any. differences - besides the colour - between these specimens and the other ones. A bluish black head with a light brown occiput may be seen in several other male specimens so that it seems to me not improbable that these are specimens of the same species in nuptial dress. It is not easy to make out the sex of the two small specimens without destroying them. The genital papilla seems to be only slightly different in the two sexes of this species, being truncated and slightly emarginated or bicorned in the female and obtusely pointed in the male. If this holds good, one of the two specimens in nuptial dress would be a female, the other one, which has the rays of the first dorsal elongated, a male. If this were true, the sexes would be much more alike in the nuptial dress than they are in the ordinary dress. At all events the females have a tendency to become carmin in the fraying period, as is shown by one of the above-mentioned females with carmin shades on the sides, which had the ovarium filled by almost ripe eggs. Max Weber described a male specimen (with elongated first dorsal) with two yellowish cross bars, one in front and the other behind the second dorsal, the body being brown in spirits. Great range of variation, not only in colour but also in the pattern, seems to be a characteristic of this species.

Stiphodon elegans is known from the Society-islands (Steindachner), New Guinea, Ambon, (Max. Weber) Batjan and Ceram. Moreover there are specimens in the museum at Amsterdam from Java and Nias. It seems to have a wide distribution but being rather rare at the same time. I have compared one of the typical Stiphodon semoni Max Weber with Steindachner's description of Sicydium elegans and I cannot find any difference.

I found this species at Ceram and Batjan in clear mountain streams.

Gen. Sicy opus Gill.

When Bleeker described (Nat. Tijd. Ned. Ind. XII p. 296) Sicydium zosterophorum and balinense, he remarked that it was only with hesitation that he brought these two species under the genus Sicydium, as they had no labial teeth, and as the teeth in the upper jaw were not bristle-like but formed in the same way as in the mandible. In a footnote on p. 262 
of the Proc. Acad. Philadelphia 1863, Gill created for these species (apparently without having seen them), the genus Sicyopus. We can scarcely say that he gave a diagnosis of the genus, as may be seen from the above-quoted footnote, which runs as follows: "The Sicydiinae are represented by four genera Sicydium (old world), Sicyopterus (new world), Sicyopus. (without labial teeth, \&c., and embracing Sicydium zosterophorum Blkr., and S. balinease Blkr.), and Sicyogaster Gill.". In his "Esquisse d'un système naturel des gobioides", (Arch. Neerl. IX), Bleeker adopted the genus, but did not place it among the Sicydiini but among the Latrunculini. The short diagnosis given there was enlarged in the "Révision des Sicydiini et Latrunculini de l'Insulinde" (Versl. Akad. Amsterdam, 2do reeks IX). Bleeker removed the genus from the Sicycliini because he restricted the Sicydiini to forms with labial teeth. Besides the two species of Bleeker, three specimens in all, it seems that no specimen of the genus was ever found. Among my material, collected in the mountain streams of West Ceram, are two well-preserved specimens of $S$. zosterophorum, besides a new species, with a considerable greater number of scales (about 55) in the lateral line. As Bleeker mentions in the diagnosis of the genus: "Squamae... 32 circ. in serie longitudinali", it will be necessary to change the diagnosis in this respect.

This new diagnosis may run as follows: Body elongate, habitus Sicydium-like. Head naked, body scaled, with ctenoid scales, 32-55 in the 1. 1. No labial teeth. Teeth in both jaws in a single row, pointed and more or less apart. Lips thick, eleft of the mouth horizontal. Isthmus broad. Ventrals round, formed as in Sicydium but free from the belly. D. VI. 10-11. A. $10-11$.

The genus has certain affinities with Stiphodon, specially in the shape of the ventrals, but it differs from this genus by the absence of labial teeth.

1. Sicyopus zosterophorum Blkr. (Plate II fig. 3).

Sicydium zosterophorum Bleeker, Nat. Tijdschr. Ned. Indië XII p. 296.

Sicyopus zosterophorum Bleeker, Versl. Akad. Amsterdam 2do reeks, IX p. 28\%:

2 spec., 38-45 mm, river Eme, West-Ceram, February 20. 1910 (fresh water).

The two specimens mentioned above quite agree with the description of the single specimen hitherto known and described by Bleeker. The colour of the hind part of the body is brick-red in life, as well as the second dorsal, the anal and the upper margin of the first dorsal. The smaller of the two specimens has a large blue spot on the first dorsal, between the two last rays.

2. Sicyopus multisquamäris de Bfrt.

Sicyopus multisquamatus de Beaufort, Zool. Anz. XXXIX p. 142.

D. VI. 11. A. 10. 1.1. about 55, 1.tr. about 14 .

Body elongate, rather more depressed than compressed. The height of the body is contained a little more than 8 times in the total length, almost $\%$ times in the length without caudal. Head flattened above, the upper profile horizontal from the first dorsal to the eye, then sloping to the point of the snout. The length of the head is contained $4 \frac{1}{2}$ times in the total length, almost $3^{3} / 4$ times in the length without caudal. The diameter of the eye is equal to the length of the snout and $1 / 4$ of the length of the head. The interorbital space is rather more than $1 \frac{1}{2}$ times the diameter of the eye. The cleft of the mouth is low

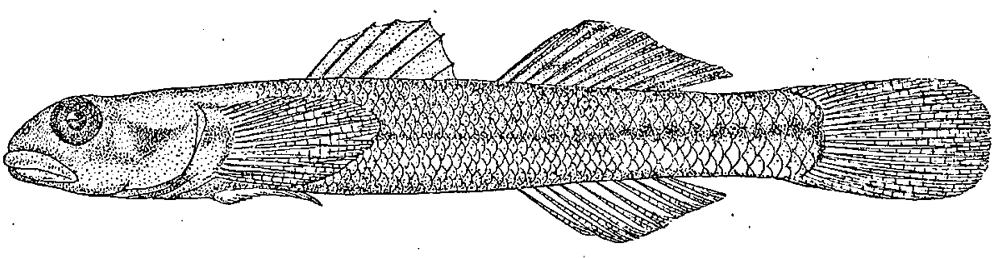

Fig. 7. Sicyopus mullisquamatus de Bfrt.

and horizontal, as in Sicyopterus. The entire upper lip and the sides of the lower lip are thick and swollen. The maxilla reaches a vertical through the middle of the eye. A single row of about 20 strong yellow-tipped teeth in the upper jaw. These teeth stand wide apart; they are pointed and strongly curved inwards. A similar row of teeth in the mandible, but here 
the teeth are much smaller and not curved. Isthmus broad. The first dorsal is short and much lower than the second one, from which it is widely separated. The first rays of the second dorsal are as high as the body in front, but the last rays are much shorter.

The anal is not so high as the second dorsal, the first rays are the longest. The caudal is truncated, its length is a little more than $1 / 6$ of the total length. The rounded pectorals are shorter than the head. The ventrals are shaped as in Sicyopterus, but only the centre of the disk is adnated to the belly. Its length is almost equal to half the length of the head. Scales on neck and belly cycloid and small, on the hinderpart of the sides and on the tail large and strongly ctenoid. Head naked; the scales reach to the sides of the occiput, but they are here almost hidden in the skin and scarcely perceptible. Colour in spirits yellowish. A triangular blackish spot on the operculum. A dark band along the sides. Rays of the dorsal fins dark. Anal colourless.

1 spec., $58 \mathrm{~mm}$, from a brook in the mountains near Honitetu, W. Ceram. February 19. 1910.

This species is easily distinguished from the other species of the genus by the great number of scales in the l.l. and l.tr.

\section{Sicyopterus Gill.}

1. Sicyopterus longifilis de Bfrt.

Sicyopterus longifilis de Beaufort, Zool. Anz. XXXIX p. 140.

D. VI. 11. A. 11. P. 19. 1.1, about 66, 1.tr. $1 \%$.

The height of the body is contained 6 times in the total length, 5 times in the length without caudal. The length of the head is contained $4^{3} / 5-5$ times in the total length, $3^{3} /_{4}-4$ times in the length without caudal. The eye is nearly situated in the middle of the length of the head. Its diameter is $1 / 5-1 \%$ of the length of the head. The eyes are 2 times their

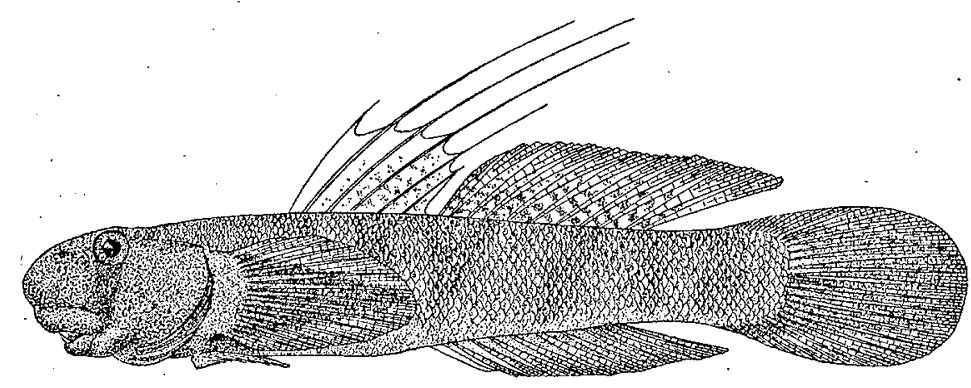

Fig. 8. Sicyopterus longifilis de Bfrt. diameter apart. The rounded snout is 2 times as long as the eye. The maxilla reaches under the front border of the eye. Upperlip without median cleft. Teeth in the upper jaw tricuspid. There are 8 strong teeth on each side in the lower jaw, besides two canines in front. The head is naked, except the occiput. Scales of occiput, neck and belly cycloid, the rest ctenoid. There are about 25 scales in front of the first dorsal. These scales and those along the shoulder and on the belly are smaller than those on the sides of the body and on the tail. The two dorsals are very close together. The $2^{\text {nd }}, 3^{\text {rd }}, 4^{\text {th }}$ and $5^{\text {th }}$ ray of the first dorsal are filamentous and excessively long, being rather more than half the length of the body without caudal. The second dorsal is higher than the body and pointed behind. The anal is like the dorsal, but much lower, its height being less than that of the body. Caudal rounded, longer than head. Pectorals pointed, as long as the head. The diameter of the ventral disk is the half of the length of the pectoral.

Colour in spirits brownish, whitish on the belly and at the underside of the head, the chin however being blackish. $\%$ or 8 indistinct dark transverse bands on the back. A black stripe running from the eye to the corner of the mouth. First dorsal whitish, with an indistinct dusky spot between the third and fifth ray. The hinderpart of the first dorsal and the whole of the second dorsal variegated with dusky dots. Caudal blackish, its upper and under margin broadly edged with white. Pectorals blackish, with a broad clear white margin, narrowing towards the tip. Ventrals white. 
3 spec., 49-97 mm, upper course of river Tuba, W. Ceram, February 2\%. 1910.

This species differs from all other Indo-australian Sicyopterus by the enormous development of its dorsal fins. It seems to be closely allied to S. pugnans 0. Grant from Savaii, from which it differs in being less elongate, in having tricuspid in stead of bicuspid teeth in the upper jaw and in having a greater number of scales in the linea lateralis and transversalis. According to the figure there is also a difference in the place of the eye, which is represented as being nearer to the tip of the snout than to the hind margin of the operculum.

1. Sicyopterus brevis de Bfrt.

Sicyopterus brevis de Beaufort, Zool. Anz. XXXIX p. 141.

D. VI. $11-12$. A. 12. 1.l. about 62 , 1.tr. about 16 .

'J'he height of the body is contained $5 \frac{1}{2}$ times in the total length, $4 \frac{3}{5}$. times in the length without caudal. The length of the head is contained $4 \frac{1}{2}$ times in the total length, $3^{3} /_{4}$ in the length without caudal. The eye is situated in the middle of the length of the head. The diameter of the eye is $1 / 4$ of the length of the head. The eyes are $11 / 2$ times their diameter apart. Upperlip without median cleft. No papillae on the gum beneath the upper lip. Teeth in the upper jaw tricuspid. The first and the two last mandibular teeth caninoid, the middle ones minute. The maxilla does not reach quite so far as a vertical through the middle of the eye. Head naked, except the occiput. The cycloid scales on the occiput and neck and on the belly are smaller than the ctenoid ones along the sides of the body and on the tail. The length of the third and longest ray of the first dorsal is equal to the height of the body. Second dorsal and anal much shorter than the height of the body. The pectoral is shorter than the head. The longitudinal diameter of the ventral disk is more than the half of the length of the head. Colour in spirits yellowish. A dark longitudinal band along the sides of the body, and another interrupted zig-zag-shaped one, which is less distinct, at each side along the back. An indistinct dusky spot between the third and fourth ray of the first dorsal. Second dorsal obliquely striped with blackish, anal white with a dark subterminal band Caudal with an indistinct median stripe (a continuation of the band along the sides of the body) and with traces of a horse-shoe-shaped submarginal band. A dark stripe runs from the eye to the corner of the mouth.

2 spec., 44 and $45 \mathrm{~mm}$, upper course of river Tuba, W. Ceram, February 2\% 1911.

This species is distinguished by its short body. It seems to be allied to S.taeniurus Gthr., but differs in having smaller scales, in having a shorter pectoral etc.

Periophthalmus Bl. Schn.

1. Periophthalmus koelreuteri (Pall.).

Gobius koelreuteri Pallas, Spicil. VIII p. 8.

Periophthialmus koelreuteri Günther, Cat. Brit. Mus. III p. $9 \%$.

16 spec., 42-103 mm, Saonek, December 18. 1909.

1 spec., $50 \mathrm{~mm}$, Sorong, N. Guinea, January 1910 (L. de Bruyn leg.).

13 spec., 63-82 mm, Kairatu, W. Ceram, February 16. 1910.

11 spec., 42-\%2 $\mathrm{mm}$, Ambon.

Taenioides Lac.

1. Taenioides spec.

2 spec., 20-34 mm long, Kairatu, W. Ceram, brackish water, February 16. 1910.

These two small specimens seem to be allied to Taenioides urolepis Blkr., they have however no trace of scales. 


\section{Scorpaenidae}

Sebastes C. V.

1. Sebastes (Sebastopsis) guamensis (Q. G.).

Scorpaena guamensis Quoy et Gaimard, Voyage Uranie, Zool. p. 325.

Scorpaena guamensis Günther, Fische der Südsee, p. 74.

Sebastopsis polylepis Bleeker, Verh. Kon. Akad. Amsterdam XVI p. 21.

Sebastopsis guamensis Jordan \& Seale, Bull. Bur. Fish. XXV p. $3 \% 4$.

2 spec., 88 and $20 \mathrm{~mm}$, from the reef at Saonek, December 1909 and January 1910.

Scorpaena Artedi.

1. Scorpaena novae-guineae C. V.?

Scorpaena Novae-Guineae Cuvier \& Valenciennes, Hist. Nat. Poiss. IV p. 320.

Scorpaenopsis Novae-Guineae Bleeker, Verh. Akad. Amsterdam XVI p. 35.

2 juvenile specimens, 23 and $33 \mathrm{~mm}$ long, from Saonek, probably belong to this species.

Gymnapistus Swainson.

1. Gymnapistus niger (C. V.).

Apistus niger Cuvier \& Valenciennes, Hist. Nat. Poiss. IV p. 415.

Gymnapistus niger Bleeker, Verh. Kon. Akad. Amsterdam XVI p. 86.

One young specimen of $18 \mathrm{~mm}$, from Kairatu, W. Ceram. February 16. 1910.

\section{Platycephalidae.}

Patycephalus Bl. Schn.

1. Platycephalus bobossok Blkr.

Platycephalus bobossok Bleeker, Nat. Tijdschr. Ned. Indië IV p. 461.

Platycephalus bobossok Bleeker, Verh. Kon. Akad. XIX, Platycephalus, p. 23.

1 spec., $73 \mathrm{~mm}$, from the fishmarket at Macassar, March 11. 1910.

\section{Triglidae.}

Parapercis Bleeker.

1. Parapercis cylindrica (Bl.).

Sciaena cylindrica Bloch, Ausländ. Fische VI p. 42.

Percis cylindrica Günther, Cat. Brit. Mus. II p. 239.

3 spec., 83-102 mm, Saonek, December 1909.

Blenniidae.

Salarias Cuvier.

1. Salarias amboinensis Blkr.

Salarias amboinensis Bleeker, Act. Soc. Scient. Ind. II p. $6 \%$.

2 spec., 5\%-110 mm, Saonek, December 1909.

1 spec., 103 mm, Ambon, February 1910. 
2. Salarias surnatranus Blkr.

Salarias sumatranus Bleeker, Nat. Tijdschr. Ned. Indië I p. 256.

Salarias sumatranus Max Weber, Siboga-Exp. Fische p. 531.

1 spec., $100 \mathrm{~mm}$, from the reef at Saonek, December 1909.

3. Salarias striatomaculatus Kner \& Steind.

Salarias striatomaculatus Kner \& Steindachner, Sitz. ber. Akad. Wien. LIV p. 368.

Salarias striatomaculatus Bleeker, Versl. Akad. Amsterdam 2de Reeks, XII p. 6.

Salarias striatomaculatus Max Weber, Siboga-Exp. Fische p. 531.

1 spec., $99 \mathrm{~mm}$, from Sorong, New Guinea. L. de Bruyne leg. January 1910.

My specimen differs from that mentioned by Max Weber, with which I was able to compare it, in the fact of having a crest on the head (probably characteristic of the male) and in having the dorsal and anal broadly margined with brownblack.

4. Salarias interruptus Blkr.

Salarias interruptus Bleeker, Nat. Tijdschr. Ned. Indië XIII p. 68.

4 spec., from the reef at Saonek, December 1909.

5. Salarias lineatus C. V.

Salarias lineatus Cuvier \& Valenciennes, Hist. Nat. Poiss. XI p. 314.

Salarias lineatus Bleeker, Verh. Bat. Gen. XXIII p. 18.

Salarias lineatus Day, Fishes of India $4^{\circ}$. p. 332.

5 specimens, 46-88 mm, from the reef at Saonek, December 1909.

6. Salarias rivulatus Rüpp.

Salarias rivulatus Rüppell, Atl. Reise Nordl. Afrika p. 114.

Salarias quadricornis Cuvier \& Valenciennes, Hist. Nat. Poiss. XI p. 329.

15 spec., 24-69 mm, from the reef at Saonek, December 1909.

7. Salarias bilitonensis Blkr.

Salarias bilitonensis Bleeker, Nat. Tijdschr. Ned. Indië XV p. 231.

2 spec.. $44-63 \mathrm{~mm}$, from the reef at Saonek, December 1909.

8. Salarias spec.

2 spec., 34 and $38 \mathrm{~mm}$, from the reef at Saonek, December 1909.

I am not able to range these two young specimens under one of the known species. They show some affinity to $S$. periophthalmus, but lack canini, have simple nasal tentacles, while some of the dorsal and caudal rays are produced.

I think it safer not to describe these half-grown specimens as a new species, in order not to create still more confusion in the species of the genus Salarias. Prof: Weber and I will have to work out the Indo-australian species of the genus Salarias for our "Fishes of the Indo-australian Archipelago" therefore I will postpone further reseach to the future.

\section{Petroscirtes Rüppell.}

1. Petroscirtes grammistes (C. V.)

Blennechis grammistes Cuvier \& Valenciennes, Hist. Nat. Poiss. XI p. 284.

Petroskirtes anema Bleeker, Nat. Tijdschr. Ned. Indië III p. 2\%3.

Petroscirtes anema Günther, Cat. Fishes Brit. Mus. III p. 236.

Petroscirtes grammistes Günther, Südseefische, p. $19 \%$. 
18 spec., $32-55 \mathrm{~mm}$ long, river Batu merah, Ambon, March 1910.

25 spec., 21-74 mm long, river Mirdika, Ambon, December 1909, February 1910.

2 spec., 21-47 mm long, Kairatu, W. Ceram, February. 16. 1910, brackish.

All the larger specimens and a good deal of the smaller ones differ from the descriptions of the authors cited above in the following points: Presence of small suborbital tentacles, 8 interorbital tentacles, four of which are situated in a row in front, the four others placed more backwards in the corners of a square. A pair of small tentacles in front of the dorsal fin on the vertex, and half a dozen on each side along the outer edge of the praeoperculum. Two small barbels on the chin. The middle ray of the ventral fin mostly produced, sometimes very much so: The head dark violet, without traces of the lower of the three longitudinal dark bands. This band is diffuse on the body, of a violet colour, sometimes almost absent. It reappears however on the tail. The light interspace between the bands yellow. Dorsal fin with its outermargin greyish, separated from the broad black band along the base of the fin by a white interspace, obsolated in front between the $2^{\text {nd }}$ to the $6^{\text {th }}$ spine, but reappearing between the first and second spine, where the outermargin of the fin is deep black. A subterminal black band along the anal fin, and a dusky one along its base.

I suppose that the fishes with the pecularities described above are the males and the other ones the females. I dissected two specimens of each variety which proved to be of the expected sex in these four cases.

The females agree with the descriptions given by Bleeker and Günther, but some of them have a diamond-shaped black marking on the undersurface of the head.

\section{Batrachidae.}

Batrachus Bl. Schn.

1. Batrachus grunniens (L.) Cottus grunniens, var. B. Linné, Mus. Ad. Fried. II p. 65. Batrachus grunniens Günther, Cat. Brit. Mus. III p. 168. Batrachus Gangene Day, Fishes of India $4^{\circ}$ p. 270.

1 spec., $200 \mathrm{~mm}$, from the fishmarket at Macassar, March 12. 1910.

2. Batrachus diemensis (Lesueur).

Batrachoides diemensis Lesueur, Journ. Acad. Nat. Sc. Philadelphia, III p. 402.

Batrachus diemensis Richardson, Voyage Erebus \& Terror, Fishes p. $1 \%$.

Batráchus diemensis Günther, Cat. Brit. Mus. III p. $1 \% 0$.

4 spec., 78-108 mm, Beo, Majalibit-bay, Waigeu, January 1910.

Antennariidae.

Antennarius Commerson.

1. Antennarius spec. juv.

One specimen from Ambon, long $22 \mathrm{~mm}$, February 1910.

Triacanthus Cuvier.

1. Triacanthus blochi Blkr.

Triacanthus blochi Bleeker, Nat. Tijdschr. Ned. Indië, III p. 81. Atl.' Ichh. V p. 89.

Triacanthus blochi Tate Regan, Proc. Zool. Soc. 1903 p. 182.

2 spec., 95 and $89 \mathrm{~mm}$, Macassar, fishmarket, March 11. 1910. 


\section{Balistes L.}

1. Balistes viridescens Bl. Schn.

Balistes viridescens Bloch, Schneider, Syst. Ichth. p. $47 \%$

Balistes (Pseudobalistes) viridescens Bleeker, Atl. Ichth. V p. 112.

2 spec., 65 and $130 \mathrm{~mm}$, from Ambon, February 1910.

2. Balistes undulatus Mungo Park.

Balistes undulatus Mungo Park, Trans. Linn. Soc. III p. 3\%.

Balistapus lineatus Bleeker, Atl. Ichth. V p. 118.

Balistes undulatus Günther, Cat. Brit. Mus. VIII p. 226.

1 spec., $155 \mathrm{~mm}$, from Saonek, January 15. 1910.

3. Balistes aculeatus $\mathrm{L}$.

Balistes aculeatus Linné, Syst. Nat. Ed. X p. 328.

Balistapus aculeatus Bleeker, Atl. Ichth. V p. 102.

1 spec., $139 \mathrm{~mm}$, from Saonek.

4. Balistes verrucosus L.

Balistes verrucosus Linné, Syst. Nat. Ed. X p. 328.

Balistapus verrucosus Bleeker, Atl. Ichth. V p. 120.

1 spec., $152 \mathrm{~mm}$, from Saonek.

2 spec., 94 and $118 \mathrm{~mm}$, from Ambon.

Monacanthus Cuvier.

1. Monacanthus tomentosus (L.).

Balistes tomentosus Linné, Syst. Nat. Ed. X p. 328.

Monacanthus hajam Bleeker, Atl. Ichth. V p. 126.

Monacanthus tomentosus Bleeker, Atl. Ichth. V p. $12 \%$

Monacanthus tomentosus Günther, Cat. Brit. Mus. VIII p. 238.

2 spec., 52 and $82 \mathrm{~mm}$, from the fishmarket at Ambon.

24 spec., 70-106 mm, from the Majalibit-bay, Waigeu, January 1910.

1 spec., $65 \mathrm{~mm}$, from Sorong, New Guinea, January 1910 (L. de Bruyne leg.).

2. Monacanthus chinensis (Bl.).

Balistes chinensis Bloch, Ausl. Fische II p. 29.

Monacanthus chinensis Bleeker, Atl. Ichth. V p. 125.

1 spec., $122 \mathrm{~mm}$, from Sorong, New Guinea, January 1910 (L. de Bruyne leg.).

1 spec., $11 \mathrm{~mm}$, from the fishmarket at Macassar, March 11. 1910.

\section{Ostracion L.}

1. Ostracion cornutus L.

Ostracion cornutus Linné, Syst. Nat. Ed. X p. 331.

Ostracion arcus Bleeker, Atl. Ichth. V p. 35.

Ostracion cornutus, Günther, Cat. Brit. Mus. VIII p. 265.

] spec., $155 \mathrm{~mm}$, Ambon, February 1910.

1 spec., $61 \mathrm{~mm}$, Macassar, fishmarket, March 1910. 


\section{Tetraodontidae.}

Tetraodon L.

1. Tetraodon hispidus L.

Tetraodon hispidus Linné, Syst. Nat. Ed. X p. 333.

Crayracion implutis Bleeker, Atl. Ichth. V p. 71.

Tetraodon hispidus Günther, Cat. Brit. Mus. VIII p. 29\%.

Tetraodon hispidus Day, Fishes of India $4^{\circ}$ p. $\% 06$.

Tetraodon hispidus Günther, Fische der Südsee, Bd. III p. $46 \%$.

1 spec., $145 \mathrm{~mm}$, Saonek.

1 spec., 1 \%3 mm, Majalibit-bay, Waigeu, January 1910.

3 spec., 32- $165 \mathrm{~mm}$, Ambon.

Both specimens have a black anal ring. This is not in accordance with Bleeker's statement "ano annulo nigro nullo". Günther however (Fische d. Südsee) mentions this ring in some of his varieties.

2. Tetraodon immaculatus Bl. Schn.

Tetrodon immaculatus Bloch, Schneider, Syst. Ichth. p. $50 \%$

Crayracion immaculatus Bleeker, Atl. Ichth. V p. 75.

Crayracion manillensis Bleeker, Atl. Ichth. V p. 69.

Tetrodon immaculatus Günther, Cat. Brit. Mus. VIII p. 291.

6 spec., $150-95 \mathrm{~mm}$, Majalibit-bay, Waigeu, January 1910.

1 spec., $90 \mathrm{~mm}$, Sorong, New Guinea (L. de Bruyne leg. January 1910).

All -my specimens are of the striped variety (manillensis), which is considered to be the juvenile dress of $T$. immaculatus.

3. Tetraodon erythrotaenia Blkr.

Tetraodon erythrotaenia Bleeker, Nat. Tijdschr. Ned. Indië V p. 174.

Crayracion erythrotaenia Bleeker, Atl. Ichth. V p. 68.

Tetrodon erythrotaenia Max Weber, Abh. Senckenb. Naturf. Gesellsch. XXXIV p. 48.

10 spec., $52-74 \mathrm{~mm}$, from the river Mirdika, Ambon, February 1910.

4. T'etraodon patoca Ham. Buch.

Tetrodon patoca Hamilton Buchanan, Fish. Ganges, p. $\%$.

Leioclon patoca Bleeker, Atl. Ichth. V p. 76.

Tetrodon patoca Günther, Cat. Brit. Mus. VIII p. 288.

1 spec., $55 \mathrm{~mm}$, River Waiu waigé, Waigeu, freshwater under influence of tide, Dec. 25. 1910.

2 spec., 200-68 mm, Majalibit-bay near Beo, Waigeu, January 1910.

5 spec., 62-14 mm, Kairatu, West Ceram, brackish water, February 16. 1910.

4 spec., Ambon, February 1910.

3 spec., Batu merah, Ambon, March 1910. 


\section{General part.}

The chief importance of the collection, described above, lies in the fact that it contains a number of freshwater-fishes from different islands in the eastern part of the Indo-Australian archipelago, viz. from Buru, Ceram, Batjan, Halmahera, Ambon and Waigeu.

The fishes collected at Batjan, during the few hours of our visit, belong to only three species:

Kuhlia marginata (C. V.)

Therapon rosenbergii Blkr.

Stiphodon elegans (Steind.)

They were caught in a mountain-stream, which flows into the bay of Batjan. Only the first one of these three has been previously recorded from this island by Bleeker, who gave two lists of freshwater-fishes from Batjan ${ }^{1}$ ). The two others are not mentioned either by Max Weber in his table of the distribution of the freshwater-fishes of the Indo-Australian archipelago ${ }^{2}$ ) or by Steindachner in the record of the fishes collected by Külkenthal on that island ${ }^{3}$ ).

Max Weber ${ }^{4}$ ) has given a list of the freshwater-fishes of Ambon. Among the fishes which I collected there in freshwater and estuaries, the following do not occur in that list:

1. Hemirhamphus dispar C. V.

2. Mugil rossi Blkr.

3. Platophrys pantherinus (Rüpp.)

4. Lutjanus biguttatus (C. V.)

5. Lutjanus ehrenbergi (Pet.)

6. Lutjanus argentimaculatus (Forsk.)

7. Apogon ceramensis Blkr.

8. Therapon rosenbergii Blkr.

9. Sillago sihama (Forsk.)

10. Caranx macrophthalmus Rüpp.

11. Acanthurus blochii C. $\mathrm{V}$.

12. Gobius puntang Blkr.

13. Gobius variabilis Steind.

14. Petroscirtes grammistes (C. V.).

15. Tetraodon hispidus L.

I have in my collection the following species from Halmahera, presented to me by the missionary G. A. Maan and obtained in a stream near Buli:

1. Mugil bleekeri Gthr.?

2. Lutjanus argentimaculatus (Forsk.)

3. Gobius celebius C. V.

None of them are either recorded in the list of Max Weber or by Steindachner from Kükenthal's collection.

From the lake Galela I got by the kind assistance of the missionary van Baarda the only species of fish, which is said to inhabit it:

Eleotris aporos Blkr.

Not much is known of the fish-fauna of Buru. Quoy \& Gaimard ${ }^{5}$ ) mentioned some marine species from Buru as well as Cuvier \& Valenciennes in the "Histoire naturelle des

1) Bleeker, Nat. Tijdschr. Ned. Indië VII, 1854, p. 359-378 and IX, 1855, p. 191-202.

2) Max Weber, Zoolog. Ergeb. einer Reise nach O. Indien. III, 1894, p. 447.

3) Steindachner, Abhandl. Senckenb. Naturf. Gesellsch. XXV, 1901, p. 413.

4) Max Weber, Zool. Ergeb. III, p. 440 and in Semon, Zool. Forschungsreisen in Australien und dem Malay. Archipel 1895 , p. 260.

5) Quoy \& Gaimard, Voyage de l'Uranie et de la Physicienne, Zool. Poissons. 1824. - Voyage de l'Astrolabe. Zool. III, 1834, p. 674 . 
Poissons". Bleeker ") has published several papers on the fishes of Buru, but it is not specially stated if specimens were caught in freshwater; generally nothing is said about the habitat, in other cases there is only stated that they came from the sea and estuaries near Kajeli. Lastly Forbes ${ }^{2}$ ) mentions a species of eel as the only fish inhabiting the lake Wokolo in the interior of the island. This is about all that is known about the fish-fauna of this island. The fishes which I collected in a stream near Kajeli not far from its mouth, will add but little to our knowledge. In the following list of the fishes obtained there, those with an * have not yet been recorded from Buru.

1. Anguilla mauritiana Benn.

*2. Coelonotus leiaspis (Blkr.)

*3. Doryrhamphus mento (Blkr.)

4. Doryrhamphus brachyurus (Blkr.)

*5. Doryrhamphus brevidorsalis de Birt.

*6. Doryrhamphus caudatus (Peters).

*\%. Mugil borneensis Blkr.

*8. Mugil ceramensis Blkr.

*9. Mugil subviridis C. V.

10. Kuhlia marginata (C. V.).

11. Kuhlia rupestris (Lac.)

12. Ambassis buroensis Blkr.

* 13. Ambassis commersoni C. V.

*14. Eleotris gyrinoides Blkr.

*15. Eleotris porocephalus C. V.

16. Eleotris hoedti Blkr.

1\%. Eleotris amboinensis Blkr.

18. Gobius giuris H. B.

*19. Gobius oyensi de Bfrt.

Little is also known with certainty about the freshwater-fishfauna of Ceram. Although Bleeker ${ }^{3}$ ) has given many contributions to our knowledge of the fishfauna of that island, only the of following ones are specially recorded as freshwater fishes. They were collected by von Rosenberg in the river Ruwata, which flows in the Elpaputih-bay, at the south coast of the island.

1. Mugil heterocheilos Blkr.

2. Agonostoma oxyrhynchum C. V.

3. Gymnothorax polyuranodon (Blkr.)

4. Lutjanus fuscescens (C. V.)

5. Kuhlia marginata (C. V.)

6. Therapon rosenbergii Blkr.

\%. Eleotris porocephalus $\mathrm{C} . \mathrm{V}$.

The fishes, which I collected at Ceram, are all from one river-system, viz. the Riuapa, which flows near Kairatu into the southern part of the Piru-bay. It comes from the mountains near Honitetu, where I visited its uppercourse, which has the character of a rapid mountain-torrent, rushing down on a rocky bed. Here it receives several brooks, which run in deep ravines and unite in the torrent Ėme, which again flows in the Riuapa. Another of its tributaries, the river Tuba, mixes its water with that of the Riuapa lower down. I also had an opportunity of fishing in the Tuba in that part of its course, where it leaves the mountain.

1) Bleeker, Nat. Tijdschr. Ned. Ind. XI. 1856, p. 383-414. ibid. XIII. 1857, p. 55-82. ibid. XXII. 1861, p. 109-114. Ned. Tijdsch. Dierk. II. 1865, p. 141-151.

2) Forbes., Wanderungen eines Naturforschers im Malay. Archipel. II. 1886. p. 115.

3) Bleeker, Nat. Tijdschr. Ned. Ind. III. 1852, p. 229-309, p. 689-714. ibid. V. 1853, p. 233-248. ibid. XI. 1856, p. 486-487. ibid. XII. 1856-1857, p. 508. ibid. XXII. 1861, p. 228-238. Ned. Tijdschr. Dierk. I. 1863, p. 252-261. ibid. II. 1865 , p. $182-193$. 
In the accompanying table the distribution of the fishes collected in the Riuapa and its tributaries is shown. Certainly the list of fishes is very far from being complete, especially of those of the lower part of the river, where I only collected during an hour or so near its mouth and in a clear, gently flowing brook in the lowland, the Krikua, a left tributary of the Riuapa.

Out of this table may be seen that the Gobiidlae ascend the rivers farthest and especially those with a well-developed ventral disk, as the different species of Sicyopterus and Sicyopus as well as Stiphodon elegans, Microsicydium gymnauchen and Rhiacichthys aspro, which are all probably able to resist the rapid current by attaching themselves to the stones in the bed of the river.

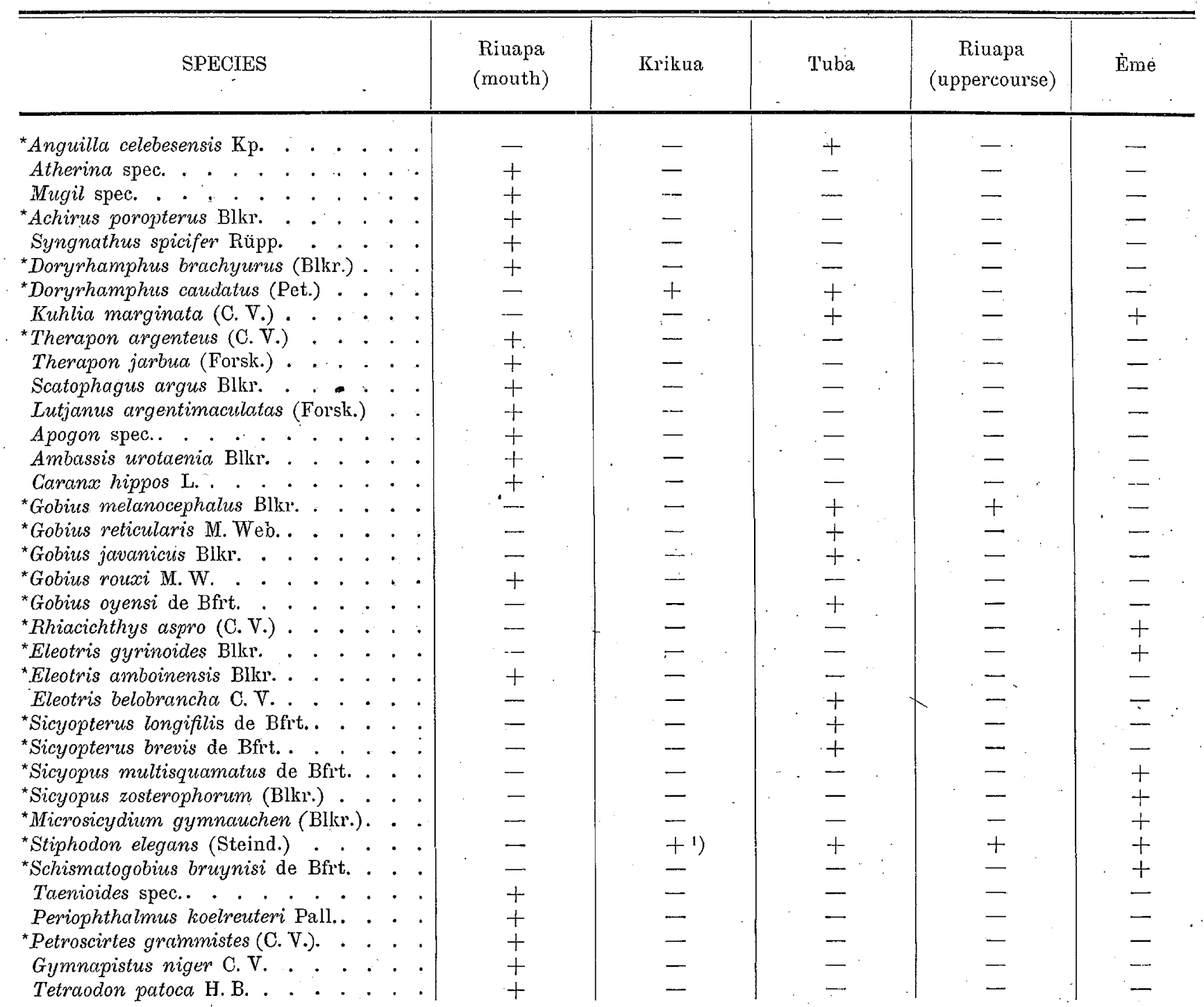

Kuhlia marginata however was also met with in the highest parts of the rivers, where it was actually seen to leap through the rapids from one pool to the other.

In these wild streams eels and sea-needles were not found, but Anguilla celebesensis Kp. and Doryrhamphus caudatus (Peters) ascend as far as where the rapids begin, as may be demonstrated by their capture in the river Tuba.

Freshwater-fishes from Waigeu where not known with certainty before I visited the island. In fact all that was known of the ichthyological fauna of this island were the species reported by Lesson ${ }^{2}$ ) from the voyage of "La Coquille" and by Quoy \& Gaimard

1) Only seen, not captured.

2) Lesson, Voyage autour du monde sur La Coquille, Zoologie 1830 
from that of "L'Uranie" et "la Physicienne", as well as some species mentioned by Cuvier \& Valenciennes and by Bleeker ${ }^{1}$ ), who published the list of fishes collected by Bernstein on that island. Lastly the Siboga-expedition visited Waigeu, and some fishes of that locality are mentioned in Max Weber's report on the fishes of that expedition.

None of them however are from freshwater. All of the fishes mentioned by Lesson were captured „dans la baie d'Offach". Those described by Quoy \& Gaimard are only stated to be caught at Waigeu, without indication whether they came from the sea, estuaries or freshwater and the same can be said of those collected by Bernstein. It is however probable that the following species came from freshwater or at least estuaries:

1. Eleotris fusca Bl. (= Eleotris niger Q. G.)

2. Eleotris hoedti Blkr.

Anguilla marmorata of Quoy \& Gaimard ought perhaps to be mentioned here too, but it is very doubtful if the species described by these authors from Waigeu really is an Anguilla (cf. Max Weber. Zool. Jahrb. Suppl. I. 1912, p. 580).

The rivers and brooks which $I$ have explored in Waigeu are the following:

$1^{\circ}$. River Waiu waigé, which flows into the bay Tip waigé. The place where I collected was not far from its mouth, where the river flows through a rather swampy forest, in which here and there isolated rocks arise. The species collected are:

1. Anguilla spec. juv.

2. Apogon amboinensis Blkr.

3. Eleotris (Butis) butis H. B.

4. Eleotris (Culius) spec. juv.

$2^{\circ}$. River Waihă, at the south coast of the island. For the greater part it finds its way to sea through the limestone-rocks, which here come down to the coast. Its course is thus short and steep. All the species were collected above the rapids.

1. Sphagebranchus mindora Jord. \& Rich.

2. Anguilla spec. juv.

3. Gobius reticularis M: Web.

4. Eleotris hoedti Blkr.

5. Eleotris fusca Bl. Schn.

6. Eleotris melanosoma Blkr.

3. River Waisa, also at the south coast and of about the same condition as the foregoing.

1. Eleotris gyrinoides Blkr.

2. Eleotris hoedti Blkr.

3. Eleotris fusca Bl. Schn.

$4^{\circ}$. A rapidly flowing brook, forming several small waterfalls, near Mumes, south coast of Waigeu.

1. Eleotris hoedti Blkr.

2. Eleotris fusca Bl. Schn.

The following rivers all flow into the Majalibit-bay, which almost divides Waigeu in two parts and only communicates by a rather narrow passage with the open sea. Notwithstanding the circumstances which make one assume that the water of this bay, which has quite the aspect of a lake, is more or less fresh, this is not the case and its water is strongly brackish. I collected severa] fishes in the end of the bay, near the island Beo, which all prove the brackish character of their habitat, as may be seen from the following list:

1. Atherina duodecimalis C. V.

2. Atherina endrachtensis Q. G.

3. Hemirhamphus quoyi C. V.

4. Hemirhamphus buffonis C. V.

5. Aeoliscus strigatus (Gthr.)

6. Apogon melas Blkr.

1) Bleeker, Versl. Akad. Amsterdam (2) II. 1868, p. 295-301, ibid. p. 331-335. 
\%. Apogon sangiensis Blkr.

8. Apogon ceramensis Blkr.

9. Apogon orbicularis Blkr.

10. Cheilodipterus singapurensis Blkr.

11. Ambassis dussumieri C. V.

12. Lutjanus biguttatus (C. V.)

13. Caesio maculatus C. V.

14. Therapon puta C. V.

15. Gerres oyena (Forsk.)

16. Gazza argentaria (Forst.)

1\%. Amphacanthus javus L.

18. Platyglossus hyrtli (Blkr.)

19. Platyglossus bicolor (Bl. Schn.)

20. Pomacentrus trilineatus C. V.

21. Caranx hippos L.

22. Caranx affinis Rüpp.

23. Chorinemus lysan (Forsk.)

24. Gobius puntang Blkr.

25. Eleotris aruensis M. Web.

26. Batrachus diemensis Lesueur

2\%. Monacanthus tomentosus (L.)

28. Tetraodon patoca H. B.

29. Tetraodon hispidus L.

30. Tetraodon immaculatus Bl. Schn.

The following rivers, which flow into the Majalibit-bay, were explored.

$5^{\circ}$. River Rabiai, flowing on a gravel-bed in a narrow canion-like valley.

1. Syngnathus spicifer Rüpp.

2. Coelonotus leiaspis (Blkr.)

3. Rhombatractus catherinae de Bfrt.

4. Ambassis urotaienia Blkr. (mouth of river).

5. Gobius reticularis M. Weber.

6. Gobius melanocephalus Blkr.

\%. Eleotris fusca Bl. Schn.

$6^{\circ}$. River Bajon (gravel-bed.)

1. Rhombatractus catherinae de Bfrt.

2. Gerres filamentosus C. V. (near mouth).

3. Eleotris fusca Bl. Schn.

go. Wai-semi, a side river of the Kaiawat (gravel-bed, flowing through rather level forest).

1. Rhombatractus catherinae de Bfrt.

$8^{\circ}$. Wai-menil (uppercourse torrent-like, undercourse on gravel-bed).

1. Rhombatractus catherinae de Bfrt. (upper and undercourse).

2. Eleotris aruensis M. Web. (undercourse):

The only locality from the north coast, where I collected, was:

$9^{\circ}$. river Lam-lam, a clear brook in level forest, which flows into the Fofak-bay.

1. Kuhlia marginata (C. V.)

In the table on page $158 \mathrm{I}$ have given a list of all the fishes now known to inhabit the freshwater of the islands which I visited and those in the neighbourhood, in fact including the principal islands between the Greater Sunda-islands and New Guinea, only excepting Celebes. I have excluded this island from my list, as new contributions to the freshwater fish-fauna of this island will shortly be published by Prof. Max Weber.

As a base for this table I have used that given by Weber (l. c. antea), but I have only recorded here those species, which are known from freshwater and excluded from the list those which are found in brackish water and the sea only, or have accidently been found 
in freshwater. The list is further brought up to date by entering the fishes recorded by Kükenthal (l. c. antea) from Batjan, Halmahera, by Max Weber ${ }^{1}$ ) from the Aru- and Keiislands, by Miss Popta ${ }^{2}$ ) from Lombok and Sumbawa and by Max Weber and myself ${ }^{3}$ ) from Timor and Babber, as well as those recorded in this paper from the islands mentioned above.

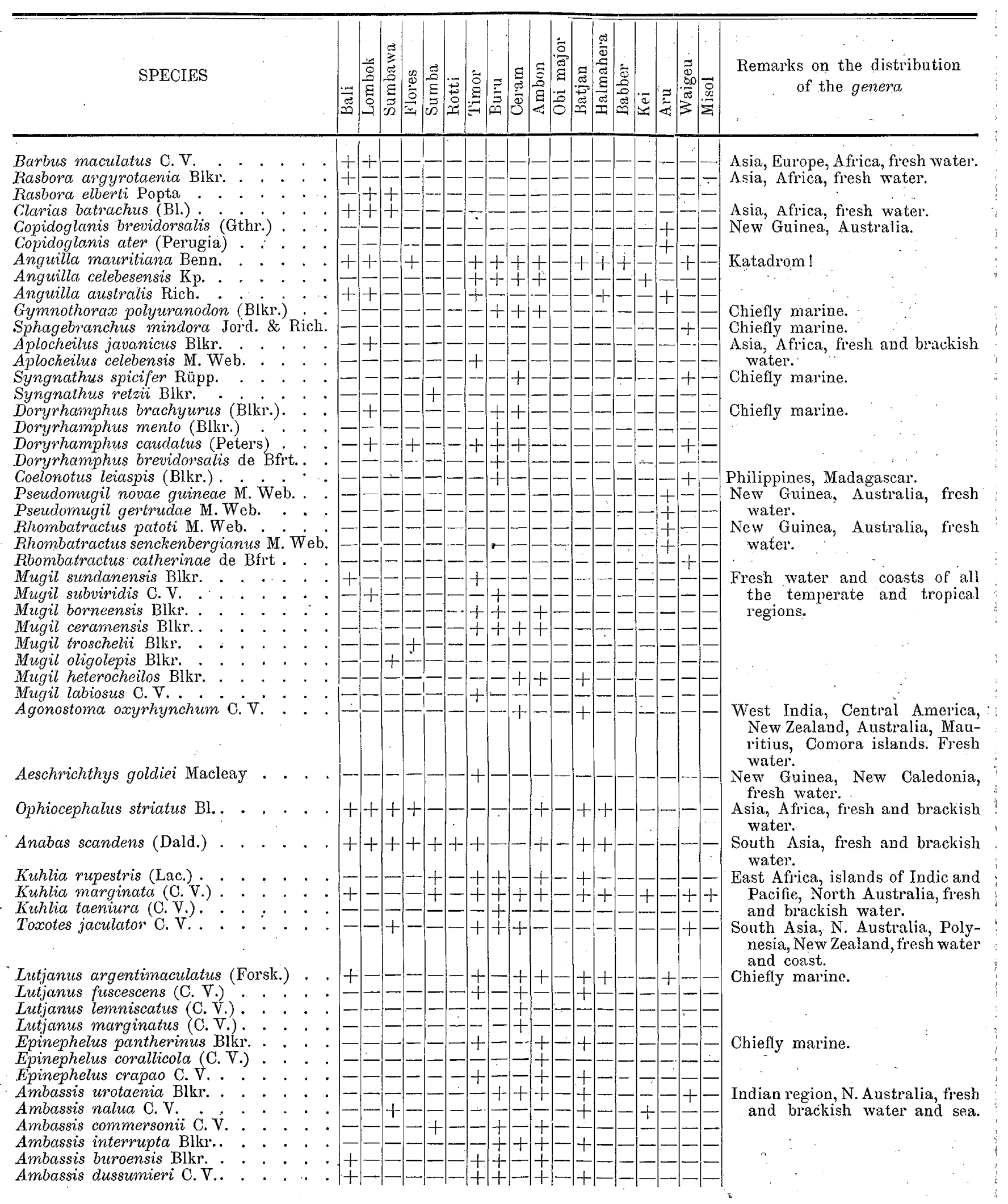

1) Max Weber, Abhandl. Senckenberg. Naturf. Gesellsch. XXXIV. 1911, p. 1.

2) Popta, Notes Leyden Museum XXXIV. Note III 1911, p. 9-16. - Verhandl. d. 83. Versamml. Deutsche Naturf. u. Aerzte 1911. II. 1. Hälfte, p. 418. - In Dr. J. Elbert: "Die Sunda-Expedition". II. p. 315.

3) Max Weber \& L. F. de Reaufort; Versl. Akad. Amsterdam 1912, p. 133 


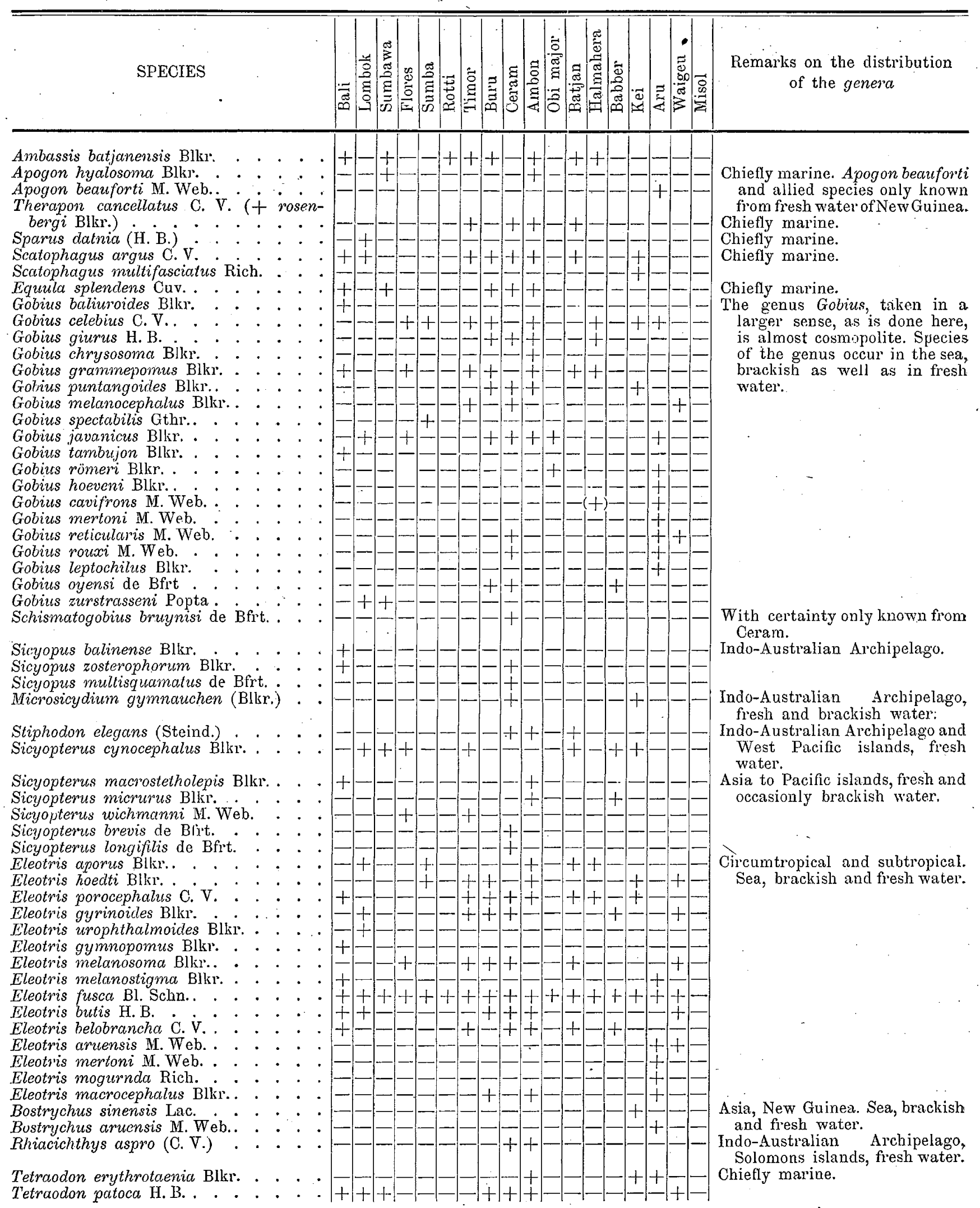

An examination of this list will lead us to the same result as to which previous authors came, and which is best expressed as follows: $1^{\circ}$ The freshwater-fishfauna of the islands between the Greater Sunda-islands and New Guinea is chiefly constituted of marine lishes, which took possession of the available freshwater as invaders from the sea. $2^{\circ}$ True fresh water fish-families are lacking, but some indian forms (Anabas scandens (Dald.), Ophiocephalus striatus Bl., Aplocheilus javanicus Blkr.) have been able to, extend their range more or less 
eastward. $3^{\circ}$ Some islands in the neighbourhood of New Guinea have an australian element in their freshwater-fishfauna (Rhombatractus, Pseudomugil, both members of the Melanotaeniidae and Copidoglanis). I will now proceed to a closer examination of these 3 elements in the fishfauna of these islands and begin with the $3^{\text {rd }}$. Max Weber ${ }^{1}$ ) has pointed out the significance of the occurrence of Melanotaenïdae in New Guinea. The members of this family, probably derived from marine Atherinidae, are true freshwater fishes, and their occurrence in Australia as well as on New Guinea is a confirmation of the opinion, that New Guinea and Australia have been connected by a landbridge. The reason why Max Weber thought it probable that this connection existed in the pliocene, whereas it disappeared in the pleistocene, may be found for in the paper quoted. In this paper the author expressed the probability that the Aru- and Kei-islands as well as Waigeu - in view of what was known of their fauna would yield Melanotaeniidae. The confirmation of this prophecy was brought shortly afterwards by Weber himself for the Aru-islands ${ }^{2}$ ) and by myself for Waigen ${ }^{3}$ ), but in the case of the Kei-islands the result turned out to be otherwise. The collections made by Dr. H. Merton and Dr. J. Roux in the Aru- and Kei-islands gave Weber ${ }^{4}$ ) the opportunity of showing the marked difference in the fisbfauna of these islands. In the case of the Aru-islands a strictly papuan fauna, not only on account of the Melanotaeniidae but also on that of the Siluridae (Copidoglanis) and even perceivable in the Gobiidae was shown to exist, whereas the scanty brooks and rivers on the Kei-islands are only inhabited by marine invaders of a more western (indian) character.

This marked difference between the fauna of the Aru- and Kei-islands is also apparent in other groups of animals. Hartert ${ }^{5}$ ) expressed it in reference to the birds of these islands. Roux ${ }^{6}$ ) and Barbour ${ }^{7}$ ) pointed out the occurrence of an indian element in the reptilian fauna of the Kei-islands, which is wanting in that of the Aru-islands. At a meeting of the "Nederlandsch Natuur- en geneeskundig Congres" in 1911 I $^{8}$ ) read a paper on the zoogeography of the eastern part of the Indo-Australian Archipelago, in which I gave the following table on the distribution of the birds; migrants, sea-birds etc. being excluded:

\begin{tabular}{|c|c|c|c|c|}
\hline & ENDEMIC SPECIES & $\begin{array}{l}\text { Species also found } \\
\text { IN NEW GoINEa. }\end{array}$ & $\begin{array}{l}\text { SPECIES WITH AFFINitIES } \\
\text { TO THE ORIENTAL REGION }\end{array}$ & $\begin{array}{c}\text { SPECIES OF } \\
\text { WIDE DISTRIBUTION }\end{array}$ \\
\hline $\begin{array}{l}\text { Waigeu . } \\
\text { Batanta .. } \\
\text { Salawatti . } \\
\text { Misol. . . } \\
\text { Aru-Islands } \\
\text { Kei-Islands } \\
\text { Ceram . . . } \\
\text { Halmahera }\end{array}$ & $\begin{array}{l}14 \% \\
9 \% \\
0 \% \\
2 \% \\
7 \% \% \\
30 \% \\
56.4 \% \\
54 \%\end{array}$ & $\begin{array}{l}66.6 \% \\
63 \% \\
84 \% \\
83 \% \\
78 \% \\
14 \% \\
17.4 \% \\
20 \%\end{array}$ & $\begin{array}{l}1.1 \% \\
0 \% \\
0 \% \\
2 \% \\
2 \% \\
32.5 \% \\
24 \% \\
23 \%\end{array}$ & $\begin{array}{l}18.3 \% \\
28 \% \\
16 \% \\
13 \% \\
13 \% \\
23.5 \% \\
2.2 \% \\
3 \%\end{array}$ \\
\hline
\end{tabular}

This table shows the difference between the birdfauna of the Aru- and Kei-islands very clearly. My figures agree rather well with those derived from the table given by von Berlepsch $^{9}$ ), who expresses the constitution of the birdfauna of the Aru-islands as follows: 112

1) Max Weber, Nova Guinea V, Livraison II. 1908, p. 201.

2) Max Weber, Zool. Anz. XXXII. 1907, p. 401.

3) De Beaufort, Zool. Anz. XXXVI. 1910, p. 249.

4) Max Weber, Abhandl. Senckenberg. Naturf. Gesellsch. XXXIV. 1911, p. 1.

5) On the birds of the Key and South-east Islands, Novit. Zoologicae VIII. 1901, p. 1

6) Jean Roux, Reptilien und Amphibien der Aru- und Kei-Inseln. Senckenb. Naturf. Gesellsch. XXXIII. 1910, p. 211.

7) Thomas Barbour. A contribution to the zoogeography of the east indian islands. Mem. Mus. Comp. Zool. Harvard Coll. XLIV. $\mathrm{n}^{2}$ 1. 1919

8) De Beaufort, Handelingen XIIIdc Nederl. Natuur- en Geneesk. Congres. 1911, p. 242.

9) Von Berlepsch. Abh. Senckenb. Naturf. Gesellsch. XXXIV. 1911, p. 55. 
species $(66 \%)$ occur also on New Guinea, $21(12 \%)$ are represented there by local races, 38 species $(22 \%), 11$ of which are endemic, do not occur on New Guinea. This would give on my table in the two first columns for the Aru-islands $6,4 \%$ in stead of $\% \%$ and $7 \%, 1 \%$ in stead of $78 \%$.

The difference between my results and those of von Berlepsch are mainly due to different conceptions of the value of some subspecies. As I pointed out in my paper quoted above, there is a great difference between the birdfauna of the 5 first islands in the table and the 3 following. The 5 first have a fauna of a mainly papuan character, the percentage of the species they have in common with New Guinea being $66.6,63,84,83$ and 79 , whereas western affinities are scarce or absent $(1.1 \%, 0 \%, 0 \%, 2 \%, 2 \%)$. Endemic species of Salawatti are unknown, and this island certainly remained longest connected with New Guinea. The occurrence here of a species of Zaglossus (Proechidna), while the genus is otherwise restricted to New Guinea, is of some significance in this respect. Although so very close to Salawatti, Batanta has a birdfauna $9 \%$ of which are endemic. None of these, however, are strictly endemic, but they are also found on Waigeu and nowhere else. This shows the close connection between Batanta and Waigeu, which islands have surely only been separated in recent times, long after the separation between them and Salawatti, which then probably still formed a part of New Guinea. The deep Pitt strait (strait Saguwin) between Batanta and Salawatti is of much older date than the shallow Dampier strait, scattered with reef, between Batanta and Waigeu. This is not expressed here for the first time, but has already been stated by Guillemard ${ }^{1}$ ), and with the same arguments taken from the birdfauna of these islands.

The number of endemic species of the birdfauna of Misol is only $2 \%, 83 \%$ of the species being also found on New Guinea. This shows that Misol too is nothing else but a part of that great island, separated in recent times. The papuan character of the birdfauna has already been stated by Rothschild and Hartert ${ }^{-2}$ ). It is noteworthy that the reptilian fauna does not show such a strong. affinity to that of New Guinea. Barbour ${ }^{3}$ ) has laid stress upon this fact, and pointed out that several oriental forms have been recorded from this island.

The distribution of the birds, shown in our table, made me conclude that a line, running from north to south westward of Waigeu and Misol, deflected here in south eastern direction and leaving Ceram to the west of it, and then running between the Kei- and Aru-islands to Australia, would show the probable northwestern outline of the australian continent in tertiary times. This line coincides with that of $200 \mathrm{M}$. depth on the chart, and an upheval of $200 \mathrm{M}$. of the sea-bottom would produce the old conditions, Waigeu, Batanta, Salawatti, Misol and the Aru-islands forming part of the mainland, which would be separated by sea from Halmahera, Ceram and the Kei-Islands. We have seen that the occurrence of Melanotaeniidae in the Aru-islands and Waigeu confirms this opinion. The freshwater of Salawatti, Batanta and Misol has not yet bien explored, but I think it probable, that Nelanotaeniidae will be found there.

We will now shortly consider the element of the fishfauna mentioned sub 2 above. This is formed by species belonging to true freshwater fish-families: Barbus maculatus, Rasbora argyrotaenia and elberti as members of the Cyprinidae, Ophiocephalus (Ophiocephalidae), Anabas scandens (Anabantidae) and Clarias.(Siluridae), although lastnamed genus belongs to a family, some of the members of which occur also in the sea. The species of Clarias however are restricted to freshwater, or at most descend rivers to their mouth. Aplocheilus javanicus and celebius may be mentioned here too. Although not restricted to freshwater, they form here the most eastern outskirts (Timor) of the family Cyprinodontidae and constitute an oriental element in the fauna of the islands where they occur.

There is communis opinio among zoogeographers as well as geologists that the Greater Sunda-islands formed part of the asiatic continent in tertiary times. The distribution of the

1) Guillemard, The Cruise of the Marchesa, vol. II. 1886, p. 270.

2) Rothschild and Hartert, Novitates zoologicae VIII. $\mathrm{n}^{\circ}$ 1. 1901, p. 56

3) Barbour, op. c. p. 40 and 41 . 
Cyprinidae and many other freshwater-fishfamilies have contributed to establish this opinion. Since Max Weber ${ }^{1}$ ) stated the occurrence of Cyprinidae on Lombok and showed that their distribution can no longer be maintained as an argument which the believers in the „line of Wallace" can bring forward, out of an ichthyological point of view the possibility may be considered that this tertiary asiatic continent was prolonged eastward in a peninsula, which later on broke into several islands.

The occurrence of Rasbora elberti and Clarias batrachus on Sumbawa, as mentioned by Popta, through which the boundary of the Cyprinidae and of this asiatic genus of Siluridae is even more shoven to the east, may lead us to suppose that this asiatic peninsula even reached so far as lastnamed island. However it is not my intention to consider this problem. here at length.

Anabas scandens and Ophiocephalus striatus are the only indian freshwater-fishes which extended their range east of the supposed tertiary asiatic continent. The probable reason why these, and these only of the many others which yet inhabit the rivers and lakes of the Greater Sunda-islands, were able to penetrate so far eastward, will be mentioned lower down. After exclusion of the australian element (Copidoglanis, Rhombatractus, Pseudomugil) and of the indian element (Barbus, Rasbora, Clarias, Ophiocephalus, Anabas, Aplocheilus) of our list, their remains a quantity of.species which form the group mentioned sub 1 on page 159 and which largely contributes to the freshwater-fauna of the islands now under consideration. In fact on many of them no others than these marine invaders are known to inhabit the freshwater. In the table I have noted the distribution of each genus. It will be seen that many of them are formed by species of genera. which are chiefly marine, e. g. Epinephelus, Gymnothorax, Tetrcoodon, and the occurrence of some species of these genera in freshwater may only be accidental and perhaps they had better been left out of the list, as many other species which have been found in estuaries and in the undercourse of rivers. could claim equal right to be recorded here (e. g. Hemirhumphus, several Carangidae, Gymnapistus niger, some Pleuronectidae etc.). They prove what has already been stated by Max Weber, that the invasion of marine species into the freshwater is still going on. On the other hand, the rest of the species mentioned in the list belong to genera, the members of which are chiefly to be found in freshwater and some of the species seem to have completely adopted themselves to this element e. g. species of Kuhlia, Eleotris, Gobius, while other genera seem to be completely restricted to freshwater as Agonostoma, Aeschrichthys, Toxotes, Sicyopterus, Sicyopus, Stiphodon, Rhiacichthys, or at most descend the rivers to the estuaries.

They all participate in the freshwater-fauna of these islands as well as of those to the west and east of them, some of the genera having a wide range. Many of the species are found here as well as to the west and east, inhabiting the rivers of Sumatra or even the asiatic continent as well as the brooks of many of the West Pacific islands. They form what. might be called the neutral shade of the freshwater-fishfauna of the islands of the Indo. pacific, obsolete on the Greater Sunda-islands by the strong asiatic colouring of the fishfarna. here, slightly altered on New Guinea and neighbouring islands by an australian tint and. coming into fullest development even in the Molucco islands, where they have not to compete with "true" freshwater-fishes.

Among the genera which occur here there are a few, which could be called endemic, as they are restricted to this part of the world. These genera are: Aeschrichthys, Sicyopus Stiphodon, Microsicydium and Rhiacichthys, possibly also Schismatogobius. Now it is noteworthy that the species of all these genera are particularly found in mountain streams. In the table given of the distribution of the fishes in the river Riuapa of Ceram (see page 155), it may be seen that species of Sicyopus, Stiphodon, Microsicydium, Rhiacichthys are chiefly or exclusively found in the higher parts of the streams. By their rounded ventral disk Sicyopus, Microsicydium and Stiphodon (as well as Sicyopterus) seem to be well suited to live at the.

1) Max Weber, Siboga-Exp. Introduction 1902, p. 16. - Der: Indo-australische Archipel und die Geschichte seinerTierwelt. Fischer. Jena. 1902, p. 26. 
bottom of rapidly llowing torrents and Rhiacichthys may even said to be especially adapted to such a mode of life. I must add, however, that Microsicydium has also been recorded from brackish water. As just these genera, which show a special predilection to torrents, are the only ones which seem to have originated here (with the exception of Aeschrichthys goldici, which has only twice been recorded, once from New Guinea and once from Timor, and which cannot be said to be specially adapted for the life in mountain streams, although the Timorspecimens came from an altitude of about $700 \mathrm{~m}$ ), one may be allowed to make the supposition that in times when the invasion into the freshwater of these islands began or in other words when these islands were formed themselves, the fishes found circumstances which favoured the adaption to torrent-life.

This means that these islands must have been small or at least narrow and mountainous and that they rose steeply out of the sea.

No lowland of great extent was present, and the rainwater falling on these islands was carried along rapidly flowing brooks to the sea and dit not find conditions favourable to assemble in lakes, marshes or ponds of any importance.

In these brooks the above-named genera developed out of marine Gobiidae. Only later on, when the streams had deposed the materials, carried from the mountains into lowland and a gently flowing undercourse was formed with ponds and marshes, a new invasion of marine forms took place; but this invasion was too recent to produce new forms. Thus may be explained why the lakes, ponds and undercourses of the rivers in the Molucco-islands do not posess any special fish-genera or even species (whereas such forms, dirived from marine invaders are present as well on the Greater Sunda-islands as on New Guinea e. g. Lycothrissa, Datnioides, the Melanotaeniidae etc.), while at the other hand such "endemic" forms are now found in the uppercourse of the rivers.

Narrow landbridges connecting Celebes with the Molucco's and New Guinea as well as with the Lesser Sunda-islands have been postulated to explain the fauna of this island by the Sarasins ${ }^{1}$ ), and van Kampen ${ }^{2}$ ), led by the distribution of the Amphibia, has pointed out that these landconnections must have been poor in freshwater. In this respect he draws the attention to the distribution of Anabas scandens and Ophiocephalus striatus as well as of Symbranchus bengalensis and Monopterus albus. All these species are able to stand drying up of their habitat or to live in mud, generally spoken they can manage to remain alive where not much water is available. This explains why they only among the many freshwater-fishes of the Great Sunda-islands, were able to penetrate eastward. This postulation of scantity of freshwater is quite in accordance with that to which I came above. I should only be inclined to add that the landbridges, which formed temporary connections between Java, Celebes, the Molucco's and New Guinea were not only narrow, but also steep, in other words, that the islands, which by their successive and various connection with each other formed these bridges, were not for instance low coral-islands, risen slightly above the sea level, but on the contrary were high and rising abruptly out of the sea.

1) P. \& F. Sarasin, Ueber die geologische Geschichte der Insel Celebes auf Grund der Thierverbreitung. Wiesbaden. 1901. 2) P. N. van Kampen, Nova Guinea IX. Livraison I. 1911, p. 46 and 47. 


\section{EXPLANATION OF PLATE II.}

Fig. 1. Rhombatractus catherinae de Bfrt. nat. size. River Rabiai, Waigeu.

Fig. 2. Schismatogobius bruynisi de Bfrt. $\times 1 \frac{1}{2}$. River Eme. Ceram.

Fig. 3. $\quad$ Sicyopus zosterophorum (Blkr.) $\times 1 \frac{1}{2}$. River Eme. Ceram.

Fig. 4. Stiphodon elegans (Steind.) $\sigma^{7} \times 1 \frac{1}{2}$. River Eme. Ceram:

Fig. 5. Stiphodon elegans (Steind.) o $\times 1 \frac{1}{2}$. River Eme. Ceram.

Fig. 6, \%. Eleotris hoedti Blkr., O', nat. size. River at Kajeli, Buru. 


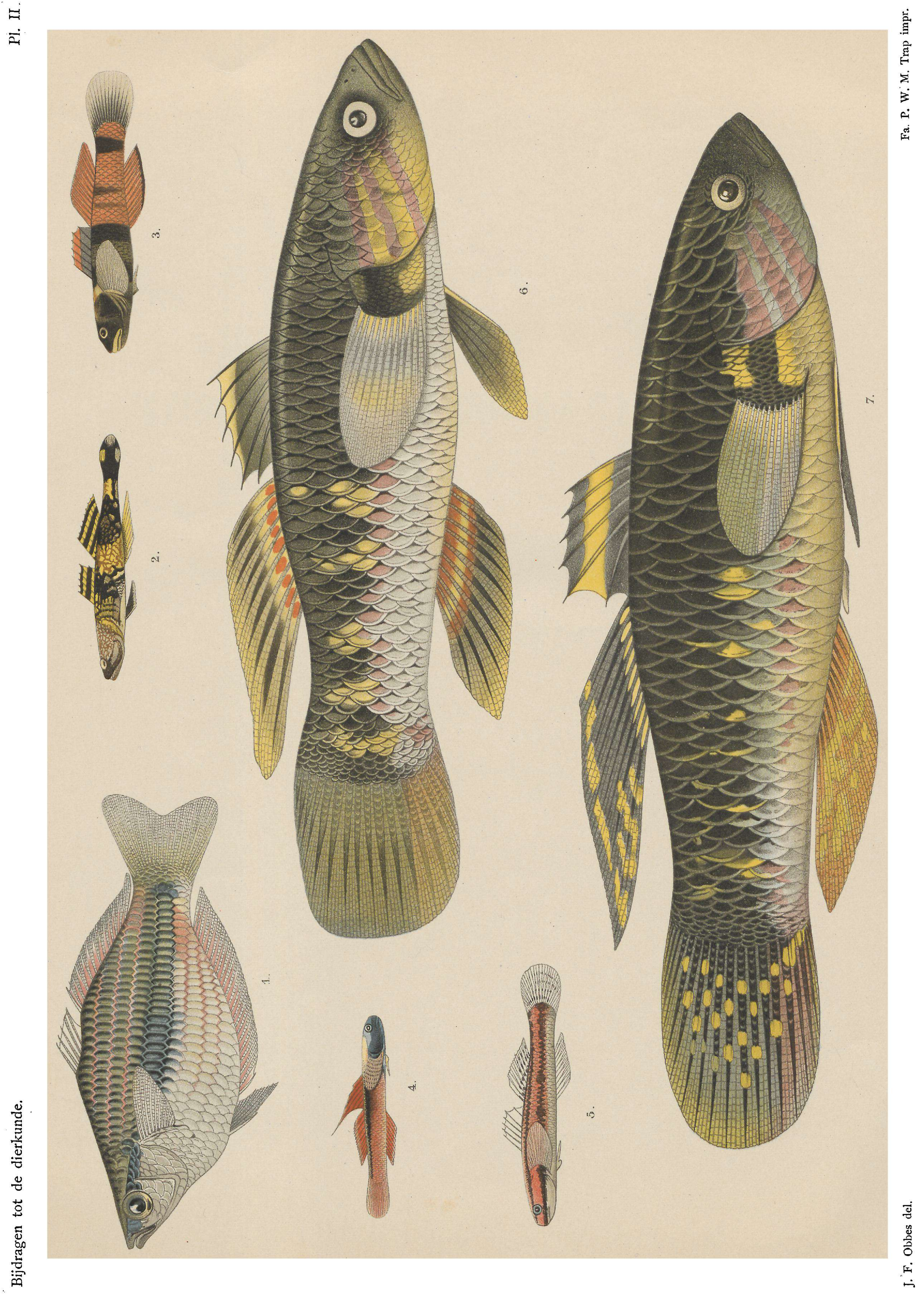

